\section{BUKU AJAR}

\section{METODOLOGI PENELITIAN DASAR}

\section{BIDANG PENDIDIKAN}

Mohammad Faizal Amir, M.Pd. Septi Budi Sartika, M.Pd.

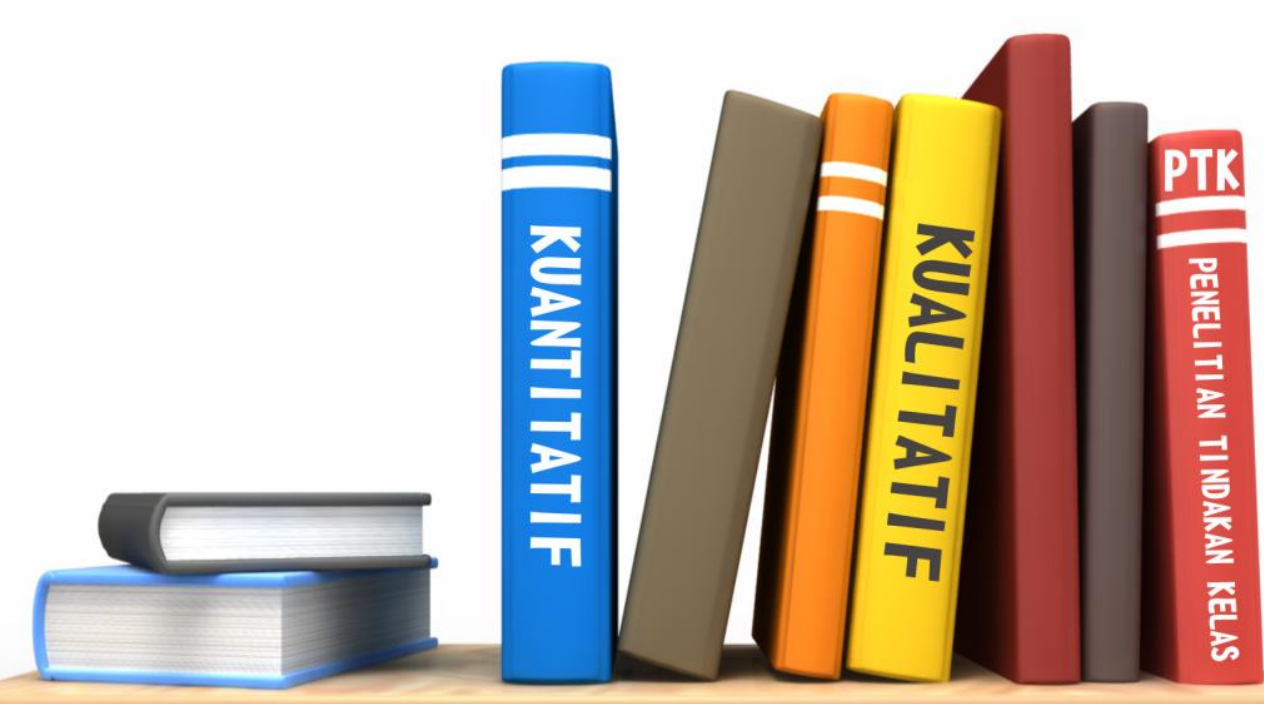

UNIVERSITAS MUHAMMADIYAH SIDOARJO 2017
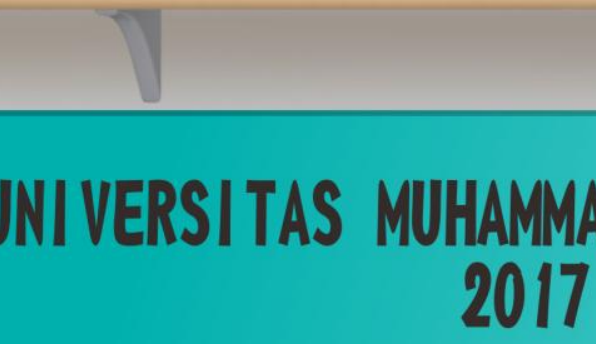

UMSIDA PRESS 


\title{
BUKU AJAR \\ METODOLOGI PENELITIAN DASAR \\ BIDANG PENDIDIKAN
}

\author{
Penulis \\ Mohammad Faizal Amir, M.Pd. \\ Septi Budi Sartika, M.Pd.

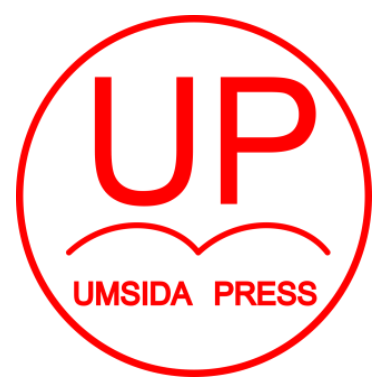 \\ Diterbitkan oleh \\ UMSIDA PRESS \\ Jl. Mojopahit 666 B Sidoarjo \\ ISBN: 978-979-3401-67-6 \\ Copyright@ 2017. \\ Authors \\ All rights reserved
}




\section{BUKU AJAR}

\section{METODOLOGI PENELITIAN DASAR}

\section{BIDANG PENDIDIKAN}

\section{Penulis :}

Mohammad Faizal Amir, M.Pd.

Septi Budi Sartika, M.Pd.

\section{ISBN :}

978-979-3401-67-6

\section{Editor :}

Septi Budi Sartika, M.Pd

M. Tanzil Multazam , S.H., M.Kn.

\section{Copy Editor :}

Fika Megawati, S.Pd., M.Pd.

\section{Design Sampul dan Tata Letak :}

Mochamad Nashrullah, S.Pd

\section{Penerbit :}

UMSIDA Press

\section{Redaksi :}

Universitas Muhammadiyah Sidoarjo

J1. Mojopahit No 666B

Sidoarjo, Jawa Timur

\section{Cetakan pertama, Agustus 2017}

(C) Hak cipta dilindungi undang-undang

Dilarang memperbanyak karya tulis ini dengan suatu apapun tanpa ijin tertulis dari penerbit. 


\section{KATA PENGANTAR}

Puji syukur kami panjatkan kehadirat Allah SWT, atas rahmat dan karunia-Nya Buku Ajar Metodologi Penelitian Dasar Bidang Pendidikan dapat diselesaikan dengan baik dan tanpa halangan yang berarti. Shalawat dan salam selalu kami sampaikan kepada junjungan Nabi Muhammad SAW.

Tim penulis mengucapkan terimakasih kepada:

1. Dr. Hidayatulloh, M.Si., Rektor UMSIDA yang memberikan kesempatan luas kepada tim penulis untuk berkarya dan menyumbangkan pikiran sehingga buku ajar ini terselesaikan.

2. Dr. Nur Efendi, M.Pd., Dekan Fakultas Keguruan dan IImu Pendidikan yang memberikan arahan dan motivasi kepada penulis dalam menyelesaikan buku ajar metodologi penelitian dasar bidang pendidikan ini.

3. Rekan-rekan dosen pengampu Mata Kuliah Metodologi Penelitian di FKIP UMSIDA yang telah berbagi pengalaman dalam mengampu mata kuliah tersebut.

Saran dan kritik sangat penulis harapkan untuk mewujudkan buku ajar Metodologi Penelitian Dasar Bidang Pendidikan yang lebih baik dan tentunya sesuai dengan amanat peraturan yang berlaku. Terimakasih.

Penulis 


\section{DAFTAR ISI}

KATA PENGANTAR

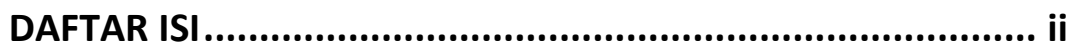

\section{BAB I PENDAHULUAN}
A. Hakikat Penelitian.
.1
B. Fungsi Metodologi Penelitian ...............................................
C. Macam-Macam Penelitian Pendidikan ....................................

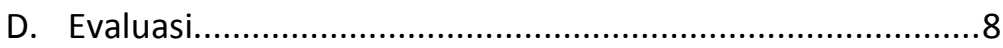

BAB II METODOLOGI PENELITIAN KUANTITATIF
A. Paradigma Penelitian Kuantitatif. .9
B. Penelitian Tunggal .......................................................12

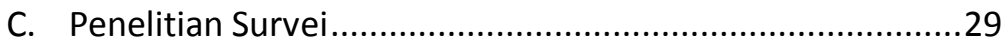
D. Penelitian Korelasi ..............................................................
E. Penelitian Kausal Komparatif ............................................45
F. Penelitian Eksperimen ...................................................49

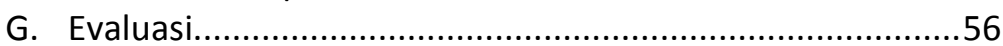

BAB III METODOLOGI PENELITIAN KUALITATIF
A. Paradigma Penelitian Kualitatif .58
B. Karakteristik Penelitian Kualitatif 62
C. Rumusan Masalah dan Judul Penelitian Kualitatif .68
D. Analisis Penelitian Kualitatif .69
E. Latihan Membuat Penelitian Kualitatif..... .94

BAB IV METODOLOGI PENELITIAN TINDAKAN KELAS (PTK)

A. Paradigma PTK .........................................................98

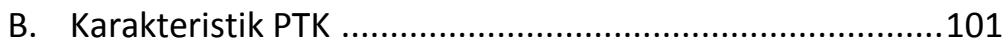

C. Mengidentifikasi Macam PTK ……………………..........107

D. Praktik Melakukan PTK ..................................................111

E. Contoh Penyusunan dan Laporan PTK..............................118

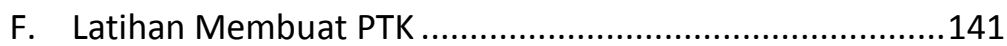

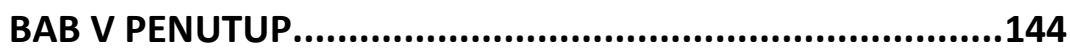

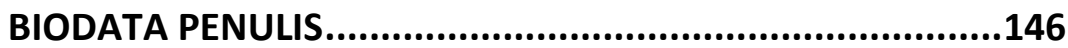


BATANG TUBUH DAN

SUB-CAPAIAN PEMBELAJARAN MATA KULIAH

\begin{tabular}{|c|c|}
\hline BAB & Sub-Capaian Pembelajaran Mata Kuliah \\
\hline BAB I PENDAHULUAN & $\begin{array}{l}\text { 1. Memahami hakikat metodologi penelitian } \\
\text { pendidikan. } \\
\text { 2. Memahami fungsi metodologi penelitian } \\
\text { pendidikan. } \\
\text { 3. Mengkategorikan macam-macam metodologi } \\
\text { penelitian dasar bidang pendidikan. } \\
\text { 4. Menganalisis hakikat metodologi penelitian } \\
\text { pendidikan melalui evaluasi. }\end{array}$ \\
\hline $\begin{array}{l}\text { BAB II METODOLOGI } \\
\text { PENELITIAN } \\
\text { KUANTITATIF }\end{array}$ & $\begin{array}{l}\text { 1. Memahami paradigma metodologi penelitian } \\
\text { kuantitatif. } \\
\text { 2. Mengidentifikasi macam penelitian } \\
\text { kuantitatif. } \\
\text { 3. Memahami desain penelitian kuantitatif } \\
\text { dalam permasalahan bidang pendidikan. } \\
\text { 4. Menganalisis desain penelitian kuantitatif } \\
\text { melalui evaluasi. }\end{array}$ \\
\hline $\begin{array}{l}\text { BAB III METODOLOGI } \\
\text { PENELITIAN KUALITATIF }\end{array}$ & $\begin{array}{l}\text { 1. Memahami paradigma metodologi penelitian } \\
\text { kualitatif. } \\
\text { 2. Mengidentifikasi karakteristik penelitian } \\
\text { kualitatif. } \\
\text { 3. Mengidentifikasi rumusan masalah dan judul } \\
\text { penelitian kualitatif. } \\
\text { 4. Menganalisis desain penelitian kualitatif. } \\
\text { 5. Merancang penelitian kualitatif. }\end{array}$ \\
\hline $\begin{array}{l}\text { BAB IV METODOLOGI } \\
\text { PENELITIAN TINDAKAN } \\
\text { KELAS (PTK) }\end{array}$ & $\begin{array}{l}\text { 1. Memahami paradigma metodologi penelitian } \\
\text { tindakan kelas. } \\
\text { 2. Mengidentifikasi karakteristik penelitian } \\
\text { tindakan kelas. } \\
\text { 3. Mengidentifikasi macam penelitian tindakan } \\
\text { kelas. } \\
\text { 4. Mempraktekkan penelitian tindakan kelas. } \\
\text { 5. Merancang penelitian tindakan kelas. }\end{array}$ \\
\hline BAB V PENUTUP & $\begin{array}{l}\text { Menyimpulkan macam metodologi penelitian } \\
\text { dasar bidang pendidikan. }\end{array}$ \\
\hline
\end{tabular}




\section{BAB I}

\section{PENDAHULUAN}

\section{A. Hakikat Penelitian}

Rasa ingin tahu (curiousity) merupakan sifat dasar yang dimiliki manusia. Dengan adanya rasa ingin tahu, mendorong manusia memperoleh pengetahuan. Setiap manusia dianugerahi akal dan pikiran untuk memperoleh pengetahuan, baik berupa fakta, konsep, prinsip atau hukum. Pengetahuan dapat diperoleh dengan adanya pengalaman melalui interaksi dengan sesamanya maupun dengan lingkungannya menggunakan panca indra. Terdapat 3 jenis pengetahuan yang dimiliki oleh manusia yaitu: (1) logika yang mampu membedakan benar dan salah; (2) etika yang mampu membedakan baik dan buruk; serta (3) estetika yang mampu membedakan indah dan jelek.

Salah satu pengetahuan yang dimiliki manusia adalah pengetahuan ilmiah yang lebih kita kenal dengan ilmu. IImu merupakan bagian pengetahuan, namun tidak semua pengetahuan bisa dikatakan sebagai ilmu. Ilmu merupakan pengetahuan yang didasari oleh koherensi dan korespondensi. Koherensi merupakan pernyataan yang dikatakan benar jika pernyataan tersebut konsisten dengan pernyataan sebelumnya. Koherensi dalam pengetahuan diperoleh melalui pendekatan logis atau berpikir secara 
rasional. Korespondensi merupakan pernyataan dikatakan benar jika pernyataan didasarkan atas fakta atau realita. Koherensi dalam pengetahuan diperoleh melalui pendekatan empiris atau bertolak dari fakta. Dengan demikian, kebenaran ilmu harus dapat dideskripsikan secara rasional dan dibuktikan secara empiris.

Koherensi dan korespondensi mendasari bagaimana ilmu diperoleh telah melahirkan cara mendapatkan kebenaran ilmiah. Proses untuk mendapatkan ilmu agar memiliki nilai kebenaran harus dilandasai oleh cara berpikir yang rasional berdasarkan logika dan berpikir empiris berdasarkan fakta. Salah satu cara untuk mendapatkan ilmu adalah melalui penelitian. Penelitian sebagai upaya untuk memperoleh kebenaran harus didasari oleh proses berpikir ilmiah yang dituangkan dalam metode ilmiah. Metode ilmiah adalah kerangka landasan terciptanya pengetahuan ilmiah. Penelitian yang dilakukan menggunakan metode ilmiah yang mengandung 2 (dua) unsur penting yaitu pengamatan (observation) dan penalaran (reasoning). Metode ilmiah didasari oleh pemikiran bahwa apabila suatu pernyataan ingin diterima sebagai suatu kebenaran maka pernyataan tersebut harus dapat diverifikasi atau diuji kebenarannya secara empiris (berdasarkan fakta).

Metode secara etimologi berasal dari bahasa Yunani yaitu methodos yang berarti cara atau jalan menuju suatu 
jalan. Secara terminologi, metode adalah kegiatan ilmiah yang berkaitan dengan cara kerja (sistematis) untuk memahami suatu atau objek penelitian, sebagai upaya untuk menemukan jawaban yang dapat dipertanggungjawabkan secara ilmiah dan termasuk keabsahannya. Metodologi atau science of methods adalah ilmu yang membicarakan jalan dan cara, sedangkan metode adalah cara kerja untuk dapat memahami objek penelitian dengan langkah-langkah sistematis. Kumpulan metode disebut metodik sedangkan ilmu yang mempelajari metode-metode disebut metodologi.

Penelitian adalah kegiatan ilmiah yang berkaitan dengan analisis dan konstruksi yang dilakukan secara metodologis, sistematis, dan konsisten. Sistem dan metode yang dipergunakan untuk memperoleh informasi atau bahan materi suatu pengetahuan ilmiah yang disebut dengan metodologi ilmiah. Jadi, metode penelitian adalah cara kerja untuk dapat memahami objek penelitian. Penelitian dapat didefinisikan sebagai upaya mencari jawaban yang benar atas suatu masalah berdasarkan logika dan didukung oleh fakta empiris. Sehingga, penelitian adalah kegiatan yang dilakukan secara sistematis melalui proses pengumpulan data, pengolah data, serta penarikan kesimpulan berdasarkan data menggunakan metode dan teknik tertentu.

Penelitian merupakan bentuk kegiatan yang menggunakan 2 (dua) hal yaitu logika berpikir dan data atau 
informasi yang dikumpulkan secara empiris. Logika berpikir tercermin dalam langkah-langkah sistematis mulai dari pengumpulan, pengolahan, analisis, penafsiran dan pengujian data sampai diperolehnya kesimpulan. Informasi dikatakan empiris jika sumber data mengambarkan fakta yang terjadi bukan sekedar pemikiran atau rekayasa peneliti. Penelitian menggabungkan cara berpikir rasional yang didasari oleh logika/ penalaran dan cara berpikir empiris yang didasari oleh fakta/ realita. Penjelasan tersebut dapat dikatakan bahwa penelitian adalah langkah sistematis dalam upaya menyelesaikan masalah.

Metodologi penelitian adalah strategi menyeluruh untuk menemukan atau memperoleh data yang diperlukan. Metode penelitian harus dibedakan dari teknik pengumpulan data yaitu teknik yang lebih khusus untuk memperoleh data. Metodologi penelitian dasar bidang pendidikan meliputi 1) penelitian kuantitatif, 2) penelitian kualitatif, dan 3) penelitian tindakan kelas.

\section{B. Fungsi Metodologi Penelitian}

Penelitian merupakan pembuktian dari rasa ingin tahu manusia terhadap masalah dengan melakukan tindakan misalnya: memeriksa, menelaah, mempelajari dengan cermat/ sungguh-sungguh, sehingga diperoleh suatu temuan berupa kebenaran, jawaban, atau pengembangan ilmu 
pengetahuan. Terkait dengan ilmu pengetahuan, dapat dikemukakan 3 (tiga) tujuan umum penelitian yaitu:

1. Tujuan Eksploratif, penelitian dilaksanakan untuk menemukan ilmu pengetahuan yang baru dalam bidang tertentu. IImu yang diperoleh melalui penelitian betulbetul baru belum pernah diketahui sebelumnya. Misalnya, suatu penelitian telah menghasilkan kriteria level-level kreativitas dalam menyelesaikan masalah IPA. Contoh lainnya adalah penelitian yang menghasilkan suatu metode baru pembelajaran matematika yang menyenangkan dan inovatif sesuai dengan perkembangan IPTEK dan tuntutan Abad-21.

2. Tujuan Verifikatif, penelitian dilaksanakan untuk menguji kebenaran dari ilmu pengetahuan yang telah ada. Data penelitian yang diperoleh digunakan untuk membuktikan adanya keraguan terhadap informasi atau ilmu pengetahuan tertentu. Misalnya, suatu penelitian dilakukan untuk membuktikan adanya pengaruh motivasi belajar dan hasil belajar pada mata pelajaran IPA. Contoh lainnya adalah penelitian yang dilakukan untuk menguji efektivitas model pembelajaran yang telah dikembangkan tertentu terhadap keterampilan Abad-21.

3. Tujuan Pengembangan, penelitian dilaksanakan untuk mengembangkan ilmu pengetahuan yang telah ada. Penelitian dilakukan untuk mengembangkan atau 
memperdalam ilmu pegetahuan yang telah ada. Misalnya, penelitian tentang implementasi model inquiry dalam pembelajaran IPS yang sebelumnya telah digunakan dalam pembelajaran IPA. Contoh lainnya adalah pengembangan perangkat pembelajaran berorientasi model pembelajaran pemaknaan.

Metode Ilmiah merupakan suatu cara sistematis yang digunakan oleh para ilmuwan untuk menyelesaikan masalah. Metode ini menggunakan langkah-langkah yang sistematis, teratur, dan terkontrol. Supaya metode yang digunakan dalam penelitian disebut metode ilmiah, maka metode tersebut harus mempunyai kriteria sebagai berikut: 1) berdasarkan fakta, 2) bebas dari prasangka, 3) menggunakan prinsip-prinsip analisis, 4) menggunakan hipotesis, 5) menggunakan ukuran objektif, dan 6) menggunakan teknik kuantifikasi.

C. Macam-macam Metodologi Penelitian Dasar Bidang Pendidikan

Adapun macam-macam metodologi penelitian dasar bidang pendidikan sebagai berikut:

1. Penelitian Kuantitatif (Quantitative Research)

Penelitian kuantitatif adalah penelitian ilmiah yang sistematis terhadap bagian-bagian dan fenomena serta hubungan-hubungannya. Tujuan penelitian kuantitatif 
untuk mengembangkan dan menggunakan model-model matematis (statistika), teori-teori, hipotesis, yang berkaitan dengan fenomena yang terjadi. Ciri-ciri kuantitatif meliputi teori, hipotesis, adanya perlakuan, pengamatan empiris, analisis data dengan statistika.

2. Penelitian Kualitatif (Qualitative Research)

Penelitian kualitatif berangkat dari filsafat ilmu yang mencari esensi segala sesuatu. Berbeda dengan penelitian kuantitatif, yang berangkat dari asumsi adanya normalitas, dan kebenaran dicari dari rerata normalitas frekuensi atau rerata keragaman berbagai sesuatu serta mencari kebenaran lewat sampel acak atas sampel itu representatif terhadap populasinya. Pada penelitian kualitatif, mencari kebenaran melalui kasus yang menampilkan esensi yang dicari.

3. Penelitian Tindakan (Actions Research)

Penelitian tindakan merupakan kajian tentang situasi sosial yang diarahkan untuk meningkatkan kualitas. Secara keseluruhan penelitian tindakan meliputi proses telaah/ analisis, diagnosis, perencanaan, pelaksanaan, monitoring, dan efek yang terkait dengan evaluasi diri dan perkembangan profesional. Penelitian tindakan merupakan bentuk refleksi diri kolektif yang dilakukan oleh para peserta dalam situasi sosial untuk meningkatkan penalaran dan keadilan. Penelitian 
tindakan dalam bidang pendidikan disebut sebagai Penelitian Tindakan Kelas (PTK) merupakan refleksi diri yang dilakukan oleh para partisipan (guru, siswa, dan kepala sekolah) dalam situasi pendidikan untuk memperbaiki dan meningkatkan rasionalitas dan kebenaran mengenai praktik pendidikan yang dilakukan sendiri, pengertian mengenai praktik itu sendiri, dan situasi tempat praktiknya. Jadi, PTK merupakan penelitian yang diarahkan pada adanya kesadaran diri para pengajar untuk mengevaluasi diri, merefleksi diri, dan berani bertindak dan berpikir kritis guna meningkatkan profesionalitas dalam rangka meningkatkan kualitas pendidikan.

Ketiga macam penelitian tersebut akan dibahas satu-persatu dalam bab selanjutnya secara khusus berikut contoh dan evaluasinya.

\section{Evaluasi}

1. Rasa ingin tahu akan melahirkan suatu pengetahuan, bagaimana proses terciptanya pengetahuan tersebut?

2. Dengan adanya penelitian maka akan lahir pengetahuan, apa makna penelitian itu? 


\section{BAB II}

\section{PENELITIAN KUANTITATIF}

\section{A. Paradigma Metodologi Penelitian Kuantitatif}

Paradigma kuantitatif merupakan suatu pendekatan penelitian yang dibangun berdasarkan filsafat positivisme. Positivisme merupakan aliran filsafat yang menolak unsur metafisis dan teologik dari realitas sosial, karena penolakannya, positivisme dianggap sebagai sebuah varians dari materialisme (bila yang terakhir ini dikontraskan dengan Idealisme).

Dalam penelitian kuantitatif, bahwa satu-satunya pengetahuan (knowledge) yang valid adalah ilmu pengetahuan (science), di mana pengetahuan yang berawal dan didasarkan pada pengalaman (experience) yang tertangkap lewat panca indra yang diolah nalar (reason). Secara epistemologis, dalam penelitian kuantitatif diterima suatu paradigma, bahwa sumber pengetahuan paling utama adalah fakta yang sudah pernah terjadi, dan lebih khusus lagi hal-hal yang dapat ditangkap panca indra (exposed to sensory experience). Hal ini sekaligus mengindikasikan, bahwa secara ontologis, objek studi penelitian kuantitatif adalah fenomena dan hubungan-hubungan umum antara fenomena-fenomena (general relations between phenomena). Yang dimaksud dengan fenomena adalah sejalan dengan prinsip sensory 
experience yang terbatas pada external appearance given in sense perception. Karena pengetahuan itu bersumber dari fakta yang diperoleh melalui panca indra, maka ilmu pengetahuan harus didasarkan pada eksperimen, induksi, dan observasi.

Pandangan kuantitatif terhadap fakta, dalam penelitian kuantitatif diyakini sejumlah asumsi sebagai dasar otologisnya dalam melihat fakta atau gejala. Asumsi-asumsi dimaksud adalah; (1) objek-objek tertentu mempunyai keserupaan satu sama lain, baik bentuk, struktur, sifat maupun dimensi lainnya; (2) suatu benda atau keadaan tidak mengalami perubahan dalam jangka waktu tertentu; dan (3) suatu gejala bukan merupakan suatu kejadian yang bersifat kebetulan, melainkan merupakan akibat dari faktor-faktor yang mempengaruhinya. Jadi, diyakini adanya determinisme atau proses sebab-akibat (causalitas).

Sejalan dengan penjelasan di atas, secara epistemologi, paradigma kuantitatif berpandangan bahwa sumber ilmu terdiri dari 2 (dua), yaitu pemikiran rasional data empiris. Ukuran kebenaran terletak pada koherensi dan korespondensi. Koheren berarti sesuai dengan teori-teori terdahulu, serta koresponden berarti sesuai dengan kenyataan empiris. Kerangka pengembangan ilmu dimulai dari proses perumusan hipotesis yang deduksi dari teori, kemudian diuji kebenarannya melalui verifikasi untuk 
diproses lebih lanjut secara induktif menuju perumusan teori baru. Jadi, secara epistemologis, pengembangan ilmu berputar mengikuti siklus: logico, hypothetico, verifikative.

Dalam metode kuantitatif, terdapat paradigma bahwa dalam setiap peristiwa sosial mengandung elemen-elemen tertentu yang berbeda-beda dan dapat berubah. Elemenelemen disebut dengan variabel. Variabel dari setiap peristiwa, baik yang melekat maupun yang mempengaruhi/ dipengaruhi, dimungkinkan menangkap seluruh variabel secara keseluruhan. Berdasarkan hal tersebut, penelitian kuantitatif ditekankan agar objek penelitian diarahkan pada variabel-variabel tertentu yang dinilai paling relevan. Jadi, paradigma kuantitatif cenderung pada pendekatan partikularistis.

Lebih khusus mengenai metode analisis dan prinsip pengambilan kesimpulan, menjelaskan paradigma kuantitatif dari 2 (dua) aspek penting, yaitu: bahwa penelitian kuantitatif menggunakan enumerative induction dan cenderung membuat generalisasi (generalization). Penekanan analisis data dari pendekatan enumerative induction adalah perhitungan secara kuantitatif, mulai dari frekuensi sampai analisis statistika. Generalisasi adalah pemberlakuan hasil temuan dari sampel terhadap populasi, karena dalam paradigma kuantitatif terdapat asumsi mengenai adanya 
"keserupaan" antara objek-objek tertentu, maka generalisasi juga dapat didefinisikan sebagai universalisasi.

Menurul Fraenkel et al (2012), penelitian kuantitatif terbagi menjadi lima (5) macam, yaitu 1) penelitian tunggal (single-subject research), 2) penelitian survei (survey research), 3) penelitian korelasi (correlational research), 4) penelitian kausal komparatif (causal-comparative research), dan 5) penelitian eksperimen (experiment research).

\section{B. Penelitian Tunggal (Single-Subject Research)}

1. Karakteristik Penelitian Tunggal

Suatu penelitian, terkadang tidak cukup untuk membentuk kelompok, sebagai contoh peneliti akan meneliti anak yang berkebutuhan khusus seperti menderita buta, bisu, atau bisu dan tuli karena jumlah anak tersebut tergolong sedikit. Hal inilah yang membuat peneliti mengalami kesulitan untuk membentuk kelompok, selanjutnya akan diamati secara detail.

Penelitian tunggal merupakan adaptasi dari desain time-series pada penelitian eksperimen. Perbedaan terletak pada jumlah data yang diperoleh dan dianalisis pada tunggal pada satu periode. Pada desain penelitian tunggal pengukuran variabel terikat atau subjek perilaku dilakukan berulang-ulang dengan periode tertentu misalnya per jam, per hari, atau per minggu agar 
mempunyai validitas internal yang tinggi maka desain tersebut harus memperhatikan pengukuran yang reliabel, berulang-ulang, dengan deskripsi kondisi, baseline, kondisi perlakuan, rentang dan stabilitas yang relatif sama serta variabel yang diubah hanya satu. Penelitian ini digunakan untuk meneliti perubahan tingkah laku individu setelah diberikan perlakuan atau perlakuan. Desain ini banyak digunakan pada pendidikan luar biasa.

Penelitian tunggal memiliki 5 karakteristik, yaitu:

a. Pengukuran dapat diandalkan/ terpercaya

Desain ini melibatkan langkah-langkah beberapa perilaku, maka instrumentasi harus dapat diandalkan. Kondisi untuk pengumpulan data, seperti waktu dan lokasi harus standar, dan pengamat perlu dilatih. Keajegan dalam pengukuran ini sangat penting dalam transisi sebelum dan setelah perlakuan.

b. Pengukuran berulang

Perilaku yang sama diukur berkelanjutan. Langkah ini berbeda dari sebagian besar desain penelitian eksperimen lainnya, di mana variabel dependen diukur hanya sekali. Tindakan berulang diperlukan untuk mendapatkan pola yang jelas atau keajegan dalam perilaku dari waktu ke waktu. Desain ini mirip dengan penelitian time-series, yang menyelidiki kelompok bukan individu dan tidak memberikan 
untuk kembali ke kondisi yang ada sebelum perlakuan dilaksanakan.

C. Deskripsi kondisi

Merupakan deskripsi yang jelas dan rinci dari kondisi pengukuran dan sifat perlakuan yang dibutuhkan untuk memperkuat validitas internal dan eksternal.

d. Kondisi awal dan perlakuan kondisi

Penelitian tunggal melibatkan setidaknya satu dasar dan satu syarat perlakuan. Kondisi awal mengacu pada periode waktu di mana perilaku sasaran (variabel dependen) diamati dan dicatat tanpa perlakuan khusus. Perilaku dasar menyediakan kerangka acuan terhadap perilaku masa depan yang dibandingkan. Kondisi awal juga dapat merujuk ke periode waktu setelah perlakuan di mana kondisi sesuai dengan apa adanya. Kondisi perlakuan adalah periode waktu di mana manipulasi eksperimental dilakukan dan perilaku sasaran terus diamati dan dicatat.

e. tunggal

Selama penelitian tunggal beberapa penelitian dua variabel berubah bersama selama kondisi perlakuan yang sama. Ini adalah interaksi dalam penelitian tunggal. 
2. Desain Satu

Peneliti tunggal menggunakan grafik garis untuk menampilkan data dan mengilustrasikan pengaruh dari perlakuan atau perlakuan, seperti Gambar 2.1. Variabel dependen diletakkan pada sumbu vertikal (sumbu-y) dan sumbu $x$ mengindikasikan waktu seperti sesi, hari, minggu, bulan. Penjelasan mengenai kondisi yang terlibat dalam penelitian ini adalah yang tercantum tepat di atas grafik. Kondisi pertama biasanya disebut kondisi awal, diikuti oleh perlakuan/ variabel bebas. Garis kondisi mengindikasikan ketika kondisi telah berubah. Titik-titik bulat adalah titik data. Data tersebut mewakili berbagai data yang dikumpulkan selama penelitian. Titik-titik data dihubungkan untuk mengilustrasikan kecenderungan data.

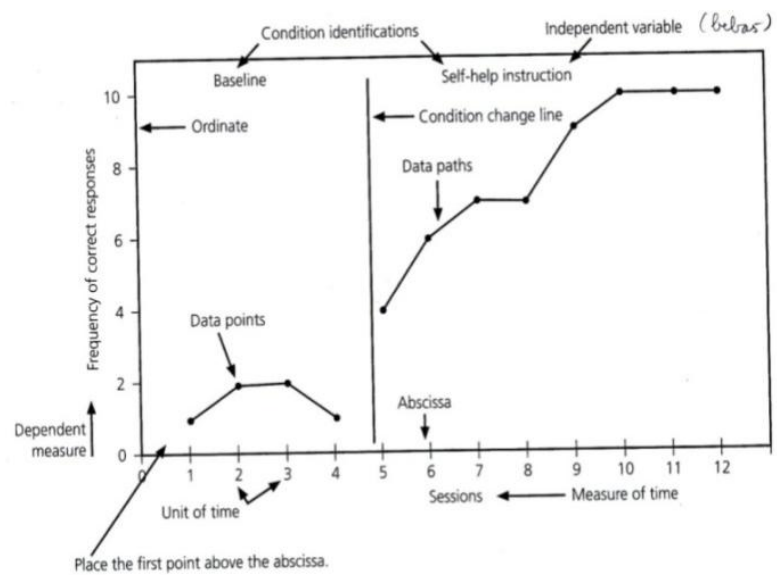

Percentage of correct responses across baseline and self-help conditions

Gambar 2.1 Grafik Tunggal 
a. Desain A-B

Pada desain A-B dasarnya adalah untuk mengumpulkan data pada yang sama, beroperasi pada kontrolnya, di bawah dua kondisi atau fase. Kondisi pertama adalah kondisi sebelum perlakuan, disebut dengan kondisi awal, dan diberi nama A. Selama periode kondisi awal, dinilai untuk beberapa sesi sampai menunjukkan perilaku yang khas. Kondisi awal sangat penting dalam penelitian tunggal karena merupakan perkiraan terbaik apa yang terjadi jika perlakuan tidak ada. Setelah kondisi awal ditetapkan diberi nama $A$, selanjutnya diberikan perlakuan diberi nama $B$, dikenakan selama periode tertentu.

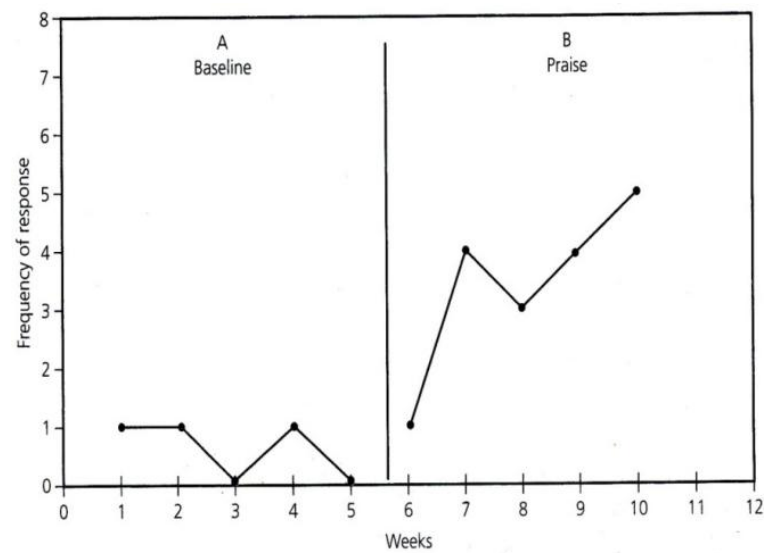

Frequency of response across baseline and praise conditions

Gambar 2.2 Desain A-B

Gambar 2.2 mengilustrasikan desain A-B, dapat dilihat 5 pengukuran sebelum perlakuan dan 5 
pengukuran selama perlakuan. Berdasarkan gambar 2.2, tampak bahwa perlakuan efektif, adanya peningkatan jumlah respon yang mencolok. Seperti halnya dalam one-shot case study, peneliti tidak mengetahui apakah perilaku yang terjadi disebabkan oleh perlakuan yang diberikan. Hal Ini mungkin disebabkan oleh beberapa variabel lain atau perubahan terjadi secara alamiah tanpa adanya perlakuan. Jadi, desain A-B gagal untuk mengendalikan berbagai ancaman validitas internal, itu tidak menentukan efek variabel bebas pada variabel terikat/ hasil, sementara mengesampingkan kemungkinan efek dari variabel ekstra. Pada desain A-B ini tidak ada replikasi (pengulangan) pengukuran di mana fase kondisi awal (A) dan perlakuan (B) masing-masing dilakukan hanya sekali untuk yang sama. Oleh karena itu, dengan desain ini tidak dapat disimpulkan atau tidak ada jaminan bahwa perubahan pada subjek disebabkan semata-mata oleh variabel bebas (perlakuan). Dengan kata lain karena tidak ada pengukuran ulang pada fase kondisi awal maupun fase perlakuan sehingga tidak bisa membandingkan masing-masing kondisi tersebut. Dengan demikian tidak dapat dipastikan adanya pengaruh perlakuan terhadap variabel terikat, sehingga dimungkinkan perubahan pada subjek juga dipengaruhi 
oleh faktor atau variabel lain yang tidak terkontrol. Faktor-faktor tersebut bisa terjadi karena faktor alamiah misalnya faktor kematangan. Untuk meningkatkan validitas penelitian menggunakan desain A-B, ada beberapa hal yang perlu mendapat perhatian yaitu:

1) Mendefinisikan subjek sebagai perilaku yang dapat diukur secara akurat.

2) Melaksanakan pengukuran dan pencatatan data pada kondisi kondisi awal (A) secara kontinyu sekurang-kurangnya 3 atau 5 kali (sampai trend dan level data diketahui secara jelas).

3) Memberikan perlakuan (B) setelah kondisi kondisi awal stabil.

4) Melakukan pengukuran subjek pada kondisi perlakuan (B) secara kontinyu selama periode waktu tertentu sampai trend dan level data menjadi stabil.

b. Desain A-B-A

Ketika menggunakan desain A-B-A (kadang disebut desain pembalikan), peneliti hanya menambahkan kondisi awal. Jika perilaku berbeda selama waktu perlakuan daripada waktu kondisi awal, merupakan bukti yang kuat bahwa perlakuan efektif. Desain A-B-A ditunjukkan pada Gambar 2.3: 


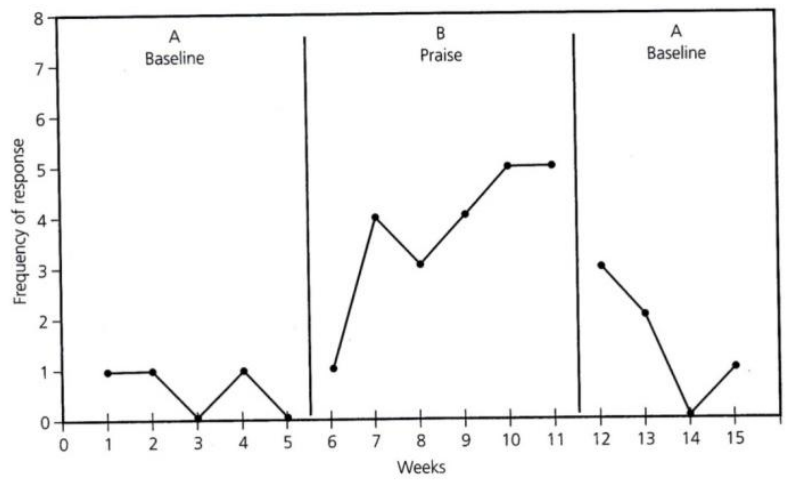

Gambar 2.3 Desain A-B-A

Desain A-B-A merupakan salah satu pengembangan dari desain dasar $A-B$, desain $A-B-A$ ini menunjukkan adanya hubungan sebab akibat antara variabel terikat dan variabel bebas. Prosedur dasarnya tidak banyak berbeda dengan desain A-B, hanya saja telah ada pengulangan fase kondisi awal. Mula-mula subjek diukur secara kontinyu pada kondisi awal (A1) dengan periode waktu tertentu kemudian diberikan perlakuan (B). Berbeda dengan desain A-B, pada desain A-B-A setelah pengukuran perlakuan (B) maka pengukuran pada kondisi awal kedua (A2) diberikan. Penambahan kondisi awal yang kedua (A2) ini dimaksudkan sebagai kontrol untuk fase perlakuan sehingga memungkinkan untuk menarik kesimpulan adanya hubungan fungsional antara variabel bebas dan variabel terikat. Penurunan ancaman validitas internal 
merupakan keuntungan dari desain A-B-A ini. Namun, ada yang merugikan dalam desain ini yaitu meninggalkan dalam kondisi awal A2. Banyak peneliti merasa tidak nyaman untuk mengakhiri penelitian jenis ini tanpa adanya peningkatan. Hasilnya, desain ini diperluas menjadi desain A-B-A-B.

c. Desain A-B-A-B

Dalam desain A-B-A-B, 2 (dua) kondisi awal dikombinasikan dengan dua perlakuan. Hal ini memperkuat kesimpulan tentang efektivitas dari perlakuan. Pada kenyataannya, perlakuan kedua dapat diperpanjang tanpa batas waktu jika peneliti menginginkannya. Jika perilaku sama selama ke dua perlakuan tersebut, dan lebih baik dari kedua kondisi awal, kemungkinan variabel lain yang menyebabkan perubahan dapat dikurangi secara tajam. Desain A-B-AB ditunjukkan pada Gambar 2.4 di bawah ini.

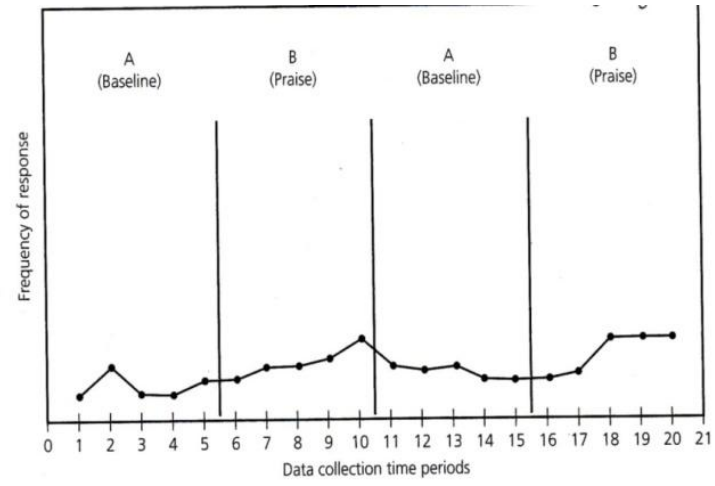

Gambar 2.4 Desain A-B-A-B 
Sebuah kondisi awal yang jelas telah ditetapkan, diikuti oleh peningkatan respon selama perlakuan, diikuti oleh penurunan respon ketika perlakuan dihentikan, diikuti oleh peningkatan respon segera sesudah perlakuan. Pola ini cukup memberikan bukti kuat bahwa peningkatan tersebut akibat perlakuan daripada faktor lain misalnya sejarah, kematangan atau sesuatu yang bertanggungjawab untuk perbaikan. Meskipun bukti-bukti seperti yang ditunjukkan pada Gambar 2.4 akan dianggap sebagai argumen yang kuat untuk sebab-akibat, kita harus menyadari bahwa desain A-B-A dan A-B-A-B memiliki keterbatasan: kemungkinan bias kolektor data (individu yang memberikan perlakuan biasanya juga sebagai pengumpul data) dan kemungkinan pengaruh instrumentasi (kebutuhan untuk jumlah waktu yang lama dari periode waktu pengumpulan data) dapat menyebabkan perubahan dalam kondisi dari pengumpulan data.

Desain A-B-A-B menunjukkan adanya kontrol terhadap variabel bebas yang lebih kuat dibandingkan dengan desain A-B-A. Oleh karena itu validitas internal lebih meningkat sehingga hasil penelitian yang menunjukkan hubungan fungsional antara variabel terikat dan bebas lebih meyakinkan. Dengan 
membandingkan dua kondisi awal sebelum dan sesudah perlakuan adanya pengaruh perlakuan lebih dapat diyakinkan.

Pada desain A-B-A-B ini langkah pertama adalah mengumpulkan data subjek pada kondisi kondisi awal pertama (A1). Setelah data menjadi stabil pada kondisi kondisi awal, maka perlakuan (A1) diberikan. Pengumpulan data pada kondisi perlakuan dilaksanakan secara kontinyu sampai data mencapai trend dan level yang jelas. Setelah itu masing-masing kondisi yaitu kondisi awal (A1) dan perlakuan (B1) diulang kembali pada periode yang sama.

d. Desain B-A-B

Kadang-kadang ada waktu ketika perilaku individu adalah parah atau mengganggu (misalnya perkelaian di dalam kelas dan di luar kelas), peneliti tidak dapat menunggu kondisi awal yang ditetapkan. Dalam kasus ini, desain B-A-B mungkin digunakan. Dalam desain ini melibatkan sebuah perlakuan yang diikuti sebuah kondisi awal diikuti perlakuan lagi. Gambar 2.5 memperlihatkan desain B-A-B. 


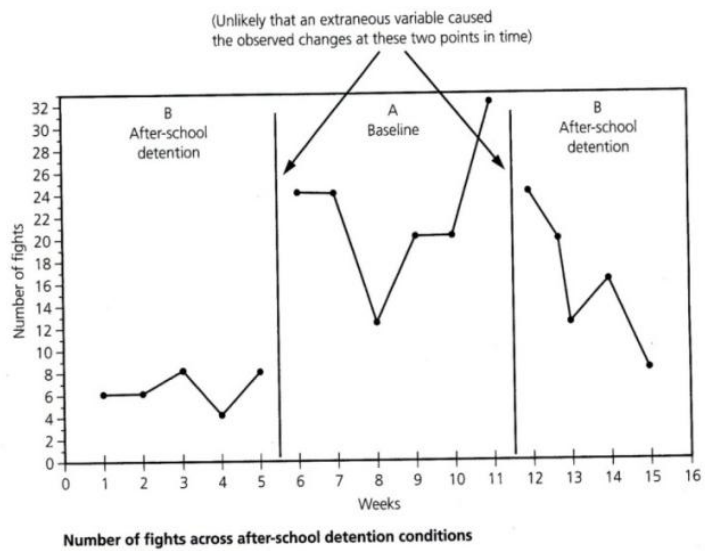

Gambar 2.5 Desain B-A-B

e. Desain A-B-C-B

Desain A-B-C-B merupakan modifikasi dari desain A-B-A, di mana $C$ mengacu pada variasi dari perlakuan kondisi "B". Dalam dua kondisi pertama, data kondisi awal dan perlakuan dikumpulkan. Selama kondisi "C" perlakuan diubah untuk mengendalikan perhatian ekstra yang telah diterima selama kondisi "B". Misalnya, dalam contoh kita sebelumnya, orang mungkin berpendapat bahwa itu bukan pujian yang bertanggung jawab atas peningkatan responsivitas, melainkan perhatian ekstra yang diterima . Kondisi " $C$ " merupakan pujian yang diberikan tidak peduli bagaimana menanggapinya (apakah dia menanggapi atau tidak). Seperti ditunjukkan pada Gambar 2.6, suatu kesimpulan dapat diperoleh yang menyatakan bahwa pujian yang selektif sangat penting untuk 
meningkatkan daya tanggap dibandingkan dengan keseluruhan pujian.

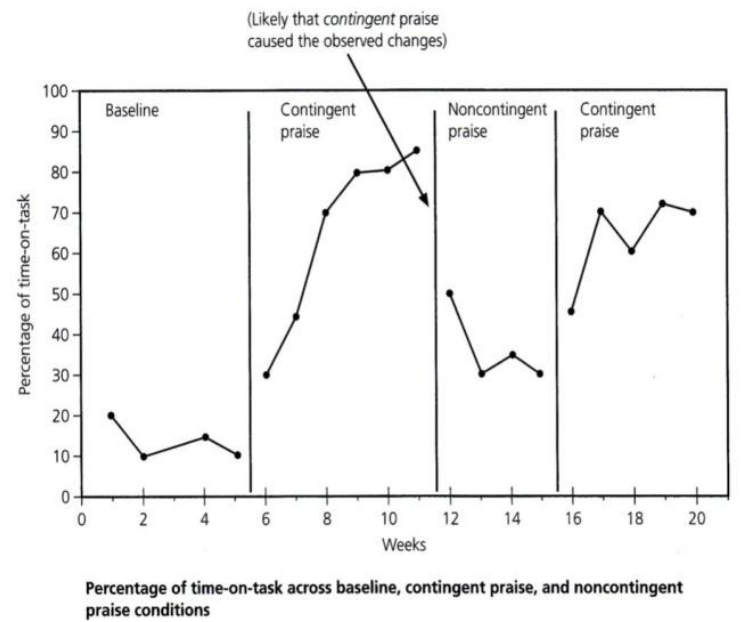

Gambar 2.6 Desain A-B-C-B

f. Desain Multiple Kondisi Awal

Sebuah alternatif untuk desain A-B-A-B adalah multiple-baseline design. Multiple-baseline design digunakan ketika tidak mungkin untuk menarik kembali perlakuan dan kembali pada kondisi awal. Ketika mulitiple-baseline design digunakan, peneliti melakukan pengumpulkan data tentang satu perilaku pada satu setting; mereka mengumpulkan beberapa perilaku untuk satu setting, mendapatkan kondisi awal untuk masing-masing perilaku selama periode yang sama.

Bila menggunakan multiple-baseline design, peneliti secara sistematis menerapkan perlakuan di 
waktu yang berbeda untuk setiap perilaku sampai semua menjalani perlakuan. Jika perubahan perilaku dalam setiap kasus hanya terjadi setelah perlakuan diterapkan, maka perlakuan dinilai yang menyebabkan perubahan tersebut. Penting bahwa perilaku diperlakukan, bagaimanapun, tetap independen satu sama lain. Jika perilaku kedua, sebagai contoh, diakibatkan oleh pendahuluan pada perlakuan pada perilaku pertama, maka efektivitas dari perlakuan tidak dapat ditentukan. Sebuah diagram dari multiplebaseline design yang melibatkan 3 perilaku sekaligus ditunjukkan pada Gambar 2.7 di bawah ini.

Behavior $1 \quad O O O O X O X O X O X O X O X O X O X O X O$ Behavior $2 O O O O O O O X O X O X O X O X O X O X O$ Behavior $3 O O O O O O O O O O O X O X O X O X O X O$

Gambar 2.7 Time-Series Design 

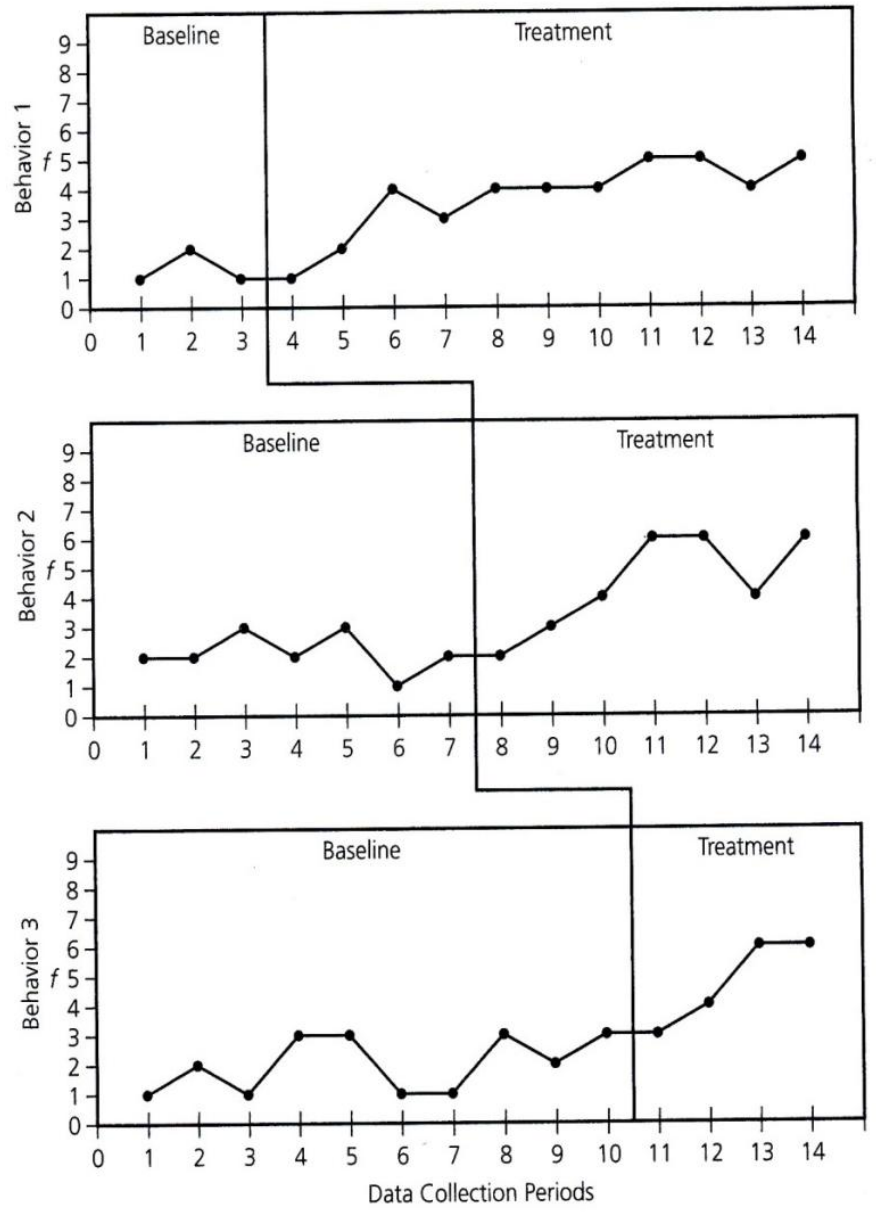

Gambar 2.8 Multiple-Baseline Design

Dalam desain ini, perlakuan diterapkan pertama untuk mengubah perilaku 1 , selanjutnya perilaku 2 , dan perilaku 3. Sebagai contoh, peneliti ingin meneliti pengaruh "time-out" (membebaskan siswa dari aktivitas kelas selama waktu tertentu) terhadap penurunan perilaku yang tidak diinginkan. Perilaku 
tersebut adalah a) berbicara sendiri, b) merobek lembar kerja, c) mengolok-olok siswa lain. Peneliti mulai menerapkan perlakuan "time-out" pertama untuk perilaku 1, selanjutnya perilaku 2 dan perilaku 3. Semakin banyak perilaku yang dapat dikurangi, semakin efektif perlakuan yang telah dilakukan. Berapa kali peneliti harus melakukan perlakuan adalah masalah penilaian dan bergantung pada yang terlibat, setting, dan perilaku yang diinginkan untuk dikurangi. Multiple-baseline design kadang digunakan untuk mengumpulkan data pada beberapa dengan mengamati satu perilaku, atau mengukur perilaku satu dalam dua atau lebih setting yang berbeda. Sebuah ilustrasi tentang pengaruh perlakuan dalam penelitian hipotesis menggunakan multiple-baseline design ditunjukkan pada Gambar 2.8. Perhatikan bahwa setiap perilaku yang terlibat berubah hanya ketika perlakuan diterapkan. Gambar 2.9 mengilustrasikan jika desain ini diterapkan pada setting yang berbeda. 


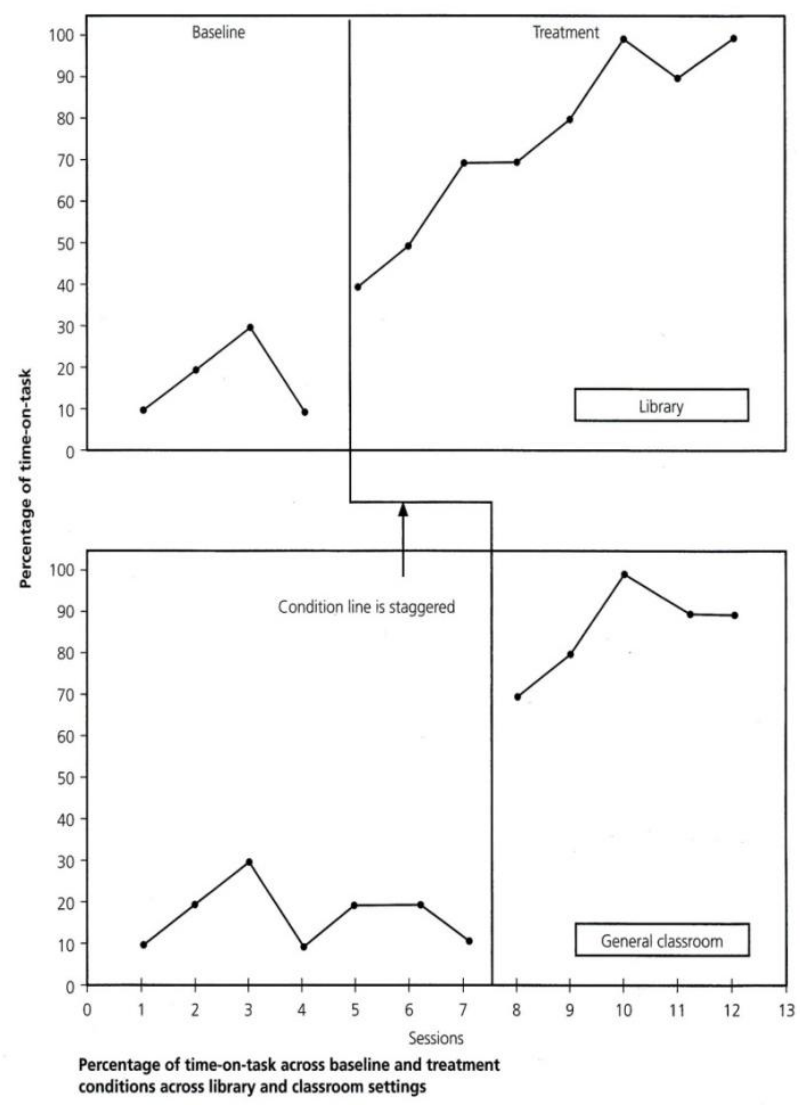

Gambar 2.9 Multiple-Baseline Design pada Setting Berbeda

3. Ancaman Validitas Internal Penelitian Tunggal

Ancaman validitas internal karena hal-hal berikut:
a. Waktu yang lama
b. Jumlah variabel yang berubah dari waktu ke waktu
c. Derajat dan kecepatan perubahan
d. Kembali ke level kondisi awal
e. Perilaku yang independen 


\section{Penelitian Survei (Survey Research)}

1. Karakteristik Survei

Survei atau dalam bahasa Inggris "survey". Survei adalah bertanya pada seseorang dan lalu jawabannya direkam. Survei adalah satu bentuk teknik penelitian di mana informasi dikumpulkan dari sejumlah sampel berupa orang, melalui pertanyaan-pertanyaan; satu cara mengumpulkan data melalui komunikasi dengan individuindividu dalam suatu sampel. Survei adalah metode pengumpulan data melalui instrumen yang bisa merekam tangapan-tanggapan responden dalam sebuah sampel penelitian. Walau umumnya orang bisa saling mempertukarkan istilah "survei" dengan "daftar pertanyaan", namun istilah survei digunakan sebagai kategori umum penelitian yang menggunakan kuesioner dan wawancara sebagai metodenya. Jadi, survei merupakan satu metode penelitian yang teknik pengambilan datanya dilakukan melalui pertanyaan tertulis atau lisan.

Di bawah ini disajikan beberapa karakteristik penelitian yang bentuknya survei:

1) Melibatkan sampel yang mampu mewakili populasi.

Teknik pengambilan sampelnya harus acak. 
2) Informasi yang dikumpulkan berasal langsung dari responden. Responden dapat menyatakan langsung pandangannya berdasarkan pertanyaan tertulis yang diberikan kepadanya (kuesioner), atau juga berdasarkan pertanyaan lisan (wawancara).

3) Sampel harus representatif (mewakili populasi), maka ukuran sampelnya banyak (sebanding dengan populasi), dibandingkan dengan metode lainnya.

4) Penarikan data dilakukan dalam tatanan yang natural, apa adanya, sesuai dengan kondisi sebenarnya.

Tujuan utama dari survei adalah untuk mendeskripsikan karakteristik dari suatu populasi. Intinya, apa yang ingin disimpulkan oleh peneliti adalah bagaimana respon mendistribusikan satu atau lebih variabel, seperti: usia, etnis/ suku, agama, dan sikap terhadap sekolah. Jadi, sampel yang dikumpulkan dari responden melalui survei dan pendeskripsian data dilakukan secara hati-hati dan populasi ditarik dari apa yang ditemukan pada sampel tersebut. Misalnya: peneliti tertarik untuk menguraikan bagaimana karakteristik (umur, jenis kelamin, etnis, dan politik) dari guru Sekolah Dasar yang ada dalam suatu kelompok, maka peneliti akan memilih guru-guru dalam kota tersebut sebagai sampel untuk disurvei.

2. Macam-macam Penelitian Survei 
Terdapat 2 (dua) tipe penelitian survei, yaitu:

a. Cross-sectional survey; di mana informasi dikumpulkan dari sampel yang diambil dari populasi yang telah ditetapkan. Bilamana seluruh populasi disurvei, maka hal ini disebut sensus.

b. Longitudinal survey; di mana informasi dikumpulkan pada titik waktu yang berbeda dari suatu waktu untuk mempelajari perubahan populasi. Tiga model survei longitudinal yang digunakan antara lain: trend studies, cohort studies, dan panel studies. Adapun penjelasan untuk masing-masing tipe sebagai berikut:

1) Trend studies; sampel yang berbeda dari populasi yang sama disurvei pada titik waktu yang berbeda.

2) Cohort studies; populasi yang khusus diikutkan selama periode waktu. Kalau sampel pada trend studies diambil dari populasi yang anggotanya berubah setiap waktu, maka sampel pada cohort studies diambil dari populasi yang anggotanya tidak berubah selama survei berlangsung.

3) Panel studies; sampel tidak berubah selama survei berlangsung. Peneliti mempelajari individu-individu yang sama, mencatat karakter atau sifat dan mencari penyebab adanya perubahan. 
3. Bentuk Penelitian Survei

a. Survei Dengan Cara Memberikan Daftar Pertanyaan

Kata kunci survei adalah "bertanya", artinya kalau mengadakan penelitian di mana datanya diperoleh dari hasil pertanyaan yang ajukan, maka penelitian tersebut sudah bisa dinamakan survei.

b. Survei melalui wawancara

Wawancara adalah teknik pengambilan data melalui pertanyaan yang diajukan secara lisan kepada responden. Umumnya teknik pengambilan data dengan cara ini dilakukan jika peneliti bermaksud melakukan analisis kualitatif atas penelitiannya. Wawancara bisa dilakukan secara tatap muka di antara peneliti dengan responden dan bisa juga melalui telepon. Di bawah ini digambarkan sebuah model yang menggambarkan berbagai variabel yang mempengaruhi proses wawancara.

Kekuatan wawancara, terdiri atas :

a. Flexibility. Pewancara dapat secara luwes mengajukan pertanyaan sesuai dengan situasi yang dihadapi pada saat itu.

b. Response rate. Maknanya, wawancara cenderung ditanggapi secara lebih baik dibandingkan dengan kuesioner yang diposkan. 
c. Non-verbal behavior. Pewawancara dapat mengobservasi perilaku nonverbal.

d. Control over environment. Pewawancara dapat mengatur lingkungan di mana wawancara dilakukan.

e. Question order. Pertanyaan dapat diajukan secara berurutan sehingga responden dapat memahami maksud penelitian secara lebih baik.

f. Spontaneity. Pewawancara dapat merekam jawaban-jawaban yang spontan.

g. Respondent alone can answer. Jawaban tidak dibuat oleh orang lain tetapi benar oleh responden yang telah kita tetapkan.

h. Completeness. Pewawancara dapat memperoleh jawaban atas seluruh pertanyaan yang diajukan.

i. Time of interview. Pewawancara dapat menyusun jadwal wawancara yang relatif pasti. Kapan, di mana, sehingga data yang diperoleh tidak keluar dari rancangan penelitian.

j. Greater complexity of questionnaire. Kuesioner umumnya berisikan pertanyaan yang mudah dijawab oleh responden.

Sedangkan kelemahan wawancara adalah :

a. Cost. Biaya supervisi lapangan, biaya latihan pewawancara, biaya perjalanan serta pemondokan, imbalan bagi responden, dan lain. 
b. Time. Waktu wawancara tidak dapat dilakukan kapan saja. Kadang responden hanya punya waktu sedikit, sehingga untuk menjawab seluruh pertanyaan diperlukan beberapa kali wawancara.

c. Interview bias. Walau telah dilakukan tatap muka, namun kesalahan bertanya dan juga kesalahan menafsirkan jawaban, masih bisa terjadi.

d. Inconvenience. Karena kesibukan atau alasan lainnya, tidak sedikit responden mau diwawancarai.

e. Less anonymity. Dibanding melalui kuesioner, melalui wawancara responden sulit menyembunyikan identitas dirinya.

f. Less standardized question wording. Pertanyaan sering kali kurang baku.

\section{Penelitian Korelasi (Correlational Research)}

1. Karakteristik Penelitian Korelasi

Penelitian korelasi merupakan salah satu bagian penelitian ex-post facto karena pada umumnya peneliti tidak memanipulasi keadaan variabel yang ada dan langsung mencari adanya suatu hubungan dan tingkat hubungan variabel yang dinyatakan dalam koefisien korelasi. Penelitian korelasi merupakan suatu penelitian yang melibatkan kegiatan pengumpulan data untuk menentukan, adakah hubungan dan tingkat hubungan 
antara 2 (dua) variabel atau lebih. Terdapatnya suatu hubungan dan tingkat variabel ini penting, karena dengan mengetahui tingkat hubungan yang ada, peneliti akan dapat mengembangkannya sesuai dengan tujuan penelitian.

Penelitian korelasi mempunyai 3 karakteristik penting bagi para peneliti yang akan menggunakannya (Sukardi, 2008). Tiga karakteristik tersebut, di antaranya yaitu:

a. Penelitian korelasi tepat bila variabel kompleks dan peneliti tidak memungkinkan untuk melakukan manipulasi dan kontrol variabel seperti pada penelitian eksperimen.

b. Memungkinkan variabel dilakukan pengukuran secara intensif dalam setting atau lingkungan nyata.

c. Memungkinkan peneliti memperoleh derajat asosiasi yang signifikan.

Penelitian korelasi memiliki tujuan untuk menentukan ada atau tidaknya hubungan antara 2 (dua) variabel atau lebih, ke arah manakah hubungan tersebut positif atau negatif, dan seberapa jauh hubungan yang ada antara 2 (dua) variabel atau lebih yang dapat diukur. Misalnya: hubungan antara kecerdasan dengan kreativitas, tinggi badan dengan umur, motivasi dengan prestasi, nilai bahasa Inggris dengan nilai statistika, dan 
sebagainya. Tujuan dari penyelidikan korelasi adalah untuk mengungkapkan atau menetapkan suatu hubungan atau menggunakan hubungan-hubungan dalam membuat prediksi atau perkiraan.

Dalam bidang pendidikan, studi korelasi umumnya digunakan guna melakukan penelitian terhadap sejumlah variabel yang diperkirakan memiliki peranan yang signifikan dalam mencapai proses pembelajaran. Sebagai contoh, mengenai hasil belajar dengan motivasi, intensitas kehadiran mengikuti kuliah, strategi belajar, dan Indeks Prestasi Semester (IPS).

Para peneliti akan tepat menggunakan penelitian korelasi dengan alasan sebagai berikut:

a. Adanya kebutuhan akan informasi bahwa ada hubungan antar variabel yang mana koefisien korelasi dapat mencapainya.

b. Penelitian korelasi harus memperhitungkan manfaatnya jika variabel yang muncul tersebut kompleks, dan peneliti tidak mungkin bisa melakukan kontrol dan memanipulasi variabelvariabel itu.

c. Apabila dalam penelitian memungkinkan untuk melakukan pengukuran beberapa variabel dan hubungan yang ada dalam setting yang realistis. 
d. Penelitian korelasi tepat dilakukan, bila salah satu tujuan penelitian adalah untuk mencapai formula prediksi, yaitu keadaan yang menunjukkan terdapatnya asumsi hubungan antar variabel.

2. Macam-Macam Studi Korelasi

a. Studi Hubungan

Studi hubungan biasanya dilakukan dalam usaha mendapatkan pemahaman faktor atau variabel yang berhubungan dengan variabel yang kompleks, misalnya seperti hasil belajar, konsep diri, dan motivasi belajar. Variabel yang diketahui tidak mempunyai hubungan dapat dieliminasi dari perhatian atau dipertimbangan. Identifikasi variabel yang berhubungan dapat membantu beberapa tujuan utama. Pertama, studi hubungan dapat memberikan arah untuk melanjutkan studi kausalkomparatif ataupun eksperimental.

Dalam studi kausal-komparatif dan eksperimental, peneliti juga berkonsentrasi terhadap pengontrolan variabel selain variabel bebas, yang mungkin saja berhubungan dengan variabel terikat dan menghilangkan pengaruhnya agar tidak bercampur dengan pengaruh variabel bebas. Studi hubungan dapat membantu peneliti mengidentifkasi variabel-variabel seperti itu, yang 
berguna untuk mengontrol, dan selanjutnya menyelidiki pengaruh variabel bebas yang sesungguhnya.

b. Studi Prediksi

Bila variabel mempunyai hubungan yang signifikan, skor pada satu variabel dapat dipakai untuk memprediksikan skor pada variabel yang lainnya. Sebagai contoh, Peringkat SMA, dapat dipakai untuk memprediksikan peringkat di perguruan tinggi. Variabel yang mendasar sebagai acuan pembuatan kriteria.

Studi prediksi sering dilakukan guna memudahkan dalam pengambilan kesimpulan mengenai individu atau membantu dalam pemilihan individu. Studi prediksi juga dijalankan guna menguji hipotesis teoritis tentang variabel yang dipercaya menjadi prediktor pada suatu kriteria, dan guna menentukan validitas prediktif dari instrumen pengukuran individual, misalnya IPS semester pertama tinggi akan dapat memprediksikan IPS selanjutnya mahasiswa juga akan tinggi.

Bila beberapa variabel prediktor masingmasing mempunyai hubungan dengan suatu variabel kriteria, prediksi yang didasarkan pada kombinasi dari beberapa variabel akan lebih akurat 
daripada 2 (dua) variabel. Sebagai contoh, prediksi hasil belajar mahasiswa ditentukan oleh kehadiran, partisipasi, nilai tugas, nilai ujian tengah semester, dan nilai akhir semester.

c. Korelasi dan Kausalitas

Penelitian korelasi merupakan suatu studi bertujuan untuk mengungkapkan hubungan antar variabel melalui pengujian statistika korelasi ( $r$ ). Kuadrat dari koefisien korelasi akan menghasilkan varians yang dijelaskan ( $r$-square). Suatu hubungan korelasi antara 2 (dua) variabel kadang kala merupakan hasil dari sumber lain, jadi peneliti berhati-hati dalam menjelaskan sebab dan akibat. Bila suatu hubungan yang kuat ditemukan antara 2 (dua) variabel, kausalitas dapat diuji melalui penerapan pendekatan eksperimental.

Berbagai rancangan penelitian korelasi umumnya didasarkan pada asumsi bahwa realitas lebih baik dideskripsikan sebagai suatu jaringan timbal balik dan penginteraksian daripada hubungan kausal. Sesuatu mempengaruhi dan dipengaruhi oleh sesuatu yang lain. Jaringan hubungan ini tidak linier, seperti dalam penelitian eksperimental. Dengan demikian, dinamika suatu sistem lebih penting daripada hubungan kausalitas. Sebagai 
suatu kaidah, rancangan korelasional seperti analisis jalur (path analysis) dan rancangan panel lintasakhir (cross-lagged panel designs) membolehkan pernyataan-pernyataan kausal.

3. Rancangan Penelitian Korelasi

Penelitian korelasi mempunyai bermacam jenis rancangan di antaranya, yaitu (1) korelasi bivariat, (2) regresi dan prediksi, (3) regresi jamak, (4) analisis faktor, dan (5) rancangan korelasi yang digunakan untuk membuat kesimpulan kausal. Rancangan penelitian sebagai berikut:

a. Korelasi Bivariat

Rancangan penelitian korelasi bivariat merupakan rancangan penelitian yang memiliki tujuan untuk mendeskripsikan hubungan antara 2 (dua) variabel. Hubungan antara 2 (dua) variabel tersebut dapat diukur. Hubungan tersebut mempunyai tingkatan dan arah.

Tingkat hubungan menunjukkan bagaimana atau seberapa kuat hubungan tersebut, umumnya diungkapkan antara -1 dan +1 , artinya tingkatan hubungan itu dinamakan koefisien korelasi. Korelasi zero (0) mengindikasikan tidak adanya hubungan antar variabel. Arah hubungan diindikasikan dengan semakin tinggi skor pada suatu variabel, semakin 
tinggi pula skor pada variabel lain dan begitu pula sebaliknya. Hubungan antara prestasi dan motivasi belajar merupakan contoh korelasi positif. Sedangkan, hubungan antara kesehatan dan stress merupakan contoh korelasi negatif.

b. Regresi dan Prediksi

Bila terdapat korelasi antara 2 (dua) variabel, dan peneliti mengetahui skor pada salah satu variabel, peneliti dapat memprediksikan skor pada variabel kedua. Regresi merujuk pada seberapa baik peneliti bisa membuat prediksi semacam ini. Sebagaimana pendekatan koefisien korelasi baik yang bernilai -1 maupun +1 , prediksi peneliti dapat lebih baik. Sebagai contoh, terdapat hubungan antara kesehatan dan stress. Jika peneliti mengetahui skor stress seseorang, maka peneliti mampu memprediksikan skor kesehatan seseorang tersebut di masa yang akan datang.

C. Regresi Jamak (Multiple Regression)

Regresi jamak adalah perluasan regresi dan prediksi sederhana dengan menambahkan beberapa variabel. Kombinasi beberapa variabel ini dapat memberikan lebih banyak kekuatan kepada peneliti untuk membuat prediksi yang lebih akurat. Apa yang peneliti prediksikan disebut variabel kriteria 
(criterion variabel), sedangkan variabel-variabel yang telah diketahui, disebut variabel prediktor (predictor variables).

Jika peneliti tidak hanya mengetahui skor stress, akan tetapi juga mengetahui skor perilaku kesehatan atau seberapa baik seseorang memperhatikan dirinya sendiri, dan bagaimana kesehatan seseorang selama ini secara umum sehat atau sakit, maka peneliti akan lebih dapat memprediksikan secara lebih tepat status kesehatan seseorang. Dengan demikian, terdapat 3 (tiga) variabel prediktor stress, perilaku kesehatan, dan status kesehatan sebelumnya, dan satu variabel kriteria, yaitu kesehatan di masa akan datang.

d. Analisis Faktor

Prosedur statistika yang satu ini mengidentifikasi pola variabel yang ada. Sejumlah besar variabel dikorelasikan dan terdapatnya antar korelasi yang tinggi mengindikasikan suatu faktor penting yang umum.

Sebagai contoh, peneliti dapat mengukur sejumlah besar aspek kesehatan fisik, mental, emosi, dan spiritual. Setiap pertanyaan akan memberikan kepada peneliti suatu skor. Korelasi yang tinggi baik positif maupun negatif antara 
beberapa skor ini akan mengindikasikan faktor penting yang bersifat umum. Banyak pertanyaan berbeda yang dapat diberikan, yang kemungkinan dapat mengukur faktor kesehatan emosional. Dalam kasus ini akan terdapat korelasi yang tinggi antara pertanyaan tentang marah, depresi, cemas, dan seterusnya. Atau di lain pihak, bila masing-masing pertanyaan merupakan faktor terpisah, akan terdapat korelasi yang kecil antara pertanyaan yang berhubungan dengan marah, depresi, cemas, dan seterusnya.

4. Kesalahan dalam Penelitian Korelasi

Kesalahan-kesalahan yang sering dilakukan peneliti dalam penelitian korelasi sebagai berikut:

a. Peneliti memilih statistika yang tidak tepat;

b. Peneliti berasumsi bahwa korelasi merupakan bukti sebab akibat;

c. Peneliti bertumpu pada pendekatan short-gun approach;

d. Peneliti tidak melakukan studi validitas silang;

e. Peneliti menggunakan analisis bivariat ketika multivariat yang lebih tepat;

f. Peneliti salah tafsir terhadap signifikansi praktis atau statistik dalam suatu studi; 
g. Peneliti menggunakan analisis jalur tanpa peninjauan asumsi-asumsi (teori);

h. Peneliti gagal menentukan suatu variabel kausal penting dalam perencanaan suatu analisis jalur.

5. Kelebihan dan Kelemahan Penelitian Korelasi

Penelitian korelasi mempunyai kelebihan antara lain yaitu: kemampuannya untuk menyelidiki hubungan antara beberapa variabel secara bersama-sama (simultan) dan penelitian korelasi mampu memberikan informasi tentang derajat kekuatan hubungan antara variabel-variabel yang diteliti. Selanjutnya, penelitian ini bermanfaat untuk mengatasi masalah yang berkaitan dengan bidang pendidikan, sosial, ekonomi. Penelitian korelasi memungkinkan untuk menyelidiki beberapa variabel yang diselidiki secara intensif dan penelitian ini bisa melakukan analisis prediksi tanpa membutuhkan sampel yang besar.

Sedangkan, untuk kelemahan penelitian korelasi di antaranya: hasilnya hanya mengidentifikasi sesuatu sejalan dengan sesuatu, tidak harus menunjukkan saling hubungan yang bersifat kausal; bila dibandingkan dengan penelitian eksperimental, penelitian korelasional ini kurang tertib dan ketat, karena kurang melakukan pengontrolan terhadap variabel-variabel bebasnya; pola saling berhubungan itu sering tidak menentu dan kabur 
atau kurang jelas; sering merangsang penggunanya sebagai semacam short-gun approach, yaitu memasukkan berbagai data tanpa melakukan pemilihan dan menggunakan setiap interpretasi yang berguna atau bermakna.

\section{E. Penelitian Kausal Komparatif}

1. Karakteristik Penelitian Kausal Komparatif

Penelitian kausal komparatif adalah penelitian yang dilakukan untuk membandingkan suatu variabel (objek penelitian), antara yang berbeda atau waktu yang berbeda dan menemukan hubungan sebab-akibatnya. Menurut Kerlinger, penelitian kausal komparatif (causal-comparative research) disebut juga penelitian ex-post facto adalah penyelidikan empiris yang sistematis di mana peneliti tidak mengendalikan variabel bebas secara langsung karena keberadaan dari variabel tersebut telah terjadi atau karena variabel tersebut pada dasarnya tidak dapat dimanipulasi (Emzir, 2011).

Gay mengemukakan bahwa studi kausal komparatif atau ex-post facto adalah penelitian yang berusaha menentukan penyebab atau alasan, untuk keberadaan perbedaan dalam perilaku atau status dalam kelompok individu. Dengan kata lain, penelitian kausal komparatif adalah penelitian yang diarahkan untuk menyelidiki hubungan 
sebab-akibat berdasarkan pengamatan terhadap akibat yang terjadi dan mencari faktor yang menjadi penyebab melalui data yang dikumpulkan. Dalam penelitian ini pendekatan dasarnya adalah memulai dengan adanya perbedaan 2 (dua) kelompok dan kemudian mencari faktor yang mungkin menjadi penyebab atau akibat dari perbedaan tersebut.

Berdasarkan pengertian di atas, sebagian ahli menyebutkan ex-post facto (bahasa latin 'setelah fakta') karena peneliti tidak memulai prosesnya dari awal, melainkan langsung melihat hasilnya. Dari hasil yang diperoleh tersebut peneliti mencoba mencari sebab-sebab terjadinya peristiwa itu. Adapun tujuan penelitian ini adalah untuk menyelidiki kemungkinan hubungan sebab-akibat berdasarkan atas pengamatan terhadap akibat yang ada, dan mencari kembali fakta yang mungkin menjadi penyebab melalui data tertentu.

Penelitian kausal komparatif dapat dilihat seperti berikut: 1) Variabel penyebab tidak dimanupulasi karena telah terjadi dan 2) Variabel terikat variabel bebas. Ritz mengindentifikasikan beberapa keunggulan dan kelemahan penelitian kausal komparatif. Keunggulan Penelitian kausal komparatif

a. Metode kausal komparatif adalah suatu penelitian yang baik untuk berbagai keadaan kalau metode yang lebih kuat, yaitu metode eksperimental, tidak dapat digunakan ketika: 
1) Apabila tidak memungkinkan untuk memilih, mengontrol dan memanipulasikan faktor-faktor yang perlu untuk menyelidiki hubungan sebab-akibat secara langsung.

2) Apabila pengontrolan terhadap semua variabel kecuali variabel bebas sangat tidak realistis dan dibuat-buat, yang mencegah interaksi normal dengan lain-lain variabel yang berpengaruh.

3) Apabila kontrol di laboratorium untuk berbagai tujuan penelitian adalah tidak praktis, terlalu mahal, atau dipandang dari segi etika diragukan/ dipertanyakan.

b. Studi kausal-komparatif menghasilkan informasi yang sangat berguna mengenai sifat-sifat gejala yang dipersoalkan: sejalan dengan apa, dalam kondisi apa, pada urutan dan pola yang bagaimana dan sebagainya.

c. Perbaikan-perbaikan dalam hal teknik, metode statistika, dan rancangan dengan kontrol parsial, pada akhir-akhir ini telah membuat studi kausal-komparatif itu lebih dapat dipertanggung jawabkan.

Kelemahan Penelitian Kausal Komparatif

a. Kelemahan utama setiap rancangan ex-post facto adalah tidak adanya kontrol terhadap variabel bebas. Dalam batas-batas pemilihan yang dapat dilakukan, peneliti harus mengambil fakta-fakta yang dijumpainya tanpa kesempatan untuk mengatur kondisi-kondisinya atau 
memanipulasi variabel-variabel yang mempengaruhi. Untuk dapat mencapai kesimpulan, peneliti harus mempertimbangkan segala alasan yang mungkin ada atau hipotesis-hipotesis yang mungkin diajukan yang mempengaruhi hasil-hasil yang dicapai.

b. Sulit untuk memperoleh kepastian bahwa faktor-faktor penyebab yang relevan telah benar-benar tercakup dalam kelompok faktor-faktor yang sedang diselidiki.

c. Kenyataan bahwa faktor penyebab bukanlah faktor tunggal, melainkan kombinasi dan interaksi antara berbagai faktor dalam kondisi tertentu untuk menghasilkan efek yang disaksikan, menyebabkan masalah menjadi sangat kompleks.

d. Suatu gejala mungkin tidak hanya merupakan akibat dari sebab-sebab ganda, tetapi dapat pula disebabkan oleh sesuatu sebab pada kejadian tertentu dan oleh lain sebab pada kejadian lain.

e. Apabila saling hubungan antara 2 (dua) variabel telah diketemukan, mungkin sulit untuk menentukan mana yang sebab dan mana yang akibat.

f. Kenyataan bahwa dua atau lebih faktor saling berhubungan tidaklah selalu memberi implikasi adanya hubungan sebab-akibat. Kenyataan itu mungkin hanyalah karena faktor-faktor tersebut berkaitan dengan faktor lain yang tidak diketahui atau tidak terobservasi. 
g. Menggolong-golongkan ke dalam kategori dikotomi (misalnya: golongan pandai dan golongan bodoh) untuk tujuan pembandingan, menimbulkan persoalan-persoalan, karena kategori-kategori seperti itu bersifat kabur, bervariasi dan tidak mantap. Seringkali penelitian yang demikian itu tidak menghasilkan penemuan yang berguna.

h. Studi komparatif dalam situasi alami tidak memungkinkan pemilihan secara terkontrol. Menempatkan kelompok yang telah ada yang mempunyai kesamaan dalam berbagai hal kecuali dalam hal dihadapkannya pada variabel bebas adalah sangat sulit.

\section{F. Penelitian Eksperimen}

1. Karaktersitik Penelitian Eksperimen

Penelitian eksperimen merupakan suatu penelitian yang menjawab pertanyaan "jika kita melakukan sesuatu pada kondisi yang dikontrol secara ketat maka apakah yang akan terjadi?". Untuk mengetahui apakah ada perubahan atau tidak pada suatu keadaan yang dikontrol secara ketat maka memerlukan perlakuan (treatment) pada kondisi tersebut dan hal inilah yang dilakukan pada penelitian eksperimen. Sehingga, penelitian eksperimen dapat dikatakan sebagai metode penelitian yang digunakan untuk mencari pengaruh perlakuan tertentu terhadap yang lain dalam kondisi yang terkendalikan (Sugiyono, 2013). 
Penelitian eksperimen adalah suatu penelitian yang di dalamnya ditemukan minimal satu variabel yang dimanipulasi untuk mempelajari hubungan sebab-akibat. Oleh karena itu, penelitian eksperimen erat kaitannya dalam menguji suatu hipotesis dalam rangka mencari pengaruh, hubungan, maupun perbedaan perubahan terhadap kelompok yang dikenakan perlakuan.

Beberapa karakteristik penelitian eksperimen, yaitu :

a. Variabel-variabel penelitian dan kondisi eksperimen diatur secara ketat, dengan menetapkan kontrol, memanipulasi langsung, maupun random (acak).

b. Adanya kelompok kontrol untuk dibandingkan dengan kelompok eksperimen.

c. Penelitian ini memusatkan diri pada pengontrolan variabel, untuk memaksimalkan variabel yang berkaitan dengan hipotesis penelitian, meminimalkan variabel pengganggu yang mungkin mempengaruhi hasil eksperimen. Di samping itu, penelitian ini meminimalkan kekeliruan, termasuk kekeliruan pengukuran. Untuk itu, sebaiknya pemilihan dan penentuan kelompok-kelompok dilakukan secara acak.

d. Validitas internal mutlak diperlukan pada rancangan penelitian eksperimen, untuk mengetahui apakah manipulasi eksperimen yang dilakukan pada saat studi ini benar-benar menimbulkan perbedaan. 
e. Validitas eksternalnya berkaitan dengan bagaimana kerepresentatifan penemuan penelitian dan berkaitan dengan menggeneralisasikan pada kondisi yang sama.

f. Semua variabel diusahakan konstan, kecuali variabel perlakuan yang secara sengaja dimanipulasi atau dibiarkan bervariasi.

Selain itu, dalam penelitian eksperimen ada 3 (tiga) unsur penting yang harus diperhatikan, yaitu kontrol, manipulasi, dan pengamatan. Variabel kontrol adalah inti dari metode eksperimental, karena variabel kontrol inilah yang akan menjadi standar dalam melihat adanya perubahan, maupun perbedaan yang terjadi akibat perlakuan yang diberikan. Sedangkan manipulasi adalah perlakuan yang sengaja dilakukan dalam penelitian eksperimen. Dalam penelitian ini, yang dimanipulasi adalah variabel independent dengan melibatkan kelompokkelompok perlakuan yang kondisinya berbeda. Setelah peneliti menerapkan perlakuan eksperimen, maka peneliti harus mengamati untuk menentukan apakah hipotesis perubahan telah terjadi.

2. Desain Penelitian Eksperimen

Menurut Sugiyono (2013), desain penelitian ekperimen yaitu pre-experimental design, true experimental design, dan quasy experimental design. 
a. Pre-experimental Design

Desain ini dikatakan sebagai pre-experimental design karena belum merupakan eksperimen sesungguhnya karena masih terdapat variabel luar yang ikut berpengaruh terhadap terbentuknya variabel dependen. Rancangan ini berguna untuk mendapatkan informasi awal terhadap pertanyaan yang ada dalam penelitian. Bentuk Pre-Experimental Designs ini ada beberapa macam antara lain :

1) One - Shoot Case Study

Pada desain ini terdapat suatu kelompok diberi perlakuan dan selanjutnya diobservasi hasilnya (perlakuan adalah sebagai variabel independen dan hasil adalah sebagai variabel dependen). Dalam eksperimen ini disajikan dengan beberapa jenis perlakuan lalu diukur hasilnya.

2) One - Group Pretest-Posttest Design

Pada desain ini terdapat pretest sebelum diberi perlakuan. Dengan demikian hasil perlakuan dapat diketahui lebih akurat, karena dapat membandingkan dengan keadaan sebelum diberi perlakuan.

3) Intact-Group Comparison

Pada desain ini terdapat satu kelompok yang digunakan untuk penelitian, tetapi dibagi dua yaitu: setengah kelompok untuk eksperimen (yang diberi 
perlakuan) dan setengah untuk kelompok kontrol (yang tidak diberi perlakuan, bisa diartikan perlakuan yang diberikan yang umumnya diberikan pada kelompok).

b. True Experimental Design

Dikatakan true-experimental (eksperimen yang sesungguhnya) karena pada desain ini peneliti dapat mengontrol semua variabel luar yang mempengaruhi jalannya eksperimen. Dengan demikian validitas internal menjadi tinggi. Ciri utama dari true-experimental adalah bahwa, sampel yang digunakan untuk eksperimen maupun sebagai kelompok kontrol diambil secara random (acak) dari populasi tertentu. Desain trueexperimental terbagi atas :

1) Posstest-Only Control Design

Pada desain ini terdapat dua kelompok yang masing-masing dipilih secara random (R). Kelompok pertama diberi perlakuan (X) dan kelompok lain tidak (bisa diartikan perlakuan yang diberikan yang umumnya diberikan pada kelompok). Kelompok yang diberi perlakuan disebut kelompok eksperimen dan kelompok yang tidak diberi perlakuan disebut kelompok kontrol. 
2) Pretest-Posttest Control Group Design.

Pada desain ini terdapat dua kelompok yang dipilih secara acak/random, kemudian diberi pretest untuk mengetahui keadaan awal dengan tujuan adakah perbedaan antara kelompok eksperimen dan kelompok kontrol.

3) The Solomon Four-Group Design.

Dalam desain ini, di mana salah satu dari 4 (empat) kelompok dipilih secara random. Dua kelompok diberi pratest dan dua kelompok tidak. Kemudian satu dari kelompok pratest dan satu dari kelompok non-pretest diberi perlakuan eksperimen, setelah itu keempat kelompok ini diberi posttest.

c. Quasi Experimental Design

Desain eksperimen ini merupakan pengembangan dari true experimental design yang sulit dilaksanakan. Desain ini mempunyai kelompok kontrol, tetapi tidak dapat berfungsi sepenuhnya untuk mengontrol variabelvariabel luar yang mempengaruhi pelaksanaan eksperimen. Walaupun demikian, desain ini lebih baik dari pre-experimental design. Quasi Experimental Design digunakan karena pada kenyataannya sulit medapatkan kelompok kontrol yang benar-benar mengontrol apa yang seharusnya dikontrol, desain eksperimen ini sangat cocok digunakan di bidang pendidikan. 
Desain eksperimen model ini di antaranya sebagai berikut:

1) Time-Series Design

Dalam desain ini kelompok yang digunakan untuk penelitian tidak dapat dipilih secara random. Sebelum diberi perlakuan, kelompok diberi pretest sampai empat kali dengan maksud untuk mengetahui kestabilan dan kejelasan keadaan kelompok sebelum diberi perlakuan. Bila hasil pretest selama empat kali ternyata nilainya berbeda-beda, berarti kelompok tersebut keadaannya labil, tidak menentu, dan tidak konsisten. Setelah kestabilan keadaan kelompok dapat diketahui dengan jelas, maka baru diberi perlakuan. Desain penelitian ini hanya menggunakan satu kelompok saja, sehingga tidak memerlukan kelompok kontrol.

2) Non-equivalent Control Group Design

Desain ini hampir sama dengan pretest-posttest control group design, hanya pada desain ini kelompok eksperimen maupun kelompok kontrol tidak dipilih secara random. Dalam desain ini, baik kelompok eksperimen maupun kontrol dibandingkan, walaupun dipilih dan ditempatkan tanpa melalui random. Dua kelompok yang ada diberi pretest, kemudian diberikan perlakuan, dan terakhir diberikan posttest. 
3) Conterbalanced Design

Pada desain ini, semua kelompok menerima semua perlakuan, hanya dalam urutan perlakuan yang berbeda-beda, dan dilakukan secara random.

4) Factorial Design

Pada desain Faktorial selalu melibatkan dua atau lebih variabel bebas (sekurang-kurangnya satu yang dimanipulasi). Desain faktorial secara mendasar menghasilkan ketelitian dari desain true-experimental dan membolehkan penyelidikan terhadap 2 (dua) atau lebih variabel. Tujuan dari desain ini adalah untuk menentukan apakah efek suatu variabel eksperimen dapat digeneralisasikan melalui semua tingkatan dari suatu variabel kontrol, selain itu juga dapat digunakan untuk menunjukkan hubungan yang tidak dapat dilakukan oleh desain eksperimental variabel tunggal.

\section{G. Evaluasi}

Carilah artikel (masing-masing 2 sesuai bidang studi Anda) dari internet (free-access) dari masing-masing jenis penelitian kuantitatif, lalu buatlah ke dalam tabel emphirical mapping! 


\section{DAFTAR PUSTAKA}

Emzir. 2011. Metodologi Penelitian Kualitatif Analisis Data. Jakarta. Rajawali Pers

Fraenkel, et al. 2011. How to Design and Evaluate Research in Education 8th Edition. New York: McGraw-Hill.

Sugiyono. 2013. Metode Penelitian Kuantitatif Kualitatif dan R\&D. Bandung: CV. Alfabeta. 


\section{BAB III \\ METODOLOGI PENELITIAN KUALITATIF}

\section{A. Paradigma Penelitian Kualitatif}

Penelitian kualitatif pada awal diperkenalkannya ke kalangan peneliti, mendapat tolakan yang luar biasa sekitar tahun 1990. Pada saat itu, banyak tudingan bahwa hasil penelitian kualitatif tidak valid dan data yang didapatkan tidak absah karena peneliti terlalu tif, alat ukur variabel tidak jelas, adanya pandangan tidaklah mungkin mengulangi suatu peristiwa kalau data yang didapatkan haruslah natural tanpa adanya perlakuan sama sekali. Namun perlahan para peneliti kualitatif dapat meyakinkan kalangan peneliti lain yang tidak sependapat sebelumnya bahwa prinsip-prinsip penelitian kualitatif tidak menyalahi kaidah ilimiah penelitian.

Keunggulan penelitian kualitatif menutupi kelemahan penelitian lain, utamanya penelitian kuantitatif. Penelitian kualitatif mampu memberikan deskripsi informasi secara lebih rinci dan jelas dari penelitian, hal ini berbeda dengan penelitian kuantitatif yang hanya bisa memberikan informasi terukur berupa angka-angka. Penelitian kualitatif bisa memberikan hal yang berbeda di kalangan peneliti, berupa perluasan teori (grounded theory). Penelitian kuantitatif tidak bisa memberikan hal tersebut, sehingga terkesan konvensional 
dan sulit menerima perubahan. Beberapa kelebihan dan kelemahan penelitian kualitatif maupun penelitian kuantitatif ini, hendaknya kita sikapi sebagai penelitian yang saling melengkapi, dan akan kita gunakan sesuai kebutuhan, bukan saling mempertentangkan mana yang lebih baik sehingga menjadikan penelitian tidak objektif sesuai fakta permasalahan.

Kita harus bijak mengambil sikap bukan hanya karena tidak bisa mendeskripsikan kalimat, sehingga mengalihkan fakta untuk beralih pada penelitian kuantitatif atau sebaliknya merasa tidak bisa menggunakan rumus-rumus statistik sehingga beralih pada penelitian kualitatif. Hal ini tidak selamanya benar dilakukan dalam melakukan penelitian. Berdasarkan pengalaman penulis, sikap-sikap seperti itu banyak ditemukan saat mengajar mahasiswa S1, konsekuensi logis yang muncul adalah kualitas tulisan mahasiswa kurang baik karena tidak punya prinsip penelitian. Seyogyanya suatu penelitian berangkat dari masalah yang akan dicarikan solusi, bukan berangkat dari "suka tidak suka" atau "mau tidak mau". Sudah sepatutnya bagi kalangan praktisi termasuk akademisi, belajar memperdalam kelimuan riset menjadi tuntuan dalam melakukan suatu penelitian di era sekarang ini.

Adanya peneliti yang memandang bahwa penelitian yang melibatkan deskriptif kalimat selalu merupakan penelitian kualitatif, sementara penelitian yang melibatkan perhitungan angka-angka menggunakan rumus merupakan penelitian 
kuantitatif. Pandangan ini tidak selamanya benar, penelitian kuantitatif tidak mungkin hanya melibatkan perhitungan rumus, tanpa adanya deskripsi penafsiran data. Penelitian kualitatif juga tidak ada salahnya terdapat analisis data yang melibatkan rumus. Arikunto (2010), pandangan seperti itu dikarenakan para peneliti belum menguasai teori dan ciri-ciri penelitian kualitatif dan kuantitatif secara mendalam. Akibatnya, banyak penelitian yang disebutnya sebagai penelitian kualititaf tapi sebetulnya dapat dikatakan hanya deskripai saja. Mungkin ada baiknya, kita harus membedakan pengertian data kualitatif dan kuantitatif terlebih dahulu. Data kualitatif adalah data yang diwujudkan dalam kata keadaan atau kata sifat, misal "Sangat Baik", "Baik", dst. Sementara data kuantitatif adalah data yang berkenaan dengan angka-angka dan analisisnya menggunakan rumus statistik, misal rata-rata hasil belajar siswa 80, tingkat berpikir kreatif siswa pada kategori poin 4, poin 3, poin 2, atau poin 1.

Jadi dapat disintesiskan, baik penelitian kualitatif maupun kuantitatif sangat mungkin memiliki data kualitatif dan kuantitatif. Hanya memang apabila sebagian besar data yang diperoleh kuantitatif, maka biasanya metode yang digunakan adalah penelitian kuantitatif. Sedangkan apabila sebagian data kualitatif, maka analisis datanya biasa menggunakan metode penelitian kualitatif meskipun beberapa analisis data melibatkan rumus statistik dalam perhitungan. Dalam hal ini, 
tugas peneliti adalah mengidentifikasi karakterisik data-data penelitian yang didapatkan sehingga dapat membedakan metode penelitian yang tepat untuk digunakan.

Menurut Sugiyono (2013), metode penelitian kuantitatif dikenal dengan metode tradisional karena cukup lama dikenal, metode ini disebut juga dengan metode positivistic karena berlandaskan pada filsafat positivisme. Ada juga sebutan untuk metode kuantitatif yakni metode discovery, karena dapat menemukan dan mengembangkan iptek baru. Hal ini dimungkinkan karena data penelitian metode kuantitatif berupa angka-angka dan analisisnya menggunakan statistik untuk menguji hipotesis penelitian. Sementara metode penelitian kualitatif dikenal sebagai metode baru (belum lama), disebut sebagai metode positivistik karena berlandaskan pada filsafat postpositivisme. Dikenal juga dengan metode artistik, karena proses penelitian bersifat seni (kurang terpola). Analisis data pada penelitian kualitatif bernuansa interpretasi peneliti secara mendalam terhadap data yang ditemukan di lapangan. Oleh karena itu, peneliti sebagai intrumen utama memiliki kedudukan yang sangat penting, sehingga tidak terjadi bias data. Penelitian kualitatif lebih menekankan pada makna, bukan pada genealisasi. Namun bukan berarti pada penelitian kualitatif tidak bisa menggeneralisasi (menyimpulkan secara lebih umum dari keadaan yang diamati). Apabila terjadi generalisasi, maka generalisasi ini disebut transferability dan 
apabila terjadi perluasan teori, maka perluasan ini seringkali disebut grounded theory.

Menurut Moleong (2009), banyak pandangan tentang pengertian penelitian kualitatif, namun ada benang merah kesamaan yang dapat diambil, bahwa penelitian kualitatif adalah penelitian yang bertujuan untuk memahami fenomena alamiah yang dialami seorang penelitian secara holistik. Fenomena yang diamati bisa perilaku, persepsi, motivasi, tindakan, dll. Analisis penelitian kualitatif berupa deskripsi dalam bentuk kata-kata atau kalimat dan berlandaskan berbagai metode ilmiah.

Simpulan uraian-uraian di atas mengenai penelitian kualitatif adalah penelitian yang dilakukan seseorang untuk menginterpretasikan fenomena alamiah secara mendalam terhadap data di lapangan. Fenomena tersebut bisa berupa suatu perilaku, persepsi, motivasi, tindakan, dll. Penelitian kualitatif bukan untuk menggeneralisasi suatu makna hasil interpretasi data.

\section{B. Karakteristik Penelitian Kualitatif}

Pada dasarnya penelitian kualitatif bertumpu pada landasan fenomenologi. Fenomenologi merujuk pada pengamalan tertentu dari suatu kejadian dan suatu studi perspektif pokok dari seorang. Landasan dasar fenomenologi ini, menjadi dasar perbedaan ciri-ciri penelitian kualitatif 
dengan penelitian lain (Moleong, 2009). Adapun cirri-ciri tersebut meliputi:

a. Latar alamiah (Naturalistik)

Latar alamiah membawa implikasi penelitian kualitatif dilakukan tanpa adanya eksperimen atau tindakan suatu situasi. Peneliti tidak diperkenankan untuk merubah sedikitpun situasi saat melakukan penelitian dan peneliti harus terjun langsung untuk mengetahui aktivitas kejadian sesungguhnya.

Misal mahasiswa A yang ingin melakukan penelitian aktivitas siswa dalam sekolah $B$, maka mahasiswa $A$ harus melakukan pengamatan atau observasi langung di sekolah B. Karena latar alamiah, maka mahasiswa peneliti kualitatif harus berhati-hati dalam melakukan penelitian, jangan sampai yang diamati merasa terganggu sehingga data aktivitas yang didapatkan menjadi berbeda dengan kondisi peneliti (mahasiswa A) sebelum datang untuk melakukan penelitian. Tentu dalam ranah sosial di sekolah, konteks seperti ini memang sulit untuk dilakukan. Karena umunya siswa sebagai pengamatan merasa terganggu dan menganggap peneliti merupakan orang luar. Alternatif yang bisa dilakukan adalah peneliti harus "cerdas" memilih sekolah yang biasa dijadikan penelitian. Namun apabila sekolah tempat sebagai tempat pengambilan data belum pernah dijadikan tempat penelitian, maka pengamatan 
aktivitas dalam konteks sebelumnya bisa dilakukan beberapa kali sehingga data pengamatan aktivitas jenuh (tidak berubah) sebelum dilakukan analisa data.

b. Peneliti sebagai intrumen utama

Dalam proses penelitian kualitatif, meski peneliti sudah melakukan berbagai persiapan. Terkadang pada saat berlangsungnya pengambilan dan analisa data, data yang didapatkan dapat berbeda sebagaimana diprediksi sebelumnya. Meskipun juga ada intrumen atau alat bantu tertentu yang bukan manusia, hal ini tidak akan membantu banyak apabila peneliti tidak bisa menganalisa dengan baik permasalahan yang terjadi. Oleh karena itu, mutlak hukumnya dalam penelitian kualitatif, peneliti sebagai intrumen utama. Peneliti dalam hal ini bisa melibatkan pihak lain untuk mengkroscek data yang ada sehingga data yang didapatkan benar-benar akurat dan objektif.

c. Metode kualitatif

Penelitian kualitatif sebagian besar memiliki data kualitatif, data kualitatif digali melalui metode kualitatif diantaranya pengamatan, wawancara, penelaahan dokumen.

d. Analisis data secara induktif

Analisis data penelitian kualitatif dilakukan secara indukti (dari hal-hal kecil atau sederhana). Ada 5 alasan menurut Moleong (2009), mengapa analisis secara induktif 
dilakukan yakni (1) proses induktif lebih dapat menemukan fakta-fakta objektif secara mendetail, (2) analisis induktif lebih dapat membuat hubungan peneliti dan responden menjadi lebih eksplisit, dapat dikenal, dan akuntabel, (3) analisis induktif menguraikan latar alamiah secara penuh dan dapat membuat keputusan-keputusan jika ada pengalihan latar selama proses penelitian, (4) analisis induktif lebih dapat menemukan pengaruh bersama yang dapat mempertajam hubungan-hubungan variable pengamatan, (5) analisis induktif dapat memperhitungkan nilai-nilai secara lebih eksplisit dalam proses penelitian.

e. Teori dari dasar (grounded theory)

Penelitian kualitatif menekankan pada penyusunan teori substantif yang berasal dari data-data di lapangan. Hal ini berhubungan dengan analisis induktif bahwa upaya yang dilakukan peneliti dalam mencari data bukan untuk membuktikan hipotesis penelitian, tapi lebih merupakan pembentukan abstraksi-abstraksi penelitian dari fakta-fakta selama proses penelitian, untuk kemudian dilakukan pengelompokan data yang saling berhubungan.

f. Data Deskriptif

Deskriptif dalam penelitian kualitatif bermakna data yang dikumpulkan berupa kata-kata, gambar, dan bukan angka-angka. Sehingga proposal atau laporan penelitian yang dihasilkan berisi gambaran-gambaran dari penelitian. 
Deskirpsi data bisa berasal dari transkrip wawancara, catatan lapangan, foto, tape recorder, video, dokumen pribadi, atau catatan lainnya.

g. Lebih mementingkan proses daripada hasil

Penelitian kualitatif yang mementingkan hubungan bagian-bagian yang sedang diteliti selama pengamatan fakta-fakta khusus selama proses penelitian, dan juga penelitian kualitatif tindak bertujuan untuk menguji hipotesis membawa konsekuensi logis penelitian kualitatif lebih mementingkan proses daripada hasil.

h. Adanya fokus penelitian

Penelitian kualitatif membutuhkan fokus penelitian yang akan diamati, di lapangan peneliti kualitatif akan melihat data secara luas. Jika hal ini tidak diambil sikap dengan memfokuskan penelitian melalui batasan pengamatan atau data pengamatan. Maka peneliti kualitatif akan kesulitan mengumpulkan, menyajikan, menganalisa data sampai pada membuat laporan penelitian. Oleh karena itu, peneliti kualitatif harus menetapkan fokus penelitian sebelum melakukan penelitian di lapangan.

i. Adanya kriteria khusus untuk absahnya data

Berbeda dengan penelitian kuantitatif yang untuk memeriksa keabsahan data menggunakan validitas, reliabilitas, dan objektivitas. Penelitian kualitatif menggunakan cara lain untuk memeriksa keabsahan data, 
salah satu diantaranya triangulasi data. (Lebih lanjut dijelaskan pada sub bab analisis data penelitian kualitatif berikutnya).

j. Desain bersifat sementara

Penelitian kualitatif memiliki desain yang bersifat sementara, artinya desain yang sudah direncanakan dapat saja diubah sesuai kondisi real dilapangan. Misal peneliti kualitatif sebelum penelitian merencanakan untuk mengetahui proses penalaran matematik siswa sekolah dasar dalam memecahkan masalah luas segitiga pada model pembelajaran discovery learning, namun peneliti masih belum mendapatkan data penalaran siswa yang ajeg dan utuh. Maka peneliti bisa melakukan pengamatan kembali pada pertemuan selanjutnya.

k. Hasil penelitian didiskusikan dan disepakati bersama.

Penelitian kualitatif menghendaki adanya kesepakatan atau diskusi interpretasi data antara peneliti dengan yang dijadikan sumber data untuk menjaga objektivitas dan originalitas data sehingga terhindar dari interpretasi tif peneliti yang seringkali terjadi dalam penelitian kualitatif.

Karakteristik-karakteristik penelitian kualitatif berimplikasi pada penelitian kualitatif tidak memiliki jenis penelitian tertentu karena penelitian kualitatif yang "baik" tidak hanya dilakukan secara deskriptif yang selama ini banyak 
dipandang oleh peneliti. Penelitian kualitatif harus memiliki semua karakteristik yang telah dijelaskan di atas.

\section{Rumusan Masalah dan Judul Penelitian Kualitatif}

Sebagaimana yang dijelaskan sebelumnya, penelitian kualitatif bertujuan untuk memaknai interpretasi data alamiah di lapangan. Oleh karena itu, pertanyaan penelitian atau rumusan masalah penelitian kualitatif juga bertujuan untuk memahami gejala kompleks secara mendalam. Menurut Sugiyono (2013), hal ini membawa dampak pada rumusan masalah penelitian kualitatif meliputi rumusan masalah deskriptif, komparatif, dan asosiatif untuk memahami interpretasi makna suatu data. Sementara, judul penelitian kualitatif harus spesifik dan mencerminkan permasalahan data yang akan diamati.

Berikut beberapa contoh rumusan masalah dan judul penelitian kualitatif pada bidang pendidikan tentang suatu pembelajaran.

Fokus Penelitian: Pembelajaran Kooperatif

Judul Penelitian: Penerapan pembelajaran kooperatif di kelas V Sekolah Dasar Tertentu di wilayah XXX

Rumusan Masalah:

a. Bagaimanakah aktivitas belajar siswa di kelas $\mathrm{V}$ sekolah dasar tertentu di wilayah XXX? (masalah deskriptif) 
b. Bagaimanakah pola interaksi siswa dengan siswa, siswa dengan guru, dan guru dengan siswa dalam pembelajaran kooperatif di kelas V sekolah dasar tertentu di wilayah XXX? (masalah asosiatif)

c. Apakah proses pembelajaran kooperatif di kelas $\mathrm{V}$ sekolah dasar tertentu berbeda dengan sekolah dasar lain di wilayah XXX?

\section{Analisis Penelitian Kualitatif}

Data penelitian kualitatif dikumpulkan dari berbagai macam dan menggunakan teknik pengumpulan data yang bermacam-macam pula (triangulasi). Perolehan data tersebut dilakukan berkali-kali sampai makna data jenuh (tidak berubah). Sebagai peneliti kualitatif, harus hati-hati memahami pengertian triangulasi yang terdiri dari kata tri=tiga dan angulasi $=$ sudut. Dari istilah tersebut bukan berarti hanya terdapat tiga cara pengumpulan data dalam penelitian kualitatif, misal pengumpulan data pendapat proses pembelajaran di suatu kelas dari informan sebagai sumber data. Bukan berati hanya dari guru, siswa, walimurid (tiga sumber) yang bisa dilakukan wawancara, namun bisa juga kepala sekolah, penilik sekolah, dsb. Pemilihan informan bisa lebih dari 3, bahkan cara pengambilan data bisa ditambahi triangulasi metode tau triangulasi teknik. Kedudukan triangulasi sebagai teknik untuk memeriksa keabsahan data 
memiliki fungsi penting untuk melihat keajegan data. Dengan demikian semakin banyak melakukan triangulasi dengan cara dan strategi apapun, bukan menjadi masalah, bahkan dianjurkan dalam penelitian kualitatif untuk mendapatkan data yang valid.

Setelah data dinyatakan valid, maka akan dilakukan analisis data. Salah satu teknik analisis data penelitian kualitatif yang seringkali digunakan oleh peneliti kualitatif adalah analisis data menurut Miles Huberman (1994) yakni reduksi data, penyajian atau pemaparan data, dan menarik kesimpulan. Oleh karena itu, dibuku ini penjelasan analisis kualitatif dipilih dan dibatasi pada analisis data model Miles Huberman, berikut penjelasannya:

a. Mereduksi data

Data yang terkumpul berupa data pengamatan, hasil tertulis, dan wawancara, atau yang lain dilakukan reduksi.Mereduksi data berfungsi untuk menajamkan, menggolongkan dan membuang informasi atau data dari lapangan yang tidak perlu serta mengorganisasikannya sehingga diperoleh data yang sesuai kebutuhan untuk menjawab pertanyaan penelitian.

b. Penyajian atau pemaparan data

Penyajian data dalam penelitian kualitatif bisa dilakukan dalam bentuk uraian singkat, bagan, hubungan antar kategori, tabel, grafik, matriks, dsb., sehingga 
terbentuk sekumpulan informasi yang terorganisasi dan terkategori.

c. Menarik simpulan

Setelah tahap reduksi dan penyajian data, penarikan kesimpulan dalam penelitian kualitatif bisa jadi masih berupa kesimpulan awal yang masih dapat berubah apabila tidak didukung dengan bukti-bukti kuat dan konsisten saat proses pengumpulan data. Tapi, apabila kesimpulan didukung oleh bukti-bukti yang konsisten dan kuat saat peneliti mereview kembali proses penelitian atau dengan melihat kondisi natural di lapangan, maka kesimpulan yang diperoleh dapat dikatakan kesimpulan akhir yang valid dan kredibel sesuai tujuan penelitian.

d. Contoh Penelitian Kualitatif

Penyusunan Laporan Penelitian Kualitatif umumnya mengikuti sistematika di bawah ini:

\begin{tabular}{|l|}
\multicolumn{2}{|c|}{ SISTEMATIKA LAPORAN PENELITIAN } \\
KUALITATIF \\
Abstrak \\
Kata Pengantar \\
Daftar Isi \\
BAB I (Pendahuluan) \\
Pendahuluan \\
Latar Belakang Masalah \\
Rumusan Masalah \\
Tujuan Penelitian \\
Manfaat Penelitian \\
BAB II (Kajian Pustaka) \\
\hline
\end{tabular}




\section{Lanjutan}

\section{SISTEMATIKA LAPORAN PENELITIAN KUALITATIF}

\section{BAB III (Metode Penelitian)}

Rancangan Penelitian

Latar dan Subjek Penelitian

Teknik Pengumpulan Data

Instrumen Penelitian

Analisis Data

\section{BAB IV (Hasil Penelitian dan Pembahasan)}

Hasil Penelitian

Pembahasan

BAB V (Penutup)

Simpulan

Saran

Daftar Pustaka

Berikut diberikan contoh laporan penelitian kualitatif di sekolah dasar tentang proses berpikir krtisis siswa sekolah dasar dalam memecahkan soal cerita matematika ditinjau dari gaya belajar. Penjelasan yang disajikan terbatas pada poin-poin penting saja yakni, latar belakang, kajian teori, metode penelitian, hasil dan pembahasan, simpulan dan saran penelitian.

\section{Latar Belakang}

Di era globalisasi seperti sekarang sangatlah mudah seseorang mendapatkan informasi, misal melalui media cetak, media elektronik, buku, atau internet. Di tengah informasi yang 
banyak tersebut tentu ada informasi yang benar dan tidak. Seseorang harus bisa menganalisa asumsi-asumsi ataupun pendapat yang melandasinya secara logis agar bisa memilah manakah informasi yang harus diambil sebagai informasi yang benar, tidak hanya itu seseorang harus bisa meyakinkan pendapatnya kepada orang lain, untuk melakukan hal demikian seseorang harus memiliki suatu kompetensi berpikir kritis. Menurut Siswono (2008) berpikir kritis termasuk salah satu perwujudan berpikir tingkat tinggi (high order thinking).

Baker (1991) menjelaskan berpikir kritis digunakan seseorang dalam proses kegiatan mental seperti mengidentifikasi pusat masalah dan asumsi dalam sebuah argumen, membuat simpulan yang benar dari data, membuat simpulan dari informasi atau data yang diberikan, menafsirkan apakah kesimpulan dijamin berdasarkan data yang diberikan, dan mengevaluasi bukti atau otoritas.

Berpikir kritis tidak berarti orang yang suka berdebat dengan mempertentangkan pendapat atau asumsi yang keliru, akan tetapi pemikir kritis juga dapat memberikan suatu solusi dari permasalahan dan pendapat yang disampaikan memiliki dasar yang tepat, rasional dan hati-hati. Sebagaimana menurut Ennis (2011) bahwa berpikir kritis merupakan berpikir logis atau masuk akal yang berfokus pada pengambilan keputusan tentang yang dipercaya dan dilakukan seseorang. 
Jufri (2013) menjelaskan para pemikir kritis selalu melewati beberapa tahap dalam tindakannya yakni merumuskan masalah, memberikan argumen, melakukan deduksi, melakukan induksi, melakukan evaluasi, lalu mengambil keputusan dan menentukan tindakan. Tahap ini memiliki kesamaan karakteristik dengan langkah-langkah pemecahan masalah menurut Polya (1973), yakni memahami masalah, merencanakan penyelesaian, melaksanakan perencanaan, dan memeriksa kembali. Nampak bahwa langkah-langkah penalaran yang dilakukan para pemikir kritis lebih logis, rasional, cermat, detail langkah demi langkah sesuai fokus permasalahan sebelum mengambil suatu keputusan. Berpikir kritis juga lebih kompleks dari berpikir biasa pada umumnya yang hanya memahami konsep atau masalah saja tanpa bisa mengidentifikasi dan mengeksplorasi masalah untuk mencari solusi lebih lanjut karena berpikir kritis membutuhkan kemampuan mental dan kemampuan intelektual yang lebih tinggi.

Meskipun kompetensi berpikir kritis memiliki manfaat yang sangat besar dan dibutuhkan di era globalisai, namun dalam pelaksanaan pendidikan khususnya dalam pembelajaran matematika di sekolah dasar, kompetensi berpikir kritis jarang diperhatikan guru dalam pembelajaran. Sebagaimana pendapat Fisher (2008) pembelajaran selama ini hanya mengajarkan tentang isi materi pelajaran dan mengesampingkan pengajaran 
keterampilan berpikir, sehingga sebagian siswa sama sekali tidak memahami keterampilan berpikir yang dibicarakan. Hal ini kontradiksi dengan Peraturan Menteri nomor 22 tahun 2006 yang mengamanatkan bahwa salah satu kemampuan berpikir yang hendaknya dimiliki oleh siswa mulai dari siswa Sekolah Dasar (SD) melalui pembelajaran matematika adalah berpikir kritis.

Dari hasil penelitian yang dilakukan oleh Arafiq (2014) tentang analisis kesalahan siswa MTs dalam memecahkan soal cerita berdasarkan tinjauan gaya belajar menunjukkan bahwa kesalahan yang dilakukan siswa bergaya belajar visual, auditori, maupun kinestetik meliputi kesalahan memahami soal, kesalahan dalam menyelesaikan soal, dan kesalahan dalam menuliskan simpulan. Hal ini selaras dengan pendapat Rabudianto (2015) bahwa masalah-masalah dalam bentuk soal cerita memang sulit dikerjakan oleh siswa, hal ini membutuhkan teknik dan strategi yang tidak didapat secara instan tetapi melalui latihan-latihan yang rutin. Untuk itu diperlukan kemampuan pemahaman bacaan, dapat memahami soal, mengetahui apa yang diketahui dan ditanyakan, membuat model matematika kemudian memecahkan masalah dengan rumus yang sesuai.

Dengan demikan apabila siswa pada jenjang menengah melakukan kesalahan dalam memecahkan masalah berbentuk soal cerita, hal ini mengindikasikan siswa pada jenjang 
sebelumnya yakni siswa Sekolah Dasar (SD) tentu mengalami hal yang serupa bahkan dimungkinkan mengalami kesalahan yang lebih kompleks.

Dari hasil observasi yang dilakukan peneliti di SDN Penatarsewu kabupaten Sidoarjo tepatnya di kelas VI diperoleh guru hanya menitikberatkan pembelajaran pada muatan kognitif hasil belajar siswa. Pembelajaran siswa diarahkan agar siswa mampu mengahafal konsep yang disampaikan guru dan memiliki hasil belajar yang tuntas pada aspek kognitif tanpa memperhatikan dan mengidentifikasi proses berpikir kritis siswa dalam pembelajaran saat siswa menyelesaikan soal ataupun memecahkan masalah. Demikian pula saat guru meminta siswa untuk memecahkan masalah matematika yang berbentuk soal cerita, evaluasi yang dilakukan dititikberatkan pada hasil belajar siswa tanpa mengidentifikasi kesulitan siswa dalam memecahkan soal cerita. Padahal siswa selama ini memiliki kesulitan dalam memahami ataupun memecahkan soal cerita. Oleh karena itu seharusnya guru memperhatikan dan mencoba untuk mengidentifikasi kesulitan siswa melalui proses berpikir kritis dalam melakukan penalaran secara lebih mendalam agar guru dapat melacak kesalahan dan kelemahan berpikir kritis siswa, sehingga guru dapat merancang pembelajaran yang dapat mengembangkan kompetensi berpikir kritis siswa. 
Setiap siswa memiliki cara belajar masing-masing yang berbeda dalam memahami informasi atau materi pelajaran, hal ini salah satunya dipengaruhi oleh perbedaan gaya belajar siswa. Menurut Irham dan Wiyani (2013) perbedaan gaya belajar pada siswa merupakan sesuatu yang dapat menjelaskan perbedaan-perbedaan siswa dalam proses belajar mengajar meskipun dalam kondisi dan proses pembelajaran yang sama.

Guru yang mengetahui proses berpikir kritis siswanya dalam memecahkan soal cerita ditinjau dari perbedaan gaya belajar siswa dalam menerima informasi, maka guru tersebut dapat mengidentifikasi penalaran serta kekurangan dan kesalahan dalam memecahkan soal cerita yang menjadi kesulitan siswanya selama ini. Sehingga guru dapat memilih dan menetukan metode pembelajaran yang lebih tepat bagi siswanya, tentu disertai dengan penyesuaian gaya belajar guru dengan gaya belajar siswanya pula. Tapi, apabila hal ini tidak dilakukan maka akan mengakibatkan proses belajar mengajar matematika tidak optimal yang berujung pada kemampuan berpikir tingkat tinggi termasuk berpikir kritis siswa tidak berkembang dengan baik.

Nasution (1987) menyatakan untuk mempertinggi efektivitas proses belajar mengajar memang perlu diadakan penelitian yang mendalam tentang gaya belajar siswa. Dengan demikian diperlukan suatu penelitian untuk mengidentifikasi 
proses berpikir kritis siswa dalam memecahkan soal cerita dengan tinjauan perbedaan gaya belajar siswa.

\section{Kajian Teori}

\section{Berpikir Kritis dalam Pemecahan Masalah}

Cukwuyenum (2013) menjelaskan berpikir kritis meliputi usaha seseorang dalam mengumpulkan, menafsirkan, menganalisis dan mengevaluasi informasi untuk sampai pada simpulan yang dapat diandalkan dan valid. Sementara itu Shapiro (2000) mengungkapkan berpikir kritis adalah suatu aktivitas mental yang berkaitan dengan penggunaan nalar yang menggunakan proses mental seperti memperhatikan, mengkategorikan, menyeleksi, dan memutuskan pemecahan suatu masalah.

Jadi berpikir kritis merupakan aktivitas mental seseorang dalam mengumpulkan, mengkategorikan, menganalisa, dan mengevaluasi informasi ataupun bukti agar dapat membuat suatu simpulan untuk memecahkan masalah.

Facione (dalam Peter, 2012) menjelaskan untuk mengetahui aktivitas mental siswa dalam berpikir kritis memecahkan suatu masalah dapat menggunakan langkahlangkah Identify, Define, Enumerate, Analyze, List, Self-Correct. Langkah-langkah ini dapat disingkat dengan IDEALS, berikut penjelasan masing-masing langkah tersebut.

a. Identify (I)

Menentukan ide pokok permasalahan yang dihadapi 
b. Define (D)

Menentukan fakta-fakta yang membatasi masalah, faktafakta permasalahan yang dimaksud meliputi apa saja yang diketahui, ditanya pada soal, serta informasi apa yang tidak digunakan atau tidak diperlukan.

c. Enumerate (E)

Menentukan atau mendaftar pilihan-pilihan jawaban yang mungkin dari masalah secara masuk akal.

d. Analyze (A)

Menganalisis pilihan jawaban apa yang terbaik untuk diambil sebagai suatu pilihan

e. List (L)

Menyebutkan alasan yang tepat mengapa pilihan jawaban yang dipilih terbaik

f. Self-Correct (S)

Mengecek kembali secara menyeluruh, apakah ada tindakan-tindakan untuk menyelesaikan soal yang terlewati.

\section{Pemecahan Masalah Berbentuk Soal Cerita Matematika}

Hudojo (1988) menjelaskan suatu pertanyaan akan merupakan masalah hanya jika seseorang tidak mempunyai aturan/hukum tertentu yang segera dapat dipergunakan untuk menemukan jawaban pertanyaan tersebut. Royani (2008) menyatakan soal cerita matematika merupakan soal-soal matematika yang menggunakan bahasa verbal dan umumnya berhubungan dengan kegiatan sehari-hari. Sedangkan Menurut 
Tim MKPBM Jurusan Pendidikan Matematika UPI (2001) tidak semua soal cerita merupakan masalah. Oleh karena itu soal cerita dikatakan masalah apabila soal tidak hanya mengandung unsur deskriptif dalam penyampaian bahasanya, akan tetapi juga memiliki unsur analisis dalam penggunaan aturan/hukum yang digunakan dalam pemecahannya.

\section{Berpikir Kritis dalam Pemecahan Masalah Berbentuk Soal}

\section{Cerita}

Dari uraian-uraian sebelumnya, dapat dibuat indikator berpikir kritis dalam memecahkan masalah berbentuk soal cerita berdasarkan langkah-langkah berpikir kritis IDEALS seperti yang tampak pada Tabel 3.1.

Tabel 3.1 Langkah-Langkah dan Indikator Berpikir Kritis

No Langkah-Langkah Berpikir

Kritis

1 (I) Identify

2 (D) Define

3 (E) Enumerate

4 (A) Analyze

5 (L) List

6 (S) Self-Correct
Indikator

Menyebutkan pokok permasalahan

Menyebutkan fakta-fakta yang membatasi masalah meliputi:

- Menyebutkan informasi-informasi yang dibutuhkan meliputi apa yang diketahui dan ditanyakan dalam soal.

- Menyebutkan informasi-informasi yang tidak digunakan Menyebutkan pilihan-pilihan cara dan jawaban yang masuk akal Menganalisis pilihan untuk memilih cara dan jawaban terbaik Menyebutkan alasan yang tepat atas cara dan jawaban terbaik yang dipilih Mengecek kembali secara menyeluruh proses jawaban

Sumber: Adaptasi (Peter, 2012)

\section{Gaya Belajar}

Gunawan (2006) gaya belajar adalah cara yang lebih disukai oleh seseorang dalam melakukan kegiatan berpikir, memproses dan mengerti informasi.DePoter dan Hernacki (2010:110-111), gaya belajar seseorang adalah kombinasi dari 
bagaimana seseorang menyerap, dan kemudian mengatur serta mengolah informasi.

Jadi dapat disimpulkan bahwa gaya belajar siswa adalah cara yang disukai siswa dalam belajar dan berpikir untuk menyerap, mengatur, dan mengolah informasi. Perbedaan ini dapat dilihat dari perilaku keseharian siswa yang konsisten.

DePoter dan Hernacki (2010:112) menyebutkan gaya belajar siswa meliputi gaya belajar visual, auditori, atau kinestetik (V-A-K). Karakteristik dari gaya belajar tersebut yakni siswa visual belajar melalui apa yang dilihat, siswa auditori belajar melalui apa yang didengar, dan siswa kinestetik belajar lewat gerakan dan sentuhan. Walaupun setiap siswa memiliki gaya belajar (V-A-K), akan tetapi sebagian besar siswa kecenderungan memiliki salah satu dari gaya belajar (V-A-K).

\section{Metode Penelitian}

Jenis penelitian ini adalah penelitian deskriptif dengan pendekatan kualitatif untuk mengidentifikasi proses berpikir kritis siswa SD dalam memecahkan masalah berbentuk soal cerita ditinjau dari perbedaan gaya belajar V-A-K (visual, auditori, kinestetik) siswa. Proses berpikir kritis tersebut dalam penelitian ini diidentifikasi berdasarkan langkah-langkah berpikir kritis IDEALS.

penelitian ini adalah 3 siswa kelas VI SDN Penatarsewu Tanggulangin Sidoarjo yang masing-masing memiliki gaya belajar V-A-K. Kriteria pemilihan adalah siswa yang memiliki 
gaya belajar $\mathrm{V}-\mathrm{A}-\mathrm{K}$ tertinggi. Jadi dalam penelitian ini terdiri dari 1 siswa yang memiliki gaya belajar visual tertinggi, 1 siswa yang memiliki gaya belajar auditori tertinggi, dan 1 siswa yang memiliki gaya belajar kinestetik tertinggi.

Instrumen penelitian ini sebagai berikut: 1) peneliti, Sugiyono (2013) menjelaskan peneliti adalah instrumen kunci dalam penelitian kualitatif. Hal ini berfungsi dalam menentukan fokus penelitian, memilih, melakukan pengumpulan data, menilai kualitas data, analisis data, menafsirkan data dan membuat simpulan dapat dilakukan dengan benar, 2) Tes Berpikir Kritis (TBK) yang terdiri dari 1 masalah berbentuk soal cerita pada materi luas jajargenjang, 3) Tes Gaya Belajar (TGB) yang diadaptasi peneliti dari instrumen gaya belajar oleh Chislett dan Chapman (2005) dengan menyesuaikan karakteristik berpikir dan bahasa pada siswa SD, dan 4) pedoman wawancara dibuat berdasarkan langkah-langkah berpikir kritis IDELAS.

Untuk mengamati proses berpikir menurut Siswono (2002) dapat diamati melalui proses cara mengerjakan tes dan hasil yang ditulis secara terurut. Selain itu ditambah dengan wawancara mendalam mengenai cara kerjanya. Dengan demikian teknik pengumpulan data dalam penelitian ini untuk mengamati proses berpikir kritis siswa dalam memecahkan masalah berbentuk soal cerita dilakukan dengan cara pemberian TBK pada, lalu dilakukan wawancara secara 
mendalam dengan menggunakan pedoman wawancara kepada dari hasil pekerjaan TBK. Selain itu diperlukan observasi proses berpikir kritis siswa. Observasi yang dilakukan peneliti mengacu pada pendapat Arikunto (2006) bahwa observasi dapat dilakukan degan tes, kuesioner, rekaman gambar, atau rekaman suara. Dalam penelitian ini peneliti melakukan observasi dengan menggunakan handphone untuk merekam aktivitas dan hasil wawancara, hal ini dilakukan agar setiap data hasil wawancara dan aktivitas tidak terlewatkan.

Analisis data penelitian dilakukan dengan cara reduksi data, pemaparan data, dan simpulan. Salah satu teknik untuk memeriksa kredibilitas suatu data adalah triangulasi (Sugiyono, 2013). Triangulasi yang digunakan adalah triangulasi teknik meliputi wawancara, observasi, hasil pekerjaan pada TBK.

\section{Hasil Penelitian}

Hasil proses berpikir kritis dalam memecahkan masalah berbentuk soal cerita berdasarkan langkah-langkah IDEALS dapat dilihat pada Tabel 3.2.

Tabel 3.2 Proses Berpikir Kritis Siswa Visual, Auditori, dan Kinestetik LangkahLangkah Berpikir

Visual

Kritis

(I) Identify

menyebutkan
pokok
permasalahan
berupa kertas
mana yang dapat
digunakan untuk
menutupi

menyebutkan pokok permasalahan berupa kertas yang dibutuhkan untuk menutupi kerangka layang-

\section{Kinestetik}

menyebutkan pokok permasalahan berupa luas layang-layang 


\section{Langkah- \\ Langkah \\ Berpikir \\ Kritis}

(D) Define

\section{Visual}

kerangka layanglayang

- menyebutkan apa diketahui yakni kerangka layanglayang, kertas berbeda warna dan ukuran

- menyebutkan apa yang ditanyakan yakni kertas mana yang dapat menutupi kerangka layanglayang.
(E)

Enumerate
- menyebutkan untuk mencari jawaban kertas yang mana dilakukan dengan cara

menggambar sketsa ukuran kertas lalu menempelkannya pada sketsa kerangka layang-
Auditori

Kinestetik

layang

- menyebutkan

- menyebutkan apa yang diketahui yakni kerangka apa yang diketahui yakni kerangka berbentuk layang-layang dan kertas layang-layang, kertas berbentuk bangun datar yang berbedabeda (persegi, persegipanjang, jajargenjang, segitiga, trapesium). berbentuk bangun datar (persegi, persegipanjang, jajargenjang, segitiga, trapesium), ukuran kerangka

- menyebutkan apa yang layang-layang dan kertas, warna kertas yakni kertas

- menyebutkan mana saja yang dapat digunakan apa yang ditanyakan yakni mencari untuk menutupi kerangka luas permukaan layang-layang layang-layang untuk menutupi kerangkangnya

- menyebutkan

- menyebutkan untuk mencari untuk mencari jawaban kertas yang paling jawaban luas yang diinginkan dapat dicari dengan cara menentukan luas masingmasing bangun datar, membuat sketsa bangun datar sesuai 


\section{Langkah- \\ Langkah \\ Berpikir \\ Kritis}

Visual

Auditori

Kinestetik

layang.

- menyebutkan

sketsa gambar

kertas dan

semua kertas bisa

kerangka.

digunakan untuk

- menyebutkan

menutupi

semua kertas

kerangka sebagai

mungkin dipilih

jawaban, akan

apabila belum

tetapi digambar

dicari luas dari

terlebih dahulu

kerangka

sketsanya

layang-layang

dan kertasnya

(A) Analyze

- memilih cara

- memilih cara terbaik hanya

terbaik adalah

dengan

dengan

cara

mensketsa

mencari luas

karena tidak ada

kertas

dan

cara lain yang

kerangka

terbaik.

menggunakan

- menjawab soal rumus.

Lalu

tidak tepat,

mencocokkan

jawaban yakni

masing-masing

luas kertas

kertas berbentuk persegipanjang.

(L) List

- Alasan memilih

- Alasan memilih

dengan

kerangka.

- menjawab

tepat kertas

yang dapat

menutupi

kerangka

adalah kertas

berbentuk

segitiga dan

persegi.

cara tersebut

cara tersebut

ukurannya, atau

dengan

menduga saja

kertas mana

yang dapat

menutupi.

- menyebutkan

semua kertas

mungkin dipilih

sebagai

jawaban

sebelum

mencari luas

kerangka dan

kertas

- memilih cara terbaik dan

paling cepat

dengan mencari

luas masing-

masing bangun

datar terlebih

untuk kemudian

mencocokkan

antara luas

kerangka dan

luas kertas, lalu

memilih luas

yang paling

tepat.

- menjawab

tepat kertas

yang dapat

menutupi

kerangka

adalah kertas

berbentuk

segitiga dan

persegi.

- Alasan memilih

cara tersebut 
Visual

Kritis

\section{Auditori}

\section{Kinestetik}

$$
\begin{aligned}
& \text { yakni mencari } \\
& \text { jawaban dengan } \\
& \text { menggunakan } \\
& \text { sketsa adalah } \\
& \text { cara yang satu- } \\
& \text { satunya dan } \\
& \text { paling mudah. }
\end{aligned}
$$

- Alasan memilih kertas berbentuk persegipanjang adalah kertas tersebut memiliki tampilan ukuran yang tampak lebih besar dibandingkan dengan tampilan kertas lain.
(S) SelfCorrect

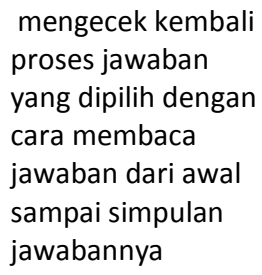

mengecek kembali proses cara dan jawaban yang digunakan dengan mengoreksi jawaban akhir perhitungan saja. yakni mensketsa bangun datar dari kerangka layang-layang dan kertas membutuhkan waktu yang lebih lama, sementara apabila menduga jawaban saja maka jawaban yang diperoleh kurang akurat.

- Alasan memilih kertas berbentuk segitiga dan persegi adalah kertas lain tidak memiliki ukuran kertas yang cukup untuk menutupi luas kerangka berdasarkan perhitungan rumus. mengecek kembali proses jawaban yang dipilih dengan cara membaca jawaban dari awal sampai akhir simpulan jawaban. 
Proses berpikir kritis siswa dalam memecahkan masalah berbentuk soal cerita yang nampak pada Tabel 2 bagi visual meliputi: 1) pada langkah Identify, dapat menyebutkan fokus permasalahan; 2) langkah Define, menyebutkan apa yang diketahui dan ditanya dalam soal; 3) langkah Enumerate; hanya menyebutkan satu cara, cara atau solusi pemecahan yang digunakan kurang tepat, jawaban yang diberikan tidak tepat karena terkecoh dengan informasi tidak penting berupa warna; 4) langkah Analyze, kurang dapat menganalisis permasalahan karena menggunakan cara yang kurang efektif sehingga berujung pada kesalahan jawaban; 5) langkah List, tidak memberikan alasan tepat atas cara dan jawaban yang digunakan; 6) langkah Self-Correct, mengecek kembali jawaban dengan cara mengecek jawaban dari awal sampai akhir (simpulan).

Proses berpikir pada auditori meliputi: 1) pada langkah Identify, dapat menyebutkan fokus permasalahan; 2) langkah Define, menyebutkan apa yang diketahui dan ditanya dalam soal; 3) langkah Enumerate; menyebutkan cara dan jawaban yang tepat, namun hanya memberikan satu cara pemecahan masalah; 4) langkah Analyze, dapat menganalisis cara dan jawaban yang dipilih.; 5) langkah List, menyebutkan alasan yang tepat atas cara dan jawaban terbaik yang dipilih; 6) langkah Self-Correct, mengecek kembali jawaban dengan cara mengecek jawaban akhir (simpulan) saja. 
Proses berpikir pada kinestetik meliputi: 1) pada langkah Identify, dapat menyebutkan fokus permasalahan; 2) langkah Define, menyebutkan apa yang diketahui dan ditanya dalam soal; 3) langkah Enumerate; menyebutkan semua kemungkinan cara dan jawaban tepat yang dapat digunakan; 4) langkah Analyze, dapat menganalisis semua cara dan jawaban yang dipilih.; 5) langkah List, menyebutkan alasan yang tepat atas cara dan jawaban terbaik yang dipilih; 6) langkah SelfCorrect, mengecek kembali jawaban dengan cara memeriksa dari awal sampai akhir jawaban.

\section{Pembahasan}

Berdasar uraian di atas tampak bahwa proses berpikir kritis visual, kinestetik, dan auditori dalam memecahkan masalah berbentuk soal cerita secara umum memiliki kesamaan pada langkah Identify dan Define, sementara memiliki perbedaan Enumerate, Analyze, List, dan Self-Correct. Perbedaannya terletak pada cara dan jawaban yang dipilih berdasarkan fakta dan alasan logis yang diberikan, perbedaan yang lain terletak pada ketelitian dalam memeriksa kembali jawaban yang diperoleh. kinestetik dapat dikatakan memiliki proses berpikir kritis lebih baik dibandingkan visual dan auditori pada langkah Enumerate, Analyze, List, dan SelfCorrect. Sementara, auditori dapat dikatakan memiliki proses berpikir kritis lebih baik dibandingkan visual. Temuan peneliti tersebut sesuai dengan penelitian kuantitatif yang dilakukan 
oleh Karim (2014) bahwa kemampuan berpikir kritis matematika siswa yang memiliki gaya belajar kinestetik $(\mu \mathrm{B} 3=$ $68,69)$ lebih tinggi daripada rerata kemampuan berpikir kritis siswa yang memiliki gaya belajar visual $(\mu \mathrm{B} 1=62,38)$ dan auditorial $(\mu \mathrm{B} 2=67,08)$.

Temuan lain yang didapat peneliti pada proses berpikir kritis siswa adalah ditemukan perbedaan proses gaya menjawab masalah pada langkah IDELAS (Identify, Define, Enumerate, Analyze, List, dan Self-Correct). visual cenderung melihat fokus permasahan dan menganalisa jawaban berdasarkan gambar. auditori seringkali membaca soal dan jawaban agar dapat menyebutkan fokus permasalahan, apa yang diketahui, apa yang ditanyakan, dan menganalisa permasalahan. Sementara kinestetik melakukannya dengan menggerak-gerakkan anggota badan dan pensil meski tidak menulis untuk menentukan fokus permasalahan. Hal ini mendukung pendapat DePorter \& Hernacki (2010) bahwa siswa seseorang visual mengingat dengan asosiasi visual, seseorang auditori berbicara kepada diri sendiri saat bekerja, dan seseorang kinestetik berorientasi pada fisik dan banyak bergerak.

Ada temuan menarik bahwa kinestetik menggunakan cara berupa rumus untuk mendukung jawaban yang diperoleh pada langkah Enumerate, Analyze, dan List. Padahal seharusnya kinestetik lebih suka menggunakan cara-cara yang berbasis 
eksplorasi atas kemungkinan jawaban tanpa mengutamakan rumus. Sebagaimana menurut DePorter\& Hernacki (2010) bahwa seseorang kinestetik belajar melalui memanipulasi dan praktik. Peneliti menduga, hal ini disebabkan karena pada saat proses pembelajaran siswa kelas VI SDN Penatarsewu Tanggulangin seringkali diajarkan materi-materi menggunakan rumus dengan mengesampingkan proses berpikir kritis dan perbedaan gaya belajar. Maka hendaknya guru-guru Sekolah Dasar khususnya guru kelas VI SDN Penatarsewu Tanggulangin menggunakan strategi, model, ataupun metode yang memperhatikan proses berpikir kritis dengan tidak menyamakan cara pengajaran atau pembelajaran bagi siswa yang memiliki gaya belajar visual, auditori, dan kinestetik agar siswa lebih kritis dalam memecahkan masalah soal cerita sesuai dengan gaya belajarnya.

\section{Simpulan}

Berdasarkan hasil dan pembahasan dapat disimpulkan bahwa proses berpikir kritis siswa visual, auditori, dan kinestetik pada langkah identify dan define memiliki kesamaan dalam memecahkan masalah berbentuk soal cerita. Perbedaan proses berpikir kritis tersebut paling menonjol terlihat pada langkah enumerate, analyze, list dan self-corret. Perbedaannya terletak pada cara dan jawaban yang dipilih berdasarkan fakta dan alasan logis yang diberikan, perbedaan yang lain terletak pada ketelitian siswa dalam memeriksa kembali jawaban yang 
diperoleh. Siswa kinestetik dapat dikatakan memiliki proses berpikir kritis lebih baik dibandingkan siswa visual dan auditori pada langkah Enumerate, Analyze, List, dan Self-Correct. Sementara, siswa auditori dapat dikatakan memiliki proses berpikir kritis lebih baik dibandingkan siswa visual. Siswa visual cenderung melihat fokus permasahan dan menganalisa jawaban berdasarkan gambar. Siswa auditori seringkali membaca soal dan jawaban agar dapat menyebutkan fokus permasalahan, apa yang diketahui, apa yang ditanyakan, dan menganalisa permasalahan. Sementara siswa kinestetik melakukannya dengan menggerak-gerakkan anggota badan dan pensil meski tidak menulis untuk menentukan fokus permasalahan.

\section{Saran}

Berdasarkan simpulan penelitian, saran yang dapat diberikan peneliti adalah hendaknya guru lebih memperhatikan proses berpikir kritis siswa dalam memecahkan masalah khususnya masalah berbentuk soal cerita saat pembelajaran berdasarkan perbedaan gaya belajar visual, auditori, kinestetik siswa karena masing-masing siswa yang memiliki perbedaan gaya belajar pasti memiliki karakteristik proses berpikir yang berbeda pula. Oleh karena itu siswa hendaknya diperhatikan proses berpikir kritisnya dan pembelajaran yang dilakukan berorintasi pada pemecahan masalah agar siswa terbiasa memecahkan masalah, sehingga diharapkan proses berpikir 
kritis siswa semakin baik dan meningkat. Dibutuhkan pula pemetaan cara belajar bagi siswa yang memiliki gaya belajar berbeda (Visual, Auditori, dan Kinestetik), misal siswa dengan gaya belajar visual dilatih pemecahan masalah dengan menyajikan masalah soal cerita berbentuk gambar-gambar, siswa auditori lebih sering diajak diskusi agar terbentuk pembelajaran interaktif secara lisan, dan siswa kinestetik tidak dibatasi ruang geraknya dalam memecahkan masalah.

\section{Daftar Pustaka}

Arafiq, Rasyid. 2014. Analisis Kesalahan Siswa MTs dalam Memecahkan Soal Cerita Bangun Ruang Sisi Datar Ditinjau Berdasarkan Gaya Belajar. Tesis. Surabaya: Pasca Sarjana Unesa tidak dipublikasikan.

Arikunto. 2006. Prosedur Penelitian: Suatu Pendekatan Praktik. Jakarta: Rineka Cipta.

Baker, M. 1991. Relationships Between Critical and Creative Thinking. Texas Tech University. Press.

Chislett, V. dan Chapman, A. 2005. VAK Learning Styels SelfAssessment Questionnaire.

Chukwuyenum, A.N. 2013. Impact of Critical Thinking of Performance in Mathematics Among Senior Secondary School Student in Lagos State. Journal of Research \& Metode in Education. Vol. 3 Issue 5, pp. 18-25.

Depdiknas. 2006. Peraturan Mendiknas No 22 Tahun 2006 Standar Isi. Jakarta: Depdiknas. 
DePorter, Bobbi \& Hernacki Mike. 2010. Quantum Learning: Membiasakan Belajar Nyaman dan Menyenangkan. Bandung: Kaifa.

Ennis R.H. 1996. Critical Thinking. New Jersey: Printice-Hall Inc.

Fisher, A. 2008. Berpikir Kritis Sebuah Pengantar. Jakarta: Erlangga.

Gunawan, A.W. 2006. Genius Learning Strategy. Jakarta: Gramedia Pustaka Utama.

Hudojo, Herman. 1988. Mengajar Belajar Matematika. Jakarta Depdikbud.

Irham, M dan Wiyani, N.A. 2013. Psikologi Pendidikan: Teori dan Aplikasi dalam Proses Pembelajaran. Yogyakarta: ArRuzz Media.

Jufri, Wahab. 2013. Belajar dan Pembelajaran Sains. Bandung: Pustaka Reka Cipta.

Karim, Abdul. 2014. Pengaruh Gaya Belajar dan Sikap Siswa Pada Pelajaran Matematika Terhadap Kemampuan Berpikir Kritis Matematika. Jurnal Formatif 4(3): 188-195, 2014

Nasution, S. 1987. Berbagai Pendekatan dalam Proses Belajar dan Mengajar. Jakarta: Bina Aksara.

Peter, E.E. (2012). Critical Thinking: Essence for Teaching Mathematics and mathematics problem solving skills. Departement of Mathematics and Computer Science Research. Vol. 5(3), pp. 39-43.

Polya, G. 1973. How To Solve It, A New Aspect of Mathematical Method. New Jersey: Princenton University Press.

Rabudianto, Fransiskus. 2015. Profil Berpikir Siswa SMP dalam Menyelesaikan Soal Cerita Matematika Ditinjau dari 
Perbedaan Kemampuan Matematika. Tesis. Surabaya: Pasca Sarjana Unesa tidak dipublikasikan.

Royani, Muhammad. 2008. Pendekatan Realistik dalam Soal Cerita Pada Buku Matematika Sekolah Dasar. Jurnal IImiah Kependidikan dan Kemasyarakatan. Banjarmasin: STKIP PGRI.

Shapiro(2000).Thinking About Mathematics: The Philosophy of Mathematics. New York: OXFORD University Press.

Siswono, Tatag Y.E. 2002. Proses Berpikir Siswa dalam Pengajuan Soal. Universitas Negeri Surabaya.

Siswono, T.Y.E. 2008. Model Pembelajaran Matematika Berbasis Pengajuan dan Pemecahan Masalah Untuk Meningkatkan Kemampuan Berpikir Kreatif. Surabaya: Unesa University Press.

Sugiyono. 2013. Metode Penelitian Pendidikan: Pendekatan Kuantitatif, Kualitatif dan R\&D. Bandung: Alfabeta.

Tim MKPBM Jurusan Pendidikan Matematika FMIPA UPI. 2001. Strategi Pembelajaran Matematika Kontemporer. Bandung: JICA.

\section{E. Latihan Membuat Penelitian Kualitatif}

Berikut diberikan beberapa kasus permasalahan yang dapat diangkat dalam sebuah penelitian kualitatfi yang sangat mungkin terjadi di sekolah. Pecahkan menurut pendapat anda dengan argumentasi yang logis dan ilmiah.

a. Setelah melakukan observasi di kelas SMP tertentu kelas VIII mata pelajaran IPA, mahasiswa sebagai peneliti mendapatkan data diantaranya adalah pembelajaran di 
kelas tersebut sudah menggunakan student center learning melalui strategi scientific learning, namun hasil belajar siswa masih di bawah KKM.

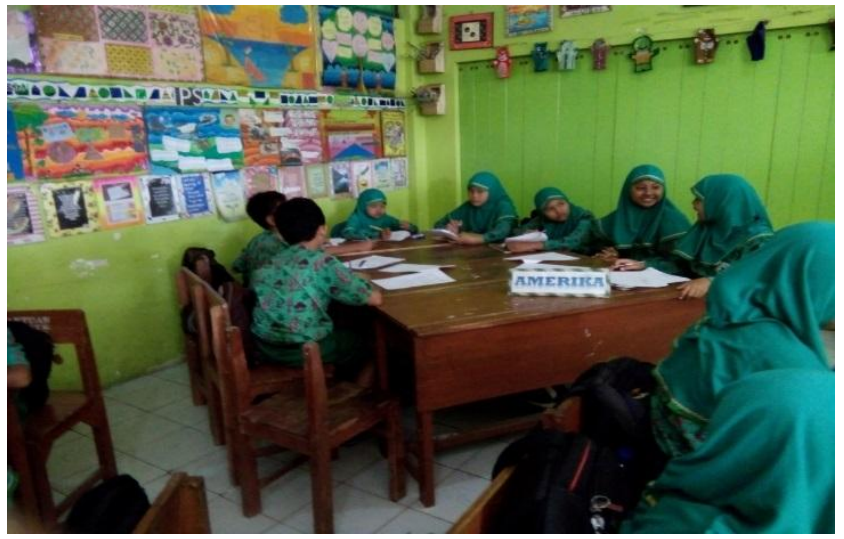

Guru selama ini tidak pernah ada yang mengamati bagaimana pelaksanaan pembelajarannya, bagaimana secara detail dan mendalam interaksi belajar siswa sehingga tidak mengetahui apakah memang sudah benar-benar menggunakan strategi scientific learning. Mengetahui hal ini, sebagai peneliti kualitatif, mahasiswa mengkaji literatur dan mendapatkan indikator interaksi belajar siswa adalah (1) Siswa memberikan bantuan dengan penjelasan, (2) Siswa memberikan bantuan tanpa penjelasan, (3) Siswa meminta bantuan, (4) Siswa menyampaikan ide atau pendapat. Bantulah mahasiswa tersebut untuk menentukan:

1) Fokus permasalahan 
2) Rumusan masalah dan tujuan penelitian yang sesuai (bisa asosiatif, deskriptif, dan komparatif)

3) Variabel yang akan dikaji lebih lanjut

4) Judul penelitian

5) Teknik pengumpulan data

b. Seorang peneliti ingin mengetahui proses berpikir siswa sekolah dasar kelas IV dalam memecahkan masalah matematika pada materi operasi perkalian. Menurut kajian teori yang dilakukan, Polya menyatakan pemecahan masalah dapat dilihat dari empat aspek Memahami masalah, merencanakan masalah, melaksanakan penyelesaian, dan memeriksa kembali. Peneliti merasa penelitian yang akan dilakukan masih terlalu luas cakupannya. Bantulah peneliti mempersempit cakupan penelitian dengan membatasi identifikasi kemampuan pemecahan masalah siswa dalam memecahkan masalah menggunakan tinjauan tertentu dan buatkan rumusan masalah, variable yang akan dikaji, judul penelitian, teknik pengumpulan data. 


\section{DAFTAR PUSTAKA}

Amir, M. F. (2015). Proses Berpikir Kritis Siswa Sekolah Dasar dalam Memecahkan Masalah Berbentuk Soal Cerita Matematika Berdasarkan Gaya belajar. JURNAL MATH EDUCATOR NUSANTARA: Wahana Publikasi Karya Tulis IImiah di Bidang Pendidikan Matematika, 1(2).

Amir, M. F., \& Kurniawan, M. I. (2016). Penerapan Pengajaran Terbalik untuk Meningkatkan Hasil Belajar Mahasiswa PGSD UMSIDA pada Materi Pertidaksamaan Linier. PEDAGOGIA: Jurnal Pendidikan, 5(1), 13-26.

Arikunto, S. (2010). Prosedur Penelitian Pendidikan. Jakarta: PT Rineka Cipta.

Miles, M. B., \& Huberman, A. M. (1994). Qualitative data analysis (ed.). Thousand Oak: CA: Sage.

Moleong, J. (2009). Lexy. Metodologi Penelitian Kualitatif. Bandung: PT Remaja Rosdakarya.

Mulyasa, E. (2012). Praktik Penelitian Tindakan Kelas. Bandung: PT Remaja Rosdakarya.

Siswono, T. Y. E. (2008). Mengajar Dan Meneliti Panduan Penelitian Tindakan Kelas Untuk Guru Dan Calon Guru. Surabaya: Unesa Press.

Sugiyono, P. D. (2013). Metode Penelitian Manajemen. Bandung: ALFABETA, CV. 


\section{BAB IV}

\section{METODOLOGI PENELITIAN TINDAKAN KELAS (PTK)}

\section{A. Paradigma PTK}

Pernahkan Anda sebagai guru mengalami sebuah situasi dimana anda merasa mengajar sudah sangat baik dengan selalu hadir di saat jam mengajar; melaksanakan pengajaran sesuai Program Tahunan (prota), Program Semester (promes), silabus, Rencana Pelaksanaan Pembelajaran (RPP); melaksanakan program remedial; melaksanakan evaluasi. Akan tetapi hasil dan proses belajar tidak sesuai dengan yang diharapkan.

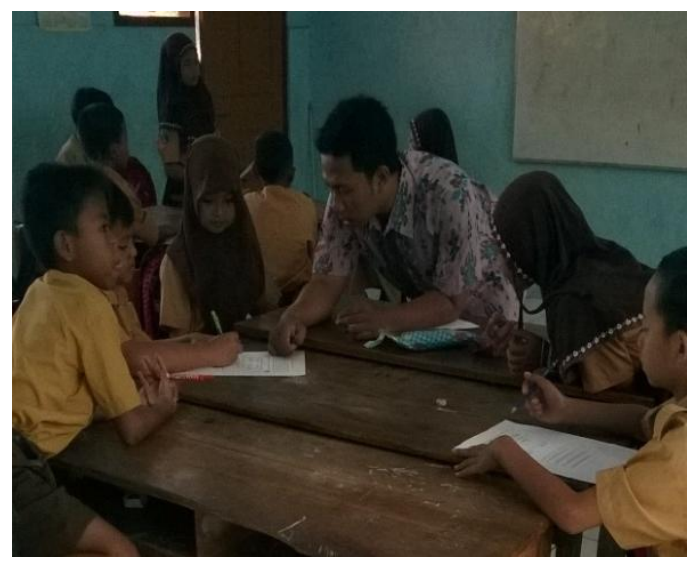

Pernahkan Anda pula ketika mengalami situasi demikian melakukan evaluasi pembelajaran dan melakukan tindakan dengan mengganti strategi, model atau metode pembelajaran ataupun menggunakan media pembelajaran. Sesungguhnya apa yang Anda lakukan ini merupakan suatu bentuk penelitian. Namun, Anda belum melakukannya secara ilmiah dengan 
menggunakan prosedur yang sistematis dan objektif sesuai kaidah-kaidah ilmiah. Pada dasarnya penelitian merupakan suatu aktivitas pendekatan ilmiah untuk mengkaji suatu masalah dan menemukan jawaban terhadap suatu masalah melalui prosedur-prosedur ilmiah yang sistematis dan objektif. Ilmiah artinya harus memenuhi syarat atau kaidah ilmu pengetahuan. Sistematis artinya penelitian memiliki prosedur identifikasi masalah sampai pada penyelesaian masalah yang dibuktikan dengan laporan penelitian. Objektif artinya penelitian diperoleh dari fakta-fakta empiris penelitian atau proses sampai hasil selama melakukan penelitian.

Penelitian yang dapat dilakukan oleh seorang pengajar (guru dan dosen) dengan tidak mengganggu proses pembelajaran yang sudah direncakan atau dengan kata lain pengajar dapat melakukan pembelajaran dan penelitian secara beriringan. Agar penelitian bisa dilakukan seperti itu, maka penelitian harus dilakukan sesuai kebutuhan, kemampuan, masalah yang muncul sehari-hari di kelas. Penelitian yang dapat dilakukan adalah Penelitian Tindakan Kelas (PTK) atau sering disebut classroom action research.

Di Indonesia Classroom Action Research (CAR) memang popular dengan namaPenelitian Tindakan Kelas (PTK), tidak hanya CAR sebenarnya PTK memiliki beberapa nama lain yakni classroom research, self-reflective enguiry, ataupun action research.Penelitian ini menjadi tolak ukur profesionalisme 
tenaga pendidik (guru) dalam rangka meningkatkan kualitas pembelajaran yang dapat bermuara pada kualitas hasil belajar siswanya. Pada hakikatnya yang paling mengetahui permasalahan yang terjadi di kelas adalah guru itu sendiri, sehingga dengan adanya PTK guru dapat secara langsung memberikan solusi sekaligus menerapkannya dengan berkolaborasi pihak-pihak tertentu, misal mahasiswa atau dosen. Dengan adanya PTK guru juga dapat mengembangkan hasil pemikirannya sendiri atau orang lain yang tentunya memiliki setting permasalahan dan solusi yang serupa.

Begitu pentingnya PTK dilakukan oleh guru untuk memperbaiki kualitas pembelajaran, sehingga Pemerintah Indonesia membuat aturan kewajiban guru melakukan penelitian yang diatur dalam UU RI No. 20 tentang Sistem Pendidikan Nasional, Bab XI, pasal 39. Kebijkan ini mengatur bagi guru yang ingin menaikkan pangkat atau golongan sebagai guru professional.

Berdasarkan pengalaman penulis selama memberi pelatihan PTK bagi guru-guru termasuk mengampu matakuliah metode penelitian. Banyak diantara guru yang pada dasarnya memahami PTK, namun kebingungan saat mengidentifikasi masalah dan menemukan solusi yang tepat. Tidak hanya itu, hampir seluruh guru belum bisa membuat laporan penelitian yang sistematis, ilmiah, dan objektif. Hal yang sering terjadi adalah adanya kesalahan dalam mengidentifikasi permasalahan 
karena lebih banyak mendasarkan argumentasi pada komentar-komentar pribadi dan kurangnya mengkaji teori atau hasil-hasil penelitian terdahulu sehingga terjadi perlakuan atau kontaminasi data. Tidak sedikit juga, guru atau mahasiswa calon guru yang memahami PTK secara teoritis, namun dalam tataran aplikatif sulit untuk mengawali dan melakukan tindakan di kelas. Melalui BAB IV ini diharapkan kesenjangan antara teori dan praktik PTK dapat terselesaikan, karena pembaca akan diberikan penjelasan mengenai bagaimana mengidentifikasi permasalahan di kelas dan melaksanakan rencana dari solusi penyelesaian hasil refleksi dengan diberikan contoh-contoh yang aplikatif sampai pada laporan PTK.

\section{B. Karakteristik PTK}

Penelitian Tindakan Kelas (PTK) berawal dari gagasan seorang sosiolog dari Amerika yang bekerja pada bidang sosial kemanusiaan bernama Kurt Lewin. Dalam perkembangannya PTK digunakan pendidik untuk menyelesaikan masalah-masalah proses pembelajaran yang terjadi di kelas. Namun makna "Kelas" pada kata PTK bukan berarti penelitian atau tindakan yang dilakukan hanya terbatas di ruang lingkup kelas yang tertutup. Namun, bisa juga pendidik memberi tindakan berupa tugas di rumah, siswa melakukan praktek di laboratorium, atau melakukan karya wisata di luar sekolah. 
Mulyasa (2012) menyebutkan PTK terdiri dari tiga kata Penelitian, Tindakan, dan Kelas.

a. Penelitian adalah kegiatan mencermati suatu objek dengan menggunakan objek tertentu untuk menggali dan mendapat informasi tertentu sehingga dapat menyelesaikan masalah suatu hal atau meningkatkan mutu suatu hal tertentu yang tentunya menarik minat peneliti.

b. Tindakan adalah suatu gerak tertentu yang disengaja dilakukan dengan tujuan tertentu, dalam penelitian berbentuk rangkaian siklus kegiatan yang melibatkan peserta didik.

c. Kelas yang dimaksud dalam hal ini bukan hanya terbatas pada ruang kelas, namun mengandung pengertian yang lebih umum dalam bidang pendidikan dan pengajaran bahwa kelas adalah sekelompok peserta didik dalam waktu yang sama menerima pelajaran tertentu dari guru yang sama pula.

Lebih lanjut Mulyasa (2012) menyatakan pengertian di atas membawa kita dalam pengertian bahwa penelitian tindakan kelas merupakan suatu upaya atau usaha yang sengaja dilakukan oleh guru dengan cara mencermati kegiatan belajar sekelompok peserta didik dengan memberikan suatu tindakan. Tindakan tersebut bisa dilakukan oleh guru, guru bersama dengan siswa, atau siswa dibawah arahan dan bimbingan guru agar tercipta perbaikan kualitas pembelajaran. 
Sementara Ekawarna mengemukakan penelitian tindakan kelas adalah penelitian yang dilakukan oleh guru dalam kelas. Penelitian ini pada hakikatnya merupakan rangkaian "risettindakan-riset-tindakan....dst." yang dilakukan secara siklik untuk memecahkan masalah yang muncul di kelas sampai masalah tersebut terselesaikan.

Siswono (2008) menjelaskan penelitian tindakan kelas adalah salah satu jenis penelitian yang berupaya untuk memecahkan masalah-masalah yang berkaitan dengan proses pembelajaran oleh guru di kelasnya sendiri. PTK memiliki karateristik yang membedakan dengan penelitian lain sebagai berikut.

a. Masalah PTK muncul dari guru

b. Pengumpulan data dari praktek sendiri

c. Dilakukan di kelas dan fokusnya pada kegiatan pembelajaran yang berupa interaksi perilaku guru dan siswa

d. Perbaikan dilakukan secara bertahap dan terus menerus selama kegiatan penelitian, sehingga terdapat sikulus yang sistematis.

Adapun Prinsip-prinsip pelaksanaan PTK

a. Pelaksanaan PTK tidak boleh mengganggu atau menghambat kegiatan pembelajaran

b. Metode yang digunakan harus reliabel artinya terencana dengan cermat sehingga tindakan dapat dirumuskan dalam suatu hipotesis tindakan yang dapat diuji di lapangan. 
c. Permasalahan yang dipilih harus menarik, nyata, tidak menyulitkan, dapat dipecahkan, berada dalam jangkauan peneliti untuk melakukan perubahan dan peneliti merasa terpanggil untuk mengingkatkan diri

d. Pengumpulan data tidak mengganggu atau menyita waktu terlalu banyak

e. Metode dan teknik yang digunakan tidak terlalu menuntut baik dari kemampuan guru itu sendiri ataupun segi waktu.

f. Harus memperhatikan etika penelitian, tatakrama penelitian dan rambu-rambu pelaksanaan yang berlaku umum seperti yang diteliti harus dihormati kerahasiannya, semua pihak yang terkait setuju dengan prinsip-prinsip penelitian, harus ada laporan, dll

g. Kegiatan penelitian pada dasarnya harus merupakan gerakan yang berkelanjutan, karena cakupan peningkatan dan pengembangan sepanjang waktu menjadi tantangan.

Tabel 4.1 Perbedaan PTK dan non PTK

\begin{tabular}{|c|l|l|l|}
\hline No. & \multicolumn{1}{|c|}{ Aspek } & \multicolumn{1}{c|}{ Non PTK } & \multicolumn{1}{c|}{ PTK } \\
\hline 1 & $\begin{array}{l}\text { Sumber } \\
\text { Masalah }\end{array}$ & $\begin{array}{l}\text { Masalah dan hasil } \\
\text { pengematan } \\
\text { pihak lain } \\
\text { (induktif- } \\
\text { deduktif) }\end{array}$ & $\begin{array}{l}\text { Masalah yang } \\
\text { dirasakan dan } \\
\text { dihadapi peneliti } \\
\text { sendiri dalam } \\
\text { melaksanakan } \\
\text { tugas } \\
\text { (diagnosisis) }\end{array}$ \\
\hline 2 & Tujuan & $\begin{array}{l}\text { Menguji } \\
\text { hipotesis, } \\
\text { membuat }\end{array}$ & $\begin{array}{l}\text { Melakukan } \\
\text { perbaikan, } \\
\text { peningkatan }\end{array}$ \\
\hline
\end{tabular}




\begin{tabular}{|c|c|c|c|}
\hline No. & Aspek & Non PTK & PTK \\
\hline & & $\begin{array}{l}\text { generalisasi } \\
\text { mencari } \\
\text { penjelasan }\end{array}$ & $\begin{array}{l}\text { dalam } \\
\text { pembelajaran }\end{array}$ \\
\hline 3 & $\begin{array}{l}\text { Manfaat/ } \\
\text { Kegunaan }\end{array}$ & $\begin{array}{l}\text { Tidak langsung } \\
\text { dan sifatnya } \\
\text { sebagai saran }\end{array}$ & $\begin{array}{l}\text { Langsung dapat } \\
\text { dirasakan dan } \\
\text { dinikmati oleh } \\
\text { penelitian }\end{array}$ \\
\hline 4 & Teori & $\begin{array}{l}\text { Digunakan } \\
\text { sebagai dasar } \\
\text { perumusan } \\
\text { hipotesis atau } \\
\text { teori } \\
\text { membangun }\end{array}$ & $\begin{array}{l}\text { Digunakan } \\
\text { sebagai dasar } \\
\text { untuk memilih } \\
\text { tindakan/solusi } \\
\text { tindakan } \\
\text { berikutnya }\end{array}$ \\
\hline 5 & Metodologi & $\begin{array}{l}\text { Menuntut } \\
\text { paradigma } \\
\text { penelitian yang } \\
\text { jelas. } \\
\text { Langkah kerja } \\
\text { punya } \\
\text { kecenderungan } \\
\text { linier. } \\
\text { Analisis dilakukan } \\
\text { setelah data } \\
\text { terkumpul }\end{array}$ & $\begin{array}{l}\text { Bersifat fleksibel } \\
\text { Langkah kerja } \\
\text { bersifat siklik dan } \\
\text { setiap siklik } \\
\text { terdiri tiga } \\
\text { tahapan. } \\
\text { Analisis terjadi } \\
\text { saat proses } \\
\text { setiap siklus }\end{array}$ \\
\hline 6 & Motivasi & kebenaran & tindakan \\
\hline 7 & Sasaran & $\begin{array}{l}\text { Sampel } \\
\text { representatif } \\
\text { (khusus) }\end{array}$ & Kasus khusus \\
\hline 8 & $\begin{array}{l}\text { Hasil } \\
\text { Penelitian }\end{array}$ & $\begin{array}{l}\text { Pengetahuan, } \\
\text { prosedur, atau } \\
\text { materi teruji }\end{array}$ & $\begin{array}{l}\text { Siswa belajar } \\
\text { lebih baik (proses } \\
\text { dan produk) }\end{array}$ \\
\hline
\end{tabular}

Sumber: Siswono (2008) 
Dilihat dari struktur metode penelitian, PTK tergolong dalam penelitian kualitatif. Meskipun dimungkinkan data yang didapatkan seorang peneliti bisa berupa data kuantitatif maupun data kaulitatif. PTK tidak sama dengan penelitian lain yang bertujuan menguji hipotesis dan mendukung dan menolak teori yang bersifat general. PTK lebih bertujuan untuk memperbaiki atau meningkatkan kualitas kinerja, hasil PTK tidak untuk digeneralisasi karena sifatnya yang real (nyata) sesuai permasalahan di kelas.

Dari serangkain paparan mengenai PTK di atas, pada dasarnya dapat didefinisikan PTK adalah Penelitian yang dilakukan oleh pendidik (bisa kolaboratif) untuk menyelesaikan permasalahan-permasalahan di kelas secara objektif, sistematis, prosedural, dan ilmiah sampai masalah tersebut terpecahkan sehingga kualitas atau mutu pembelajaran dapat menjadi lebih baik dari sebelumnya.Kolaboratif dimaknai dengan kerjasama dengan pihak-pihak tertentu, misal mahasiswa, dosen, praktisi, akademisi, dsb. Pernyataan ini secara eksplisit, mahasiswa kita pada pemahaman mahasiswa sebagai akademisi yang tertarik dengan PTK dan bersama-sama dengan guru untuk menyelesaikan permasalahan di kelas, tidak menyalahi kaidah penelitian. Jadi mahasiswa diperbolehkan mengambil tugas akhir skripsi dengan mengambil penelitian tindakan kelas selama berkolaborasi dengan guru. 


\section{Mengidentifikasi Macam Penelitian Tindakan Kelas}

PTK memiliki berbagai macam model atau desain penelitian diantaranya model PTK menurut Kurt Lewin, Kemmis \& McTaggart, John Elliott, dan Dave Ebbutt.Akan tetapi yang paling sering dan umum digunakan adalah model dari Kurt Lewin (orang yang pertama kali memperkenalkan PTK). Model Kurt Lewin memiliki komponen pokok yaitu perencanaan (planing), tindakan (acting), pengamatan (observing), refleksi (reflecting). Hubungan komponen PTK digambarkan dengan diagram ini

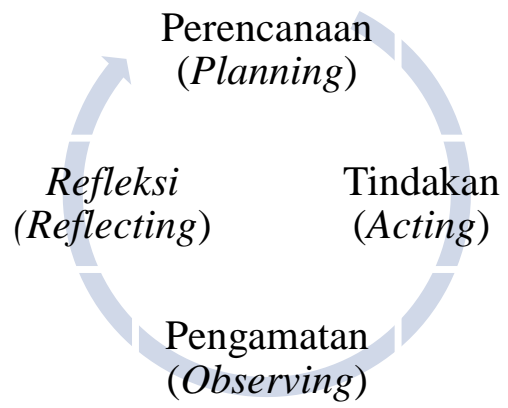

Diagram 4.1 Hubungan Komponen PTK Menurut Kurt Lewin Hubungan komponen PTK Kurt Lewin selanjutnya dikembangkan oleh Kemmis \& McTaggart dengan model di bawah ini. 


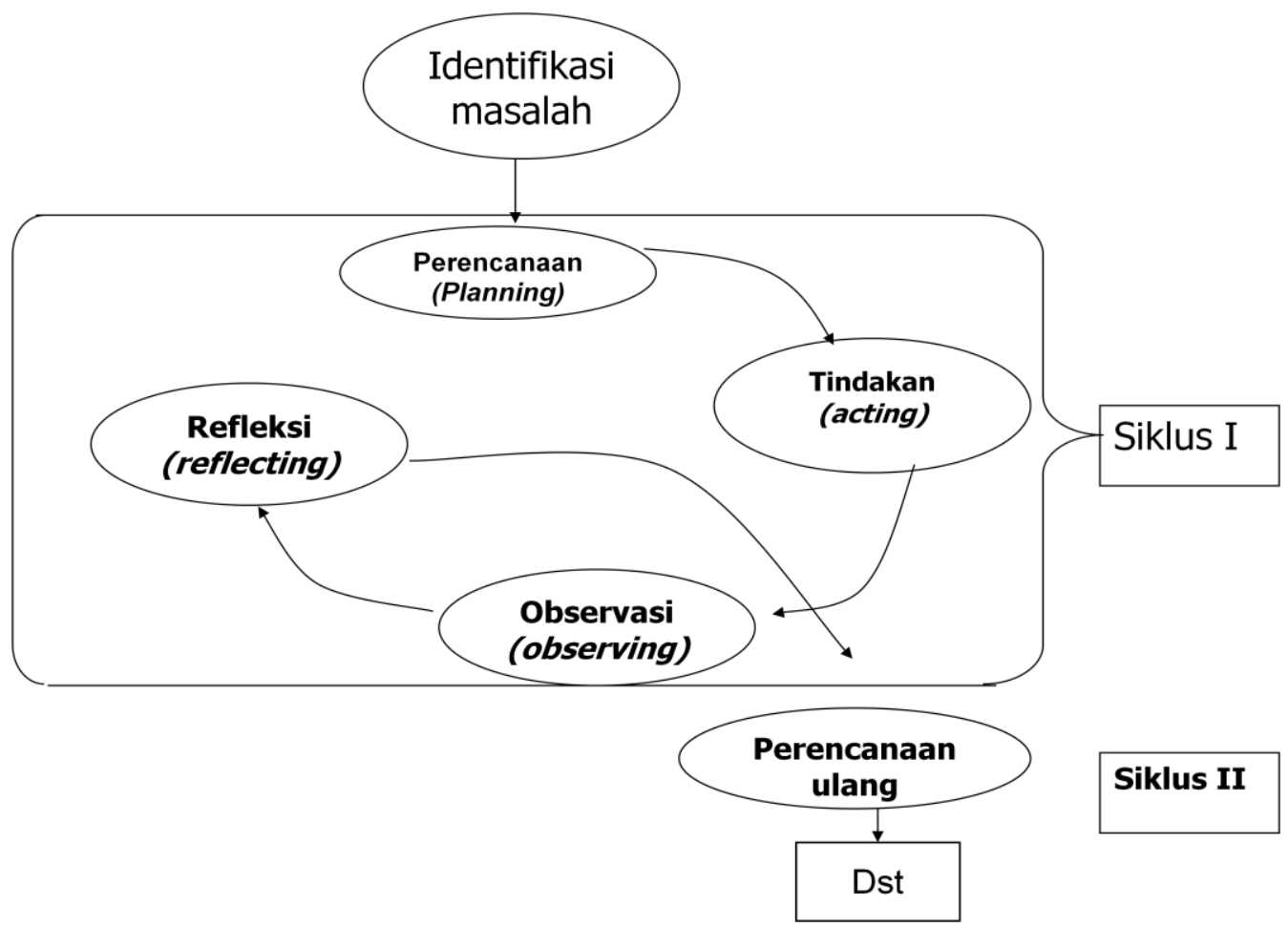

Diagram 4.2 Model PTK 1 Menurut Kemmis \& McTaggart

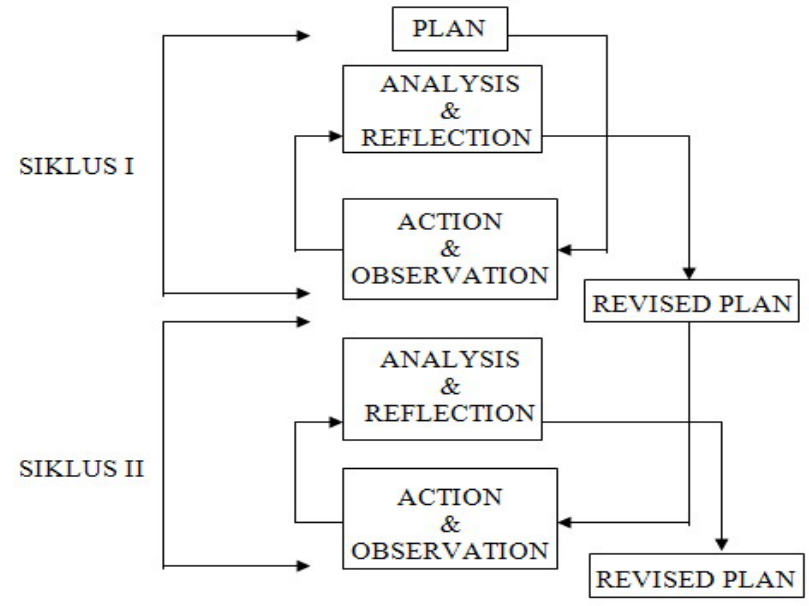

Diagram 4.3 Model PTK 2 Menurut Kemmis \& McTaggart 
Ada pula model PTK lain menurut John Elliot $t$ dan Dave Ebbutt. Di Indonesia pada umumnya memang sampai sekarang masih jarang peneliti, pendidik (guru dan dosen), ataupun praktisi yang memakai model ini karena dipandang "mungkin" terlalu rumit.

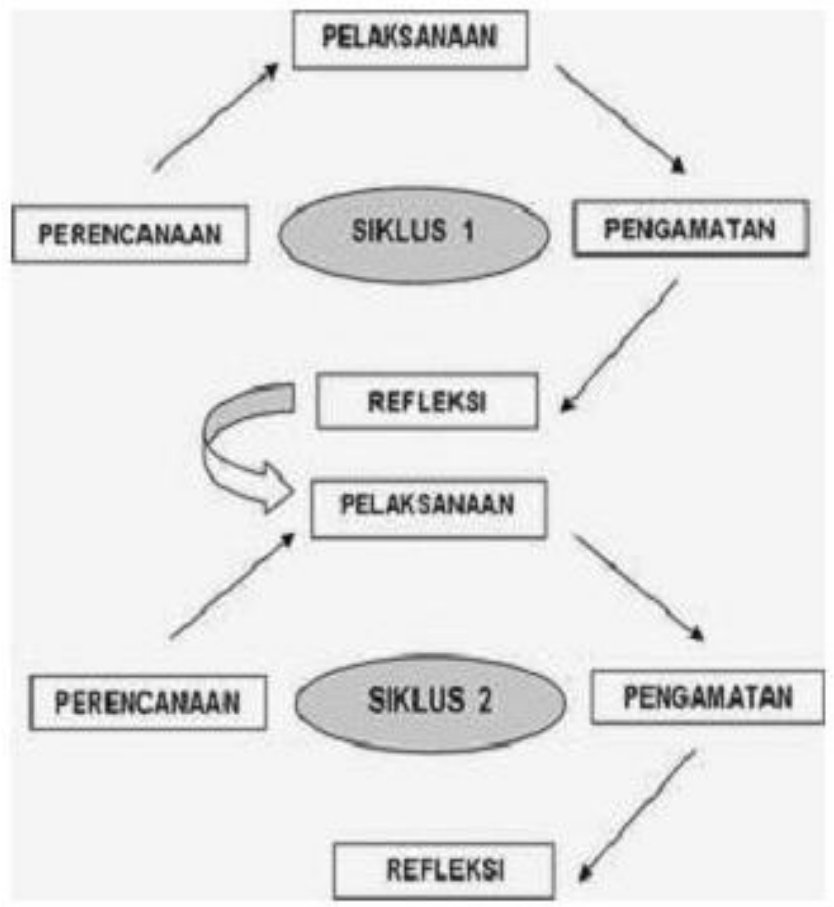

Diagram 4.4 Model PTK Menurut John Elliott 


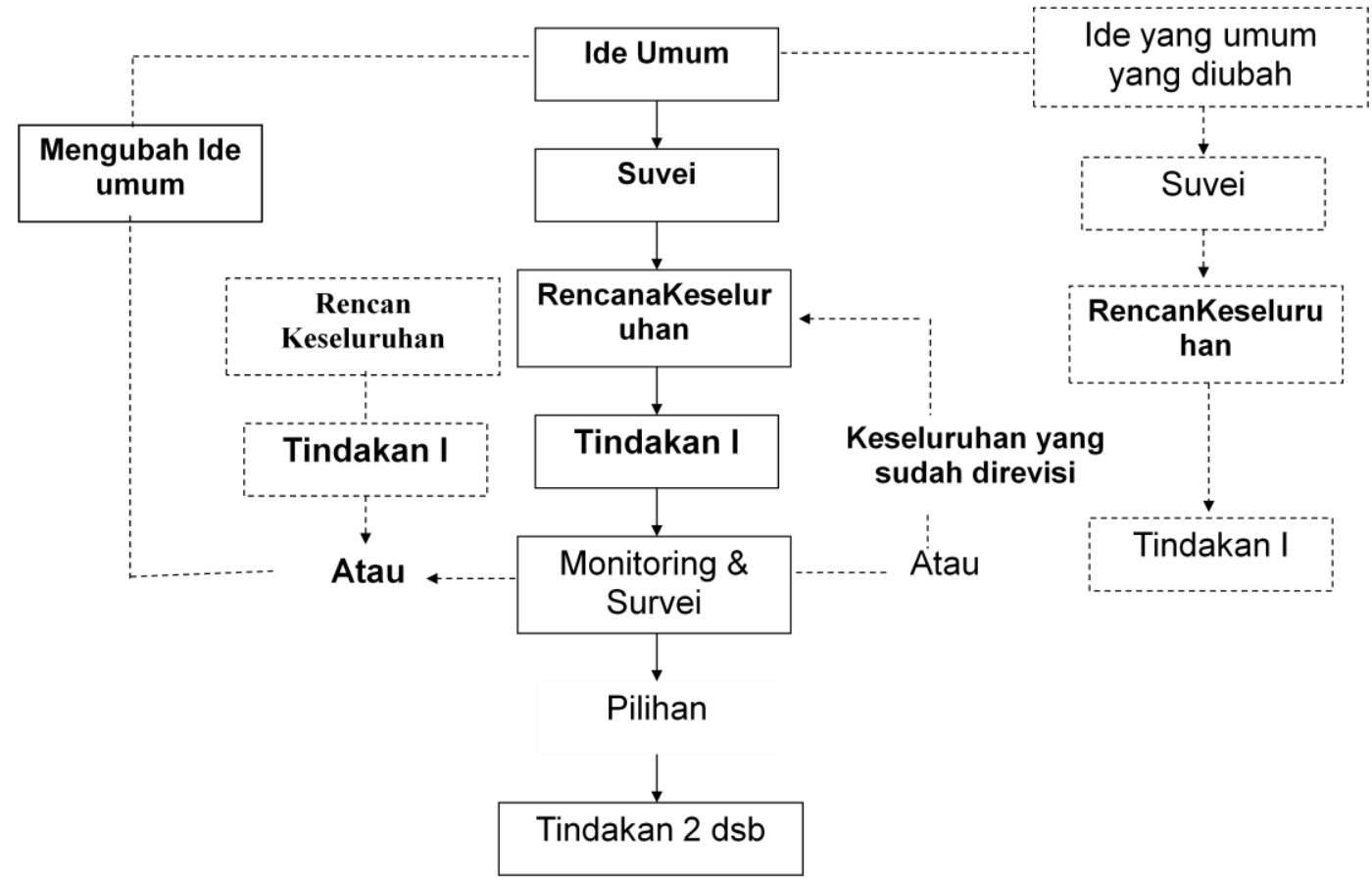

Diagram 4.5 Model PTK Menurut Dave Ebbutt

Pada intinyamodel-model PTK di atas terdiri dari perencanaan (Planning), tindakan (acting), pengamatan (observing), dan refleksi (reflecting). Model-model itu memiliki benang merah prosedur penelitian tindakan kelas, yakni:

a. Perencanaan (Planning)

Perencanaan meliputi kegiatan awal yang dilakukan sebelum terjun ke lapangan. Kegiatan ini meliputi instrumen penelitian, perangkat pembelajaran (Silabus, RPP, Lembar Kerja), buku siswa, maupun lembar penilaian. Kegiatan lain adalah mendiagonsis siswa, validasi instrumen dan perangkat pembelajaran minimal dari sisi konstruk dan isi, 
uji keterbacaan, menyiapkan alat dan bahan, media, mengatur strategi pelaksanaan penelitian bersaman tim peneliti, serta jadwal pelaksanaan kegiatan.

b. Tindakan (acting) dan Pengamatan (observing)

Pada tahap ini dilakukan implementasi pembelajaran di kelas, sekaligus pengamatan. Guru melakukan kegiatan pengajaran dan pengamat melakukan pengamatan sesuai fokus atau maalah penelitian.

c. Refleksi (reflecting)

Peneliti melakukan pembandingan antara hasil dari tes, angket, atau lembar observasi terhadap indikator keberhasilan. Peneliti melakukan analisis dan telaah terhadap hasil itu, serta memberikan rekomendasi untuk tindak lanjut perbaikan perencanaan apabia pada siklus ini indikator keberhasilannya tidak tercapai.

\section{Praktik Melakukan PTK}

Siapapun sebagai seorang pendidik tentu mengetahui dan merasakan adanya masalah di kelas. Namun seringkali banyak yang kesulitan untuk mengawali Penelitian Tindakan Kelas agar masalah-masalah yang ada dapat dipecahkan. Kesulitan ini terkadang berdampak "enggannya" kita sebagai pendidik untuk melakukan PTK. Memang persiapan matang dalam melaksanakan PTK menjadi kebutuhan setiap pendidik di tengah jadwal aktivitas mengajar dan aktivitas lain tentunya. 
Hal yang tidak boleh dilupakan adalah utamanya kewajiban pendidik adalah mengajar, tapi penelitian termasuk PTK dapat dilakukan seiring melakukan pengajaran tersebut karena pada prinsipnya PTK dilakukan oleh pendidik saat mengajar sambil meneliti. Apabila prinsip ini disadari dan dijalankan dengan penuh amanah, maka setiap permasalahan yang muncul di kelas tentu dapat diselesaikan secara periodik dan pendidik tetap dapat mengajar dengan tidak takut terganggu adanya jadwal mengajar yang berubah tidak sesuai dengan perencanaan silabus ataupun promes (program semester) dan prota (program tahunan).Berikut dijelaskan langkah-langkah awal persiapan sampai pada pelaksanaan PTK.

a. Mengidentifikasi dan Menganalisis Masalah

Pemahaman akankriteria masalah dalam penelitian juga harus diketahui, Tidak selamanya masalah di kelas diselesaikan dengan menggunakan PTK, sebagai pendidik harus memastikan dan menimbang dengan matang apakah dia mampu melaksanakan PTK dengan topik yang akan diangkatnya. Termasuk juga harus dipahami masalah ketidaktersediaan sarana dan prasana kelas tidak bisa dilakukan tindakan dengan PTK. Misal seorang guru berpendapat siswa kurang antusias dalam pembelajaran karena spidol yang digunakan guru tidak variatif warnanya. Jika permasalahannya seperti ini guru tinggal membelikan spidol berwarna-warni, bisa lewat uang pribadi atau 
memintakan ke Tata Usaha sekolah. Agar lebih memahami cara mengidentifikasi dan menganalis permasalahan di kelas, simaklah contoh di bawah ini.

"Bu Ida seorang guru matapelajaran matematika di Sekolah Dasar. Bu Ida bingung nilai matematika siswanya yang tidak kunjung mengalami perbaikan meskipun beberapa metode sudah seringkali dicobanya. Pandangan siswa tentang matematika adalah mata pelajaran yang menjenuhkan. Interaksi belajar antar siswa dan guru masih belum optimal. Rata-rata nilai siswa pada materi operasi pembagian pecahan adalah 45, sementara KKM (Kriteria Ketuntasan Minimal) disekolah 70. Hasil pekerjaan siswa dan hasil wawancara dengan beberapa siswa menunjukkan siswa tidak bisa memahami soal dengan baik, kalaupun memahami siswa tidak bisa merencanakan penyelesaian soal apalagi melaksanakan penyelesaian (misal tidak bisa menggunakan rumus dengan tepat), seringkali siswa ceroboh tidak memeriksa kembali hasil pekerjaannya sehingga hasil akhir jawabannya salah."Masalah-masalah yang dapat diidentifikasi di atas adalah:

a) Respon siswa terhadap matematika negatif

b) Aktivitas siswa masih cenderung berpusat pada guru

c) Hasil belajar siswa rendah, di bawah KKM

d) Siswa tidak memahami soal dengan baik

e) Siswa tidak bisa membuat perencanaan solusi dari soal 
f) Siswa tidak bisa menyelesaikan perencanaan

g) Siswa tidak teliti memeriksa kembali hasil pekerjaannya

Dalam PTK, peneliti bisa memilih masalah mana yang lebih utama mendesak dan penting untuk dipecahkan karena dimungkinkan masalah-masalah di kelas tidak mungkin diselesaikan dalam satu waktu. Namun jika peneliti merasa mampu memecahkan seluruh permasalahan hasil identifikasi dengan suatu tindakan yang mendasari solusi permasalahan, maka dalam kaidah penelitian PTK hal ini masih dibenarkan. Oleh karena itu, analisis masalah dari permasalahan di atas di berikan dua contoh.

Alternatif 1 Analisis Masalah

Misal masalah yang dipilih Bu Ida adalah hasil belajar, $\mathrm{Bu}$ ida perlu melakukan refleksi diri "mengapa siswa saya hasil belajarnya rendah" termasuk juga dokumen-dokumen pendukung terkait. Hasil analisis didapat:

a) $\mathrm{Bu}$ Ida merasa pembelajaran yang dilakukan meski berkali-kali dirubah, masih belum menyentuh permasalahan sesungguhnya. Langkah-langkah pembelajaran belum sesuai teori sehingga tidak benarbenar mengarah ke student center learning.

b) Selama pembelajaran, Bu Ida tidak menggunakan Lembar Kerja sebagai bahan ajar yang mewakili strategi pembelajaran. Bahan ajar yang digunakan hanya 
berorientasi pada buku pegangan siswa (text book oriented).

c) Dari daftar hadir siswa, kesimpulannya 5\% siswa setiap harinya dalam 2 bulan terakir tidak hadir di kelas tanpa ijin.

d) Nilai siswa pada topic pecahan terkait (operasi penjumalah, pengurangan dan perkalian pecahan) juga masih rendah, rata-rata sekitar nilai 50 .

Alternatif 2 Analisis Masalah

Misal Bu Ida ingin menyelesaikan masalah sekaligus dalam satu kali tindakan karena merasa mampu setelah membaca literatur terkait (buku, hasil penelitian terdahulu yang serupa), serta diskusi dengan guru matapelajaran matematika lainnya.Bu Ida memandang masalah respon, hasil belajar, dan aktivitas adalah masalah umum yang terjadi pada mata pelajaran matematika di sekolah manapun. Masalah pemahaman soal, perencanaan solusi dan pelaksanaannya, dan ketidaktelitian siswa menjadi masalah yang lebih spesifik. Apabila dicarikan model pembelajaran yang tepat, maka akan dapat menyelesaikan seluruh permasalahan yang ada.

b. Merumuskan Tindakan dan Merumuskan Masalah

Berdasar hasil identidikasi dan analisis masalah diperoleh dua hasil alternatif analisis. Pada bagian ini, penulis akan mendeskripsikan rumusan tindakan, hanya 
pada alternatif ke-2 (rumusan tindakan dan rumusan masalah pertama diserahkan kepada pembaca sebagai latihan).Setelah melakukan refleksi, berdiskusi dengan guru matematika lain, membaca buku dan jurnal penelitian terkait model pemecahan masalah matematika. Bu Ida berpikir aktivitas belajar siswa menjadi prioritas masalah, namun semua masalah yang adaesensinya adalah kemampuan siswa dalam menyelesaikan soal (masalah) yang kurang atau selama ini yang dikenal kemampuan pemecahan masalah. Melalui model pemecahan masalah selain siswa dilatih memahami masalah sampai pada melatih ketelitian siswa dalam menjawab soal.Model ini juga mengaktifkan siswa dan mengkonstruksi pemahaman siswa dari masalah matematika yang diberikan sehingga siswa tidak merasa hafalan rumus dan sekaligus diharapkan respon siswa menjadi positif.

Jadi tindakan yang diambil bu Ida adalah menerapakan model pembelajaran berbasis masalah, sementara masalah yang akan diselesaikan adalah aktivitas belajar siswa.

Rumusan masalah suatu penelitian hendaknya dijelaskan secara jelas, spesifik, operasional, dalam bentuk kalimat Tanya, dan jika dimungkinkan diperinci agar lebih mudah dianalisis dan dipecahkan. Rumusan masalah yang dapat dibuat dari alternatif masalah ke 2 sebelumnya 
adalah "bagaimana meningkatkan aktivitas belajar siswa melalui model pembelajaran berdasarkan masalah?". Adapun rumusan masalah yang lebih rinci, misal:

1) Bagaimana bentuk lembar kerja siswa yang berorientasi problem solving (pemecahan masalah) untuk meningkatkan aktivitas siswa?

2) Bagaimana kaitan hasil belajar siswa dengan aktivitas siswa?

3) Bagaimana kaitan pemecahan masalah dengan aktivitas siswa?

4) Bagaimana kaitan respon siswa dengan aktivitas siswa?

c. Merumuskan Hipotesis Tindakan

Pada langkah ini dilakukan refleksi kembali apakah peneliti mampu melanjutkan PTK yang sesuai dengan rumusan masalah dan teori-teori relevan beserta hasil penelitian terdahulu. Jika sudah diyakini, maka peneliti dapat mengajukan hipotesis tindakan. Contoh hipotesis tindakan menggunakan masalah sebelumnya adalah "model pembelajaran berdasarkan masalah dapat meningkatkan aktivitas siswa".

d. Mempersiapkan dan Melaksanakan Tindakan

Mempersiapkan penelitian menjadi langkah penting yang harus dilakukan peneliti, bisa dibilang kesuksesan sebuah PTK sangat tergantung pada persiapan peneliti dalam menghadapi penelitian. Kesiapan ini sangat berguna 
untuk mengumpulkan data sampai ada melaksanakan PTK dan membuat laporan penelitian. Hal yang harus disiapkan peneliti diantaranya perangkat dan instrumen penelitian, sarana dan prasana (misal media jika diperlukan), koordinasi dengan tim peneliti (jika penelitian dilakukan tidak sendiri), merumuskan indikator keberhasilan sesuai data yang akan diambil, menyiapkan teknik pengumpulan data dan cara analisis data sesuai dengan indikator keberhasilan. Jika memang dirasa perlu hendaknya melakukan simulasi tindakan agar hipotesis tindakan dapat tercapai.

Langkah berikutnya adalah melaksanakan tindakan, pelaksanakaan tindakan dapat dilakukan dengan memilih model PTK yang sudah dibahas pada sub bab sebelumnya. Prinsip penelitian PTK yang tidak boleh dilupakan oleh pendidik adalah mengajar sambil meneliti. Jadi jangan sampai pelaksanaan PTK mengganggu rencana pembelajaran yang disusun, atau sebaliknya jangan sampai pembelajaran tanpa evaluasi dan tindakan melalui PTK.

\section{E. Contoh Penyusunan dan Laporan PTK}

Penyusunan Laporan PTK umumnya mengikuti sistematika laporan PTK seperti di bawah ini: 


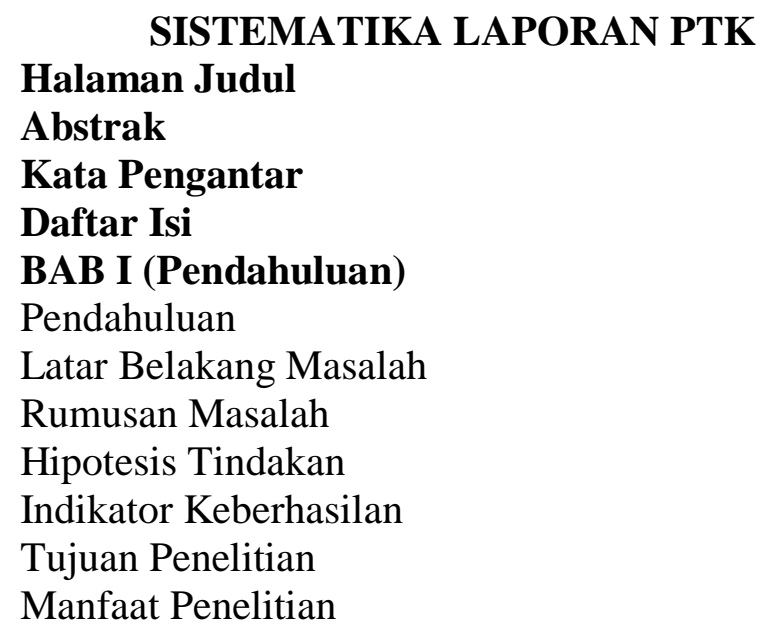

Penulis dalam hal ini sebagai dosen di LPTK Perguruan

Tinggi tepatnya di prodi PGSD, pernah melakukan Penelitian Tindakan Kelas di kelas yang diampu tahun 2016 pada 
matakuliah Konsep Dasar Matematika. Contoh Penyusunan dan Laporan PTK, penulis berikan sesuai dengan penelitian penulis tersebut.

\section{Judul Penelitian}

Penentuan judul penelitian sebetulnya bukan merupakan langkah pertama dalam melakukan PTK, namun setelah serangkaian observasi, identifikasi sampai pada menyusun rumusan hipotesis tindakan, barulah judul penelitian dapat ditentukan. Judul harus memuat analogi "penyakit - obat pasien - rumah sakit". Inovatif, singkat (maksimal 15 kata), spesifik, dan jelas. Umumnya mengikuti dua formula judul seperti di bawah ini.

Formula 1:

Peningkatan ...(penyakit)... Melalui ... (obat)... pada...(pasien)... di... (rumah sakit)

Judul:

Peningkatan Hasil Belajar Melalui Penerapan Pengajaran Terbalik pada Mahasiswa PGSD di Kelas A-2 Universitas Muhammadiyah Sidoarjo

Formula 2:

Penerapan ...(obat)... untuk Meningkatkan ...(penyakit)... (pasien)... di ... (rumah sakit)

Judul: 
Penerapan Pengajaran Terbalik untuk Meningkatkan Hasil Belajar Mahasiswa PGSD Universitas Muhammadiyah Sidoarjo Pada MataKuliah Konsep Dasar Matematika

\section{Latar Belakang}

Latar belakang menguraikan masalah, tindakan, dan inovasi tindakan (jika ada). Isi latar belakang mencakup bagaimana seharusnya situasi ideal (harapan) dan menjelaskan kenyataan terjadi di kelas dengan mengkaitkan situasi pada umunya (kenyataan). Hasil observasi berupa identifikasi masalah yang diangkat beserta analisis masalah dijelaskan pula sehingga pembaca mengetahui fokus permasalahan dan tindakan yang diambil apakah tepat sesuai dengan "kesenjangan" antara harapan dan kenyataan yang ada.

Contoh latar belakang sesuai judul penelitian di atas

Salah satu masalah pada pembelajaran matematika di lingkungan Program Studi Sekolah Dasar (PGSD) adalah rendahnya kompetensi mahasiswa calon guru sekolah dasar dalam menguasai materi-materi di tingkat sekolah dasar. Berdasarkan beberapa penelitian di Lembaga Perguruan Tinggi Keguruan (LPTK) menjelaskan permasalahan yang serupa, penelitian oleh Hapipi, dkk (2014) menunjukkan mahasiswa S1 PGSD Universitas Mataram memiliki prestasi belajar matematika yang tidak memuaskan. Marwiyanto (2012) menyatakan bahwapretasi belajar mahasiswa PGSD UNS Surakarta pada matakuliah matematika masih rendah. Hal ini 
mengisyaratkan banyak mahasiswa memiliki kompetensi yang kurang dalam memahami dan menyelesaikan soal-soal matematika di PGSD.

Padahal kompetensi mahasiswa di tingkat perguruan tinggi dipersiapkan untuk mendukung kompetensi guru dalam mengajar di sekolah dasar. Sebagaimana dalam Kerangka Kualifikasi Nasional Indonesia PGSD (2013) bahwa program studi S-1 PGSD diarahkan untuk mencetak sarjana S1 yang salah satunya memiliki keahlian sebagai Tenaga Pendidik di SD yang mampu merencanakan, melaksanakan, mengevaluasi dan mengembangkan pendidikan berdasar keilmuan, berkarakter, inovatif, dan memiliki wawasan luas yang dapat meningkatkan mutu pembelajaran di sekolah dasar

Rendahnya kompetensi mahasiswa menyebabkan banyaknya kesalahan yang dilakukan mahasiswa dalam menyelesaikan soal. Penelitian terdahulu yang dilakukan peneliti pada mahasiswa PGSD Universitas Muhammadiyah Sidoarjo semester I tahun ajaran 2015-2016 di kelas A-2 diperoleh bahwa jenis kesalahan yang dilakukan mahasiswa dalam menyelesaikan soal pertidaksamaan meliputi kesalahan konsep, prinsip, dan operasi yang relatif tinggi. Sementara faktor-faktor penyebab kesalahan tersebut adalah mahasiswa kurang memahami materi pra-syarat pertidaksamaan linier, 
mahasiswa tidak teliti dalam memahami dan menyelesaikan soal, mahasiswa malu bertanya dan mengungkapkan pendapatnya kepada dosen saat berinteraksi di kelas, mahasiswa lebih percaya diri bertanya dan mengungkapkan pendapanya kepada teman sejawatnya, mahasiswa tidak menyukai matematika pada jenjang pendidikan sebelum perguruan tinggi, mahasiswa hanya menghafal konsep atau rumus tanpa memahaminya secara bermakna, mahasiswa tidak terbiasa menyelesaikan soal-soal non rutin (Amir, 2015).

Sebenarnya akar dari masalah-masalah tersebut adalah (1) mahasiswa mengalami kesalahan konsep, prinsip, dan operasi; (2) aktivitas pembelajaran belum optimal; (3) minat belajar matematika mahasiswa rendah; (4) interaksi antar mahasiswa kurang optimal. Masalah-masalah tersebut bermuara pada rendahnya hasil belajar matematika mahasiswa pada konsep dasar matematika. Oleh sebab itu fokus masalah penelitian ini adalah hasil belajar matematika.

Masalah ini harus dicarikan sebuah solusi dalam hal ini peneliti merupakan dosen di tempat terjadinya masalah tersebut, karena dosen harus menyadari kesulitan yang dialami mahasiswa dalam belajar matematika agar mahasiswa mampu belajar secara efektif, mengembangkan dan mendesain pembelajaran dalam lingkungan sekitar mereka (Yetkin, 2003). Solusi yang dapat ditawarkan dalam pembelajaran adalah penerapan reciprocal teaching atau pengajaran terbalik. 
Menurut Nur (dalam Trianto, 2007) pada penerapan pengajaran terbalik guru memberitahukan akan memperkenalkan suatu pendekatan/strategi belajar, menjelaskan tujuan, manfaat dan prosedurnya. Selanjutnya mengawali pemodelan dengan membaca paragraf suatu bacaan. Kemudian menjelaskan dan mengajarakan bahwa pada saat atau selesai membaca terdapat kegiatan-kegiatan yang harus dilakukan. Lalu siswa memahami keterampilan di atas, guru menunjuk seorang siswa untuk menggantikan perannya dalam kelompok tersebut. Mula-mula ditunjuk siswa yang memiliki kemampuan memimpin diskusi, selanjutnya secara bergilir setiap siswa merasakan/melakukan peran sebagai guru. Setelah sesi perkenalan berakhir, guru menjelaskan kepada siswa mengapa, kapan, dan bagaimana strategi tersebut dilakukan.

Nampak bahwa pengajaran terbalik dapat menjadi sebuah solusi permasalahan yang ada karena mahasiswa dilatih secara mandiri membaca bahan bacaan atau literatur terkait materi pertidaksamaan linier sehingga dapat membantu mahasiswa sadar dan mengenali kesalahan konsep, prinsip, dan prosedural yang dilakukannya sekaligus menutupi kelemahan mereka pada materi pra syarat pertidakamaan linier melalui penyelesaian soal non rutin dan bahan ajar yang diberikan. Selain itu pengajaran terbalik menyebabkan berkurangnya dominasi dosen ke mahasiswa karena mahasiswa memiliki 
interaksi yang lebih banyak dengan temannya sendiri dalam kelompok dan tutor sebaya, sehingga aktivitas dan interaksi antar mahasiswa menjadi semakin baik dan optimal. Serta mahasiswa yang tidak memiliki minat dengan matematika, akan tertarik dengan pengajaran yang tidak cenderung didominasi oleh dosen. Apabila semua ini terjadi diharapkan akan bermuara pada meningkatnya hasil belajar matematika.

Menurut hasil penelitian Mahmudi, dkk (2006) penerapan pengajaran terbalik yang dipadu dengan pembelajaran kooperatif menyebabkan 62,5\% mahasiswa tuntas belajar. Dengan demikian apabila di dalam kelas tempat terjadi masalah diterapkan pengajaran terbalik maka dapat meningkatkan hasil belajar dan menyelesaikan masalahmasalah lain tentang aktivitas, minat belajar, interaksi serta menurunkan kesalahan (konsep, prinsip, operasi) mahasiswa.

Berdasar uraian-uraian di atas, peneliti akan melakukan penelitian tindakan

\section{Rumusan Masalah}

Secara umum rumusan masalah penelitian ini “bagaimanakan penerapan pembelajaran terbalik dapat meningkatkan hasil belajar matematika pada materi pertidaksamaan linier bagi mahasiswa di kelas A-2 semester I?". Secara lebih khusus rumusan masalah dalam penelitian ini 
adalah (1) Apakah penerapan pembelajaran terbalik dapat menurunkan jenis kesalahan konsep, prinsip, dan operasi mahasiswa? (2) Apakah penerapan pembelajaran terbalik dapat meningkatkan aktivitas mahasiswa? (3) Apakah penerapan pembelajaran terbalik dapat meningkatkan minat mahasiswa? (4) Apakah penerapan pembelajaran terbalik dapat meningkatkan interaksi mahasiswa?

\section{Hipotesis Tindakan}

Rumusan hipotesis tindakan dapat dinyatakan dalam bentuk deklaratif atau sebab akibat "jika... maka". Misal hipotesis tindakan:

Deklaratif:

"Penerapan pengajaran terbalik dapat meningkatkan Hasil belajar mahasiswa PGSD A-2 Semester I Tahun Ajaran 20152016 Universitas Muhammadiyah Sidoarjo" "Jika...maka...":

“Apabila mahasiswa belajar melalui pengajaran terbalik maka hasil belajarnya akan meningkat."

Adapun hipotesis tindakan yang lebih rinci sebagai berikut.

a. Apabila mahasiswa belajar melalui pengajaran terbalik maka kesalahan konsep, prinsip, dan operasi dalam menyelesaikan soal akan menurun.

b. Apabila mahasiswa belajar melalui pengajaran terbalik maka aktivitas belajarnya akan meningkat. 
c. Apabila mahasiswa belajar melalui pengajaran terbalik maka minat belajarnya akan meningkat.

d. Apabila mahasiswa belajar melalui pengajaran terbalik maka interaksi belajar antar mahasiswa akan meningkat.

\section{Tujuan Penelitian}

Tujuan Penelitian menggambarkan hasil penelitian yang akan dicapai dan konsisten dengan rumusan masalah.

Tujuan umum penelitian pada contoh yang dijelaskan adalah mendeskripsikan penerapan pengajaran terbalik yang dapat meningkatkan hasil belajar matematika pada materi pertidaksamaan linier bagi mahasiswa di kelas A-2 semester I. Adapun tujuan penelitian yang lebih khusus adalah

a. Mendeskripsikan penurunan kesalahan konsep, prinsip, dan operasi yang dilakukan mahasiswa.

b. Mendeskripsikan peningkatan aktivitas belajar mahasiswa.

c. Mendeskripsikan peningkatan minat belajar mahasiswa.

d. Mendeskripsikan peningkatan interaksi mahasiswa.

\section{Manfaat Penelitian}

Manfaat penelitian menggambarkan kegunaan bagi peneliti, objek yang diteliti, dan intanstansi atau lembaga peneliti maupun objek penelitian.

Manfaat penelitian di atas adalah:

a. Bagi Mahasiswa: hasil penelitian ini akan sangat bermanfaat bagi mahasiswa untuk meningkatkan hasil belajar, aktivitas, minat belajar matematika, interaksi dan 
meminimalisir kesalahan mahasiswa dalam menyelesaikan soal. Sehingga mahasiswa dapat lulus matakuliah konsep dasar matematika dan memiliki kompetensi yang memadai saat mereka lulus untuk menjadi guru sekolah dasar.

b. Bagi Dosen: menjadi bahan evaluasi pembelajaran berbasis konstruktivistik untuk menyelesaikan masalah hasil belajar, aktivitas, minat, interaksi dan kesalahan yang dilakukan oleh mahasiswa. Sehingga dapat mencetak calon guru PGSD yang memiliki kompetensi sesuai dengan visi dan misi asosiasi dosen PGSD.

c. Bagi UMSIDA: Penelitian ini bermanfaat sebagai sumber dan data guna meningkatkan pembelajaran di FKIP khususnya di PGSD, sehingga dapat menunjang visi dan misi UMSIDA yakni mutu perguruan tinggi tahun 2020.

\section{Definisi Istilah}

Definisi istilah merupakan kumpulan penjelasan katakata kunci penelitian, penjelasan ini didasarkan atas kajian teori tertentu. Pada penelitian di atas, definisinya sebagai berikut.

a. Pengajaran terbalik adalah pengajaran yang menekankan pada proses perangkuman, pengajuan pertanyaan, pengklarifikasian dan prediksi oleh mahasiswa dari tugas yang diberikan oleh dosen yang selanjutnya secara perlahan mahasiswa yang ditunjuk sebagai tutor sebaya menggantikan peran dosen dalam kelompoknya. 
b. Hasil belajar adalah kemampuan-kemampuan yang dimiliki siswa setelah ia menerima pengalaman belajaranya berupa kemampuan dalam menguasai isi pelajaran matematika yang diuji melalui tes. Tes yang diberikan berupa soal essay yang diukur meliputi aspek pemahaman (C2), aspek penerapan (C3), aspek analisis (C4) dan aspek evaluasi (C6).

\section{Kajian Pustaka (BAB II)}

Kajian pustaka berisi penjelasan deskriptif kata kunci penelitian dari berbagai referensi yang sesuai (bisa dari buku atau hasil penelitian). Kajian mengenai teori, temuan dan bahan penelitian lain dijadikan alasan untuk menggambarkan ketepatan tindakan yang diambil untuk mengatasi masalah. Pada kajian pustaka bisa juga diuraikan kerangka berpikir penelitian.

Kajian pustaka pada contoh sebelumnya berisi penjelasan topik mengenai pengajaran terbalik dan hasil belajar.

\section{Jenis Penelitian}

Jenis penelitian menguraikan garis besar PTK yang akan dilakukan beserta model PTK yang akan digunakan.Pada contoh sebelumnya, uraian bagian jenis penelitiannya adalah:

Penelitian ini dirancang menggunakan penelitian tindakan kelas. Menurut Siswono (2008) penelitian tindakan kelas merupakan salah satu jenis penelitian yang berupaya memecahkan masalah-masalah yang dihadapi pengajar atau 
pendidik (guru atau dosen) yang berkaitan dengan proses pembelajaran di kelasnya sendiri. Penelitian ini menggunakan model PTK oleh Kemmis \& McTaggart yang mengembangkan model PTK oleh Kurt Lewin yang memiliki komponen pokok PTK yakni perencanaan (planing), tindakan (acting), pengamatan (observing), refleksi (reflecting).

\section{Waktu,Tempat dan Penelitian}

Uraian waktu, tempat dan penelitian pada contoh sebelumnya adalah:

penelitian ini adalah mahasiswa S-1 PGSD Universitas Muhammadiyah Sidoarjo. penelitian ini adalah mahasiswa semester I tahun ajaran 2015-2016 di kelas A-2 sebanyak 37 mahasiswa.

\section{Teknik, Instrumen, dan Pengumpulan Data}

Teknik, Instrumen, dan pengumpulan data menjelaskan data apa saja yang akan dikumpulkan, bagaimana cara pengumpulan data, dan bagaimana mengukur data tersebut. teknik pengumpulan data bisa berupa observasi, wawancara, kuesioner, dokumenter, metode tes dan metode skala.

Secara umum pengumpulan data Pada contoh sebelumnya. menggunakan tes, observasi, dokumentasi proses dan hasil tindakan. Adapun rincian teknik pengumpulan data sebagai berikut.

a. Data skor hasil belajar dan prosentase jenis kesalahan yang dilakukan mahasiswa diambil dari penilaian tes hasil belajar. 
b. Data tentang proses aktivitas, minat, dan interaksi mahasiswa serta kesesuaian scenario dalam proses pembelajaran dengan menggunakan observasi dan handycam.

c. Data tentang minat belajar mahasiswa setelah pembelejaran diperoleh dari pemberian angket setelah pelaksanaan tindakan.

d. Data tentang evaluasi-refeksi diri serta perubahan yang terjadi di kelas diambil dari jurnal yang diisi oleh dosen.

Instrumen yang digunakan dalam penelitian ini untuk mengumpulkan data adalah tes hasil belajar; rubrik penskoran; lembar observasi aktivitas minat, interaksi mahasiswa; lembar angket minat belajar; lembar jurnal reflektif; dan Rancangan Program Pembelajaran

\section{Prosedur Penelitian}

Adapun penjelasan prosedur penelitiannya prosedur penelitian tindakan kelas yang dilakukan peneliti.

a. Perencanaan

Adapun kegiatan yang dilakukan dalam tahap ini adalah

a) Merekonstruksi Rencana Pembelajaran Semester dan Rancangan Program Pembelajaran; membuat Lembar Kerja Siswa yang sesuai dengan langkah-langkah pengajaran terbalik termasuk memvalidasinya. 
b) Membuat lembar observasi untuk mengetahui aktivitas, minat, dan interaksi mahasiswa selama proses pembelajaran.

c) Membuat angket untuk mengetahui minat belajar mahasiswa setelah akhir pembelajaran.

d) Membuat tes hasil belajar dan lembar penilaian untuk mengetahui hasil belajar dan jenis kesalahan mahasiswa setelah diterapkan pembelajaran menggunakan pengajaran terbalik.

b. Pelaksanaan

Pada kegiatan ini yaitu melaksanakan skenario pembelajaran yang telah direncanakan dalam Rancangan Program Pembelajaran. Pelaksanaan tindakan dalam penelitian ini dilakukan oleh peneliti sendiri selaku dosen pengampu matakuliah.

c. Observasi

Pada kegiatan ini dilaksanakan proses observasi selama proses perkuliahan dengan menggunakan lembar observasi untuk mengetahui aktivitas, minat, dan interaksi mahasiswa.

d. Refleksi

Hasil yang didapat dalam tahap observasi dikumpulkan dan dianalisis, serta dilakukan analisis dari data tes hasil belajar dan angket minat. Selain itu digunakan jurnal reflektif yang diisi oleh mahasiswa terhadap proses pembelajaran. Semua hasil yang didapat lalu ditriangulasikan dan disesuaikan 
dengan indikator keberhasilan sebagai acuan untuk melanjutkan pelaksanaan siklus berikutnya.

\section{Teknik Analisis Data}

Data penelitian contoh PTK dianalisis secara deskriptif kuantitatif-kualitatif. Data skor hasil belajar dan prosentase jenis kesalahan dianalisis kebenarannya berdasar pedoman penskoran. Data skor aktivitas dan minat belajar mahasiswa dianalisis secara kualitatif menggunakan prosedur reduksi, penyajian, dan simpulan.

\section{Hasil Penelitian dan Pembahasan}

Secara keseluruhan dalam penelitian ini dilakukan 2 siklus masing-masing siklus dilakukan dalam 1 pertemuan.

\section{Siklus I}

a. Perencanaan

Perencanaan tindakan disusun meliputi pembuatan instrumen penelitian yakni (1) tes hasil belajar pertidaksamaan; (2) rubrik penskoran; (3) lembar observasi aktivitas, minat, interaksi mahasiswa; (4) lembar jurnal reflektif; (5) merekonstruksi perangkat pembelajaran (Rencana Pembelajaran Semester dan Rancangan Program Pembelajaran) yang sesuai dengan pengajaran terbalik (6) lembar tes diagnostik untuk mengetahui hasil belajar dan jenis kesalahan awal mahasiswa pada materi pertidaksamaan. Untuk lembar tes diagnostik diadopsi dari 
penelitian sebelumnya peneliti pada materi pertidaksamaan (Amir, 2015)

b. Pelaksanaan

Pelaksanaan penelitian dimulai dengan:

a) Menganalisa tes diagnostik (Amir, 2015), tes ini diberikan peneliti hari Rabu tanggal 7 Oktober 2015 yang dikerjakan mahasiswa selama 60 menit serta diikuti oleh 37 mahasiswa.

b) Pertemuan pertama dilakukan Rabu tanggal 14 Oktober 2015 selama 2 SKS atau 100 menit. Dalam pertemuan tersebut dikumpulkan data mengenai hasil belajar dan jenis kesalahan pada pertemuan pertama setelah diterapkan pengajaran terbalik. Diperoleh juga data tentang proses aktivitas, minat, dan interaksi mahasiswa serta kesesuaian skenario dalam proses pembelajaran menggunakan lembar observasi dan handycam. Setelahnya dilakukan evaluasi-refeksi diri serta perubahan yang terjadi di kelas yang diambil dari jurnal yang diisi oleh dosen.

c. Pengamatan

Pada tahap ini dilaksanakan proses observasi terhadap pelaksanaan tindakan dengan menggunakan lembar observasi yang telah dibuat dan mengadakan penilaian untuk mengetahui jenis kesalahan sekaligus hasil belajar mahasiswa. 
a) Hasil tes diagnostik awal mengenai jenis kesalahan dan hasil belajar. Dari 37 mahasiswa diperoleh persentase jenis kesalahan mahasiswa adalah kesalahan konsep 40,67\%, kesalahan prinsip 35,75\%, kesalahan operasi 25,5\%. Persentase kesalahan mahasiswa cukup tinggi karena memiliki masing-masing persentase kesalahan di atas $15 \%$. Dari hasil tes diagnostik tersebut dianalisis hasil belajar mahasiswa, didapatkan bahwa mahasiswa menjawab dengan benar mencapai $45 \%$.

b) Hasil tes untuk mengetahui jenis kesalahan dan hasil. Dari 37 mahasiswa diperoleh kesalahan konsep 20\%, kesalahan prinsip 25\%, kesalahan operasi $17,5 \%$. Persentase kesalahan mahasiswa masing-masing memiliki persentase kesalahan di atas $15 \%$, rata-rata persentase kesalahan mahasiswa $20,8 \%$. Dari hasil di atas dianalisis hasil belajar mahasiswa berdasarkan katergori jawaban benar, salah, dan tidak menjawab. Didapatkan bahwa hasil belajar mahasiswa mencapai $65 \%$ menjawab benar.

c) Hasil observasi aktivitas, minat, interaksi mahasiswa selama proses pembelajaran, diperoleh bahwa aktivitas belajar mahasiswa mencapai skor 2,8 atau sekitar 70,8\% dari skor maksimal yang diharapkan, minat belajar mencapai 2,5 atau sekitar 62,3\% dari skor maksimal yang 
diharapkan, interaksi mahasiswa mencapai skor 3 atau sekitar $75 \%$ dari skor maksimal yang diharapkan.

d. Refleksi

Berdasarkan hasil analisis dari pengamatan pada siklus pertama didapatkan hasil sebagai berikut.

a) Aktivitas dan interaksi mahasiswa tergolong baik karena 70\% mahasiswa aktif dan interaktif, akan tetapi minat mahasiswa masih di bawah 70\%. Berdasarkan jurnal penelitian yang diisi oleh peneliti, hal ini disebabkan karena aktivitas dan interaksi antar mahasiswa demikian karena mahasiswa masih melakukan penyesuaian dengan pengajaran terbalik. Namun sebetulnya mahasiswa memiliki minat dengan pengajaran terbalik dan konsep dasar matematika.

b) Persentase kesalahan mahasiswa pada tes hasil belajar memiliki masing-masing memiliki persentase kesalahan di atas $15 \%$. Harusnya persentase kesalahan mahasiswa di bawah $15 \%$. Akan tetapi hasil ini lebih baik dibandingkan dengan hasil tes diagnostik awal.

c) Persentase jawaban benar mahasiswa didapatkan bahwa nilai hasil belajar mahasiswa mencapai $65 \%$ menjawab benar. Hasil ini lebih baik dari tes diagnostic awal. Akan tetapi hasil belajar belum mencapai $70 \%$ mahasiswa menjawab benar. 
d) Berdasarkan jurnal penelitian oleh peneliti dan catatan pengamatan oleh pengamat bahwa ada beberapa mahasiswa yang tidak terlihat aktif karena pembagian kelompok yang tidak merata. Dalam kelompok tersebut ternyata rata-rata kelompok tersebut terkategori sedang sehingga tidak ada figur dalam kelompok yang dapat menjadi tutor sebaya dengan baik.

\section{Siklus II}

a. Perencanaan

Sesuai dengan hasil refleksi maka dilakukan perubahanperubahan pada pertemuan tanggal 21 Oktober 2015 yakni membagi kelompok dengan lebih merata dengan menempatkan mahasiswa berkemampuan tinggi yang tepat pada masing-masing kelompok sebagai tutor sebaya.

b. Pelaksanaan

Pertemuan kedua dilakukan Rabu tanggal 21 Oktober 2015 selama 2 SKS atau 100 menit. Dalam pertemuan tersebut dikumpulkan data mengenai hasil belajar dan jenis kesalahan pada pertemuan kedua setelah diterapkan pengajaran terbalik. Diperoleh juga data tentang proses aktivitas, minat, dan interaksi mahasiswa serta kesesuaian skenario dalam proses pembelajaran menggunakan lembar observasi dan handycam. Setelahnya dilakukan evaluasirefeksi diri serta perubahan yang terjadi di kelas yang diambil dari jurnal reflektif. 
c. Pengamatan

a) Hasil tes untuk mengetahui jenis kesalahan dan hasil. Dari 37 mahasiswa diperoleh kesalahan konsep 10\%, kesalahan prinsip 9,5\%, kesalahan operasi $5 \%$. Persentase kesalahan mahasiswa masing-masing memiliki persentase kesalahan di bawah $15 \%$ yakni $11 \%$. Dari hasil di atas dianalisis hasil belajar mahasiswa berdasarkan katergori jawaban benar, salah, dan tidak menjawab. Didapatkan bahwa hasil belajar mahasiswa mencapai 91\% menjawab benar. Hasil ini lebih baik dari tes pada siklus I. Dalam hal ini hasil belajar sudah mencapai $70 \%$ mahasiswa menjawab benar.

b) Hasil observasi aktivitas, minat, interaksi mahasiswa. Hasil observasi aktivitas, minat, interaksi mahasiswa selama proses pembelajaran, diperoleh bahwa aktivitas belajar mahasiswa mencapai skor 3,7 atau sekitar 91,7\% dari skor maksimal yang diharapkan, minat belajar mencapai 3,5 atau sekitar $87,5 \%$ dari skor maksimal yang diharapkan,interaksi mahasiswa mencapai skor 3,3 atau sekitar $83,3 \%$ dari skor maksimal yang diharapkan.

d. Refleksi

Pada siklus I dan II hasil belajar, aktivitas, interaksi, minat mengalami peningkatan, serta kesalahan mahasiswa mengalami penurunan yag dapat dilihat pada tabel berikut. 
Tabel 2. Persentase Fokus Masalah Siklus I dan Siklus II

\begin{tabular}{c|l|c|c}
\hline No & \multicolumn{1}{|c|}{ Fokus } & Siklus I & Siklus II \\
\hline 1 & Hasil Belajar & 65 & 91 \\
\hline 2 & Jenis Kesalahan (\%) & 20,83 & 11 \\
\hline 3 & Aktivitas (\%) & 70,8 & 91,7 \\
\hline 4 & Minat (\%) & 62,3 & 87,5 \\
\hline 5 & Interaksi (\%) & 75 & 83,3 \\
\hline
\end{tabular}

Siklus II pada Tabel 2 di atas sudah sesuai dengan indikator keberhasilan yakni: (1) Hasil belajar matematika mahasiswa paling tidak minimal 70\% menjawab benar. (2) Jenis kesalahan konsep, prinsip, dan operasi terjadi dibawah 15\%. (3) Praktik pembelajaran yang lebih menjadikan mahasiswa aktif. (4) Praktik pembelajaran yang lebih menumbuhkan minat belajar matematika mahasiswa. (5) Praktik pembelajaran lebih mengoptimalkan interaksi antar mahasiswa, sehingga dikatakan siklus dengan penerapan pengajaran terbalik tidak perlu dilanjutkan.

Meskipun ada beberapa penyesuaian mahasiswa dengan penerapan pengajaran terbalik, namun hal tersebut dirasa wajar karena mahasiswa tidak pernah difasilitasi dengan pengajaran terbalik. Namun permasalahan itu tidak nampak pada siklus berikutnya. Sehingga setiap aspek pada siklus I dan siklus II meningkat, kecuali untuk aspek jenis kesalahan yang memang memiliki hipotesis tindakan menurun. Hasil dari penelitian dapat digunakan referensi bagi dosen selaku peneliti untuk menerapkan pada kesempatan berikutnya. Disimpulkan 
bahwa dengan penerapan pengajaran terbalik dapat meningkatkan hasil belajar mahasiswa pada mata kuliah konsep dasar matematika. Hasil penelitian ini juga mendukung hasil penelitian oleh Mahmudi, dkk (2006) bahwa penerapan pengajaran terbalik yang dipadu dengan pembelajaran kooperatif menyebabkan 62,5\% mahasiswa tuntas belajar.

\section{Simpulan dan Saran}

\section{Simpulan}

Berdarkan hasil penelitian dan pembahasan sebelumnya, dapat disimpulkan bahwa penerapan pengajaran terbalik dapat meningkatkan hasil belajar mahasiswa kelas A-2 PGSD semester I tahun ajaran 2015-2016 Universitas Muhammadiyah Sidoarjo pada matakuliah konsep dasar matematika. Peningkatan tersebut ditandai juga dengan: (1) menurunya prosentase kesalahan konsep, prinsip, dan operasi yang dilakukan mahasiswa; (2) meningkatnya aktivitas mahasiswa; (3) meningkatnya minat mahasiswa terhadap matematika; (4) meningkatnya interaksi antar mahasiswa selama proses pembelajaran.

\section{Saran}

Berdasarkan hasil dan pembahasan, serta simpulan penelitian dapat diberikan saran bahwa:

a. Mahasiswa lebih berani mengungkapkan pendapat dan menyelesaikan masalah dalam proses pembelajaran secara lebih mandiri karena terbukti mahasiswa memiliki 
kemampuan untuk menyelesaikan soal-soal non rutin melalui diskusi dan tutor sebaya pada proses pengajaran terbalik.

b. Dosen selaku peneliti dapat menggunakan pengajaran terbalik agar pada materi berikutnya tidak ditemui masalah yang serupa sebelum penelitian tindakan kelas, sehingga dosen dapat mencetak calon guru PGSD yang lebih memiliki kompetensi sesuai dengan visi dan misi asosiasi dosen PGSD.

\section{F. Latihan Membuat PTK}

Berikut diberikan beberapa kasus permasalahan PTK yang sangat mungkin terjadi di sekolah. Pecahkan menurut pendapat anda dengan argumentasi yang logis dan ilmiah sesuai pertanyaan yang ada.

a. Pak Budi guru kelas V di sekolah dasar, sebagian siswanya sulit untuk mengikuti pelajaran dengan tenang, sebagian menyimak. Namun hasil belajar masih menunjukkan siswa "itu-itu saja" yang mendapat hasil belajar baik di atas KKM. Ada hal menarik di kelas tersebut, meski siswa sulit untuk diam, namun jika ada hal baru di kelas. Siswa antusias tertarik dan mencoba ingin tahu lebih lanjut. Perhatian itu tidak berlangsung lama jika siswa merasa bosa, biasanya dalam kurung waktu beberapa hari. 
1) Lakukan identifikasi masalah, analisis masalah, rumusan tindakan, buat rumusan masalah, rumusan hipotesis tindakan.

2) Jelaskan bagaimana persiapan dan pelaksanaan tindakan yang mungkin

b. Bu Endang guru Ilmu Pengetahuan Alam di SMP, dalam menyelesaikan soal-soal penentuan jarak, kecepatan, waktu, dan percepatan siswa berhasil dengan baik. Namun soal-soal yang menuntut siswa lebih dengan menginterpretasikan soal dalam gambar dan bobot soal ditambah, siswa merasa kesulitan. Secara umum siswa sudah berusaha dan belajar dengan semaksimal mungkin. Siswa tergolong ke dalam kelompok "melek teknologi". Aktivitas siswa masih minim untuk berdiskusi satu sama lain, seting tempat duduk masih konvensional.

1) Lakukan identifikasi masalah, analisis masalah, rumusan tindakan, buat rumusan masalah, rumusan hipotesis tindakan.

2) Jelaskan bagaimana persiapan dan pelaksanaan tindakan yang mungkin 


\section{DAFTAR PUSTAKA}

Amir, M.F. 2015. Analisis Kesalahan Mahasiswa PGSD Universitas Muhammadiyah Sidoarjo Dalam Menyelesaikan Soal Pertidaksamaan Linier. Jurnal Edukasi, Volume 1 No.2, Oktober 2015 ISSN. 2443-0455.

Ciltas Alper and tatar Enver. 2011. Diagnosing Learning Difficulties Related to the Equation and Inequality that Contain Terms with Absolute Value. International Online Journal of Educational Sciences, 3(2), 461-473.

Haryono. 1988. Penelitian tentang Kesalahan-Kesalahan dalam Memecahkan Soal-Soal Matematika Mahasiswa FPMIPA IKP Surabaya tahun Akademik 1987-1988. Surabaya: PPS IKIP Surabaya.

Kerangka Kualifikasi Nasional Indonesia PGSD. 2013. Edisi Revisi Surabaya.

Mahmudi. 2008. Implementasi Pendekatan Reciprocal Teaching (Pembelajaran Terbalik) dan Cooperative Learning (Pembelajaran Kooperatif) Pada Pembelajaran Geometri Guna Meningkatkan Hasil belajar dan Kemandirian Belajar Mahasiswa. Seminar Nasional MIPA.

Marwiyanto. 2012. Pengaruh Model Pembelajaran Kooperatif Terhadap Prestasi Belajar Pada Mahasiswa PGSD FKIP UNS Ditinjau Dari Motivasi Belajarnya. Jurnal Widya Sari, vol. 14 No 2 Mei 2012: 188-203.

Trianto. 2007. Model-model Pembelajaran Inovatif Berorientasi Konstruktivistik. Jakarta: Prestasi Pustaka. 


\section{BAB V}

\section{PENUTUP}

Berdasarkan kajian pustaka tentang metodologi penelitian dasar bidang pendidikan dapat disimpulkan:

1. Penelitian kuantitatif adalah penelitian ilmiah yang sistematis terhadap bagian-bagian dan fenomena serta hubungan-hubungannya. Tujuan penelitian kuantitatif untuk mengembangkan dan menggunakan model-model matematis (statistika), teori-teori, hipotesis, yang berkaitan dengan fenomena yang terjadi. Ciri-ciri kuantitatif meliputi teori, hipotesis, adanya perlakuan, pengamatan empiris, analisis data dengan statistika.

2. Penelitian kualitatif berangkat dari filsafat ilmu yang mencari esensi segala sesuatu. Berbeda dengan penelitian kuantitatif, yang berangkat dari asumsi adanya normalitas, dan kebenaran dicari dari rerata normalitas frekuensi atau rerata keragaman berbagai sesuatu serta mencari kebenaran lewat sampel acak atas sampel itu representatif terhadap populasinya. Pada penelitian kualitatif, mencari kebenaran melalui kasus yang menampilkan esensi yang dicari. 
3. Penelitian tindakan merupakan kajian tentang situasi sosial yang diarahkan untuk meningkatkan kualitas. Secara keseluruhan penelitian tindakan meliputi proses telaah/ analisis, diagnosis, perencanaan, pelaksanaan, monitoring, dan efek yang terkait dengan evaluasi diri dan perkembangan profesional. Penelitian tindakan merupakan bentuk refleksi diri kolektif yang dilakukan oleh para peserta dalam situasi sosial untuk meningkatkan penalaran dan keadilan. Penelitian tindakan dalam bidang pendidikan disebut sebagai Penelitian Tindakan Kelas (PTK) merupakan refleksi diri yang dilakukan oleh para partisipan (guru, siswa, dan kepala sekolah) dalam situasi pendidikan untuk memperbaiki dan meningkatkan rasionalitas dan kebenaran mengenai praktik pendidikan yang dilakukan sendiri, pengertian mengenai praktik itu sendiri, dan situasi tempat praktiknya. Jadi, PTK merupakan penelitian yang diarahkan pada adanya kesadaran diri para pengajar untuk mengevaluasi diri, merefleksi diri, dan berani bertindak dan berpikir kritis guna meningkatkan profesionalitas dalam rangka meningkatkan kualitas pendidikan. 


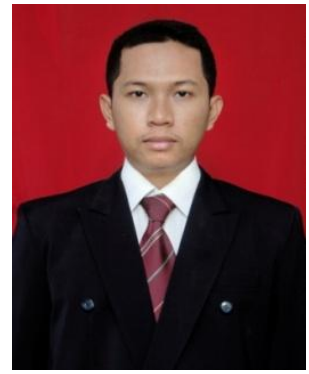

\section{BIODATA PENULIS}

Mohammad Faizal Amir, lahir di Sidoarjo, Jawa Timur pada tanggal 17 September 1989. Pendidikan S1 bidang Pendidikan Matematika ditempuh di prodi pendidikan matematika FMIPA, Universitas Negeri Surabaya, pada tahun 2007. Selanjutnya penulis menempuh pendidikan S2, juga pada prodi pendidikan matematika, Pascasarjana Universitas Negeri Surabaya, pada tahun 2011. Penulis aktif mengajar di Universitas Muhammadiyah Sidoarjo mulai tahun 2012. Penulis juga aktif melakukan tridarma, dalam bidang pengajaran, mata kuliah yang pernah diampu diantaranya adalah matematika dasar, matematika ekonomi, konsep dasar matematika, statistika dasar, dan pendidikan matematika sekolah dasar kelas tinggi. Selain itu penulis juga pernah menjadi dosen pembina ON MIPA UMSIDA bidang matematika tahun 2014 dan tahun 2015. Kegiatan pengembangan diri yang dilakukan yakni mengikuti workshop ataupun pelatihan pendidikan matematika tingkat regional ataupun nasional. Bidang keahlian khusus penelitian pendidikan matematika berorientasi HOTS pada hibah penelitian dikti atau internal Institusi dan Mandiri. Bidang pengabdian masyarakat dilakukan dengan menjadi pembicara workhsop ataupun lokakarya pendidikan, serta pernah menjadi juri dalam lomba pendidikan tingkat regional ataupun nasional.

Septi Budi Sartika, lahir di Ponorogo, 9 September 1985. Lulus Sarjana Pendidikan Fisika Universitas Negeri Surabaya tahun 2008. Penulis melanjutkan studi S2 di Prodi Pendidikan Sains Program Pascasarjana Universitas Negeri Surabaya lulus tahun 2010. Penulis saat ini masih tercatat sebagai mahasiswa program Doktor di prodi Pendidikan Sains Program Pascasarjana Universitas Negeri Surabaya. Karir pendidikan dan pengajaran dimulai tahun 2010 di Prodi Pendidikan Guru SD Universitas Muhammadiyah Sidoarjo selanjutnya tahun 2013

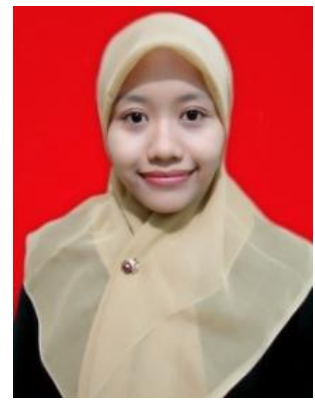
menjadi dosen tetap di Prodi Pendidikan IPA, Fakultas Keguruan dan IImu Pendidikan, Universitas Muhammadiyah Sidoarjo. Selain pendidikan dan pengajaran penulis juga terlibat dalam kegiatan penelitian dan pengabdian kepada masyarakat baik didanai oleh Ristekdikti maupun swadana. Penulis juga aktif dalam mengikuti kegiatan-kegiatan penunjang akademik seperti seminar, workshop/ lokakarya tingkat regional dan nasional, pelatihan pendidikan serta pembimbingan tugas akhir dan kegiatan akademik dan non-akademik mahasiswa. 
Buku ajar yang pernah ditulis antara Ilmu Kealaman Dasar, Modul Praktikum Fisika Dasar, Modul Praktikum Konsep Dasar IPA, Modul Praktikum Elektronika Dasar, Modul Praktikum Fluida, dan Modul Praktikum Interaksi Antar Faktor Fisik. 